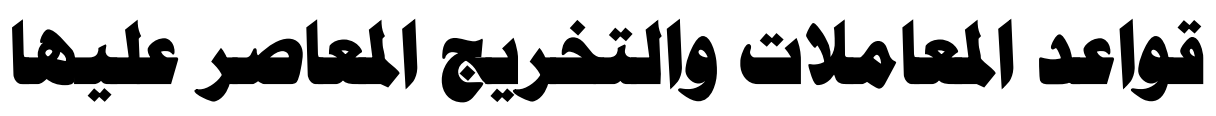 \\ Transactions rules contemporary graduation on them
}

\author{
إعداد \\ د/ لولوة بنت صالح بن حمدان الغامدي
}

أستاذ الفقه المساعد بكلية الثريعة والأنظمة جامعة الطائف Prepare

Dr. Lolwa bint Saleh bin Hamdan Al-Ghamdi 
$-1 \leqslant \leqslant \Lambda-$ 


\section{قواعد المعاملات والتخريج المعاصر عليها}

\section{لولوة بنت صالح بن حمدان الغامدي}

كلية الثريعة والأنظمة ، جامعة الطائف، المملكة العربية السعودية .

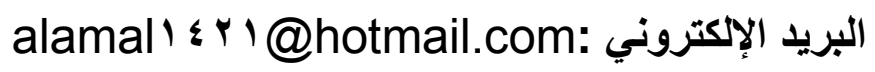

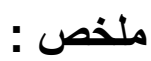

هذا البحث المسمى ( قواعد المعاملات المالية والتخريج المعاصر عليها ) تطبيق

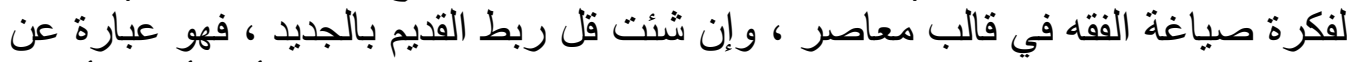

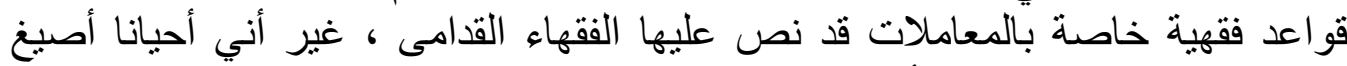

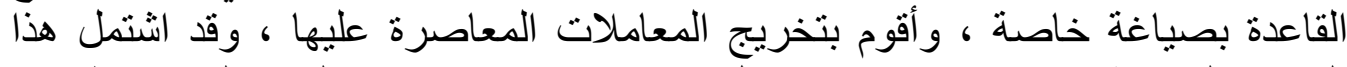

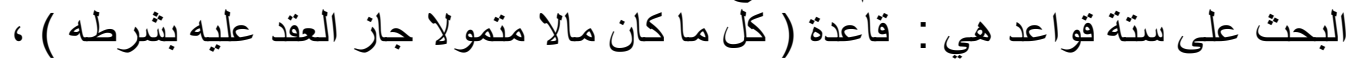

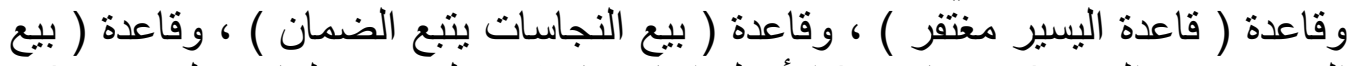

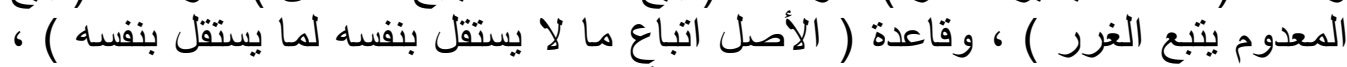

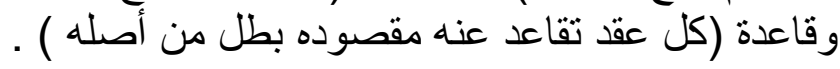

الكلمات المفتاحية: قو اعد، المعاملات، التخريج المعاصر ،المالية ،المعاملات المعاصرة. 


\section{Transactions rules contemporary graduation on them}

\section{Lolwa bint Saleh bin Hamdan Al-Ghamdi}

College of Sharia' and Regulations, Taif University, Kingdom of Saudi Arabia.

\section{E-mail : alamal Isr1@hotmail.com}

\section{Abstract:}

This research called (the rules of financial transactions and the graduation of contemporary on them) is an application of the idea formulating jurisprudence in a contemporary template and if you wish to say linking the old with the new it is a special doctrinal rules with transactions stipulated by the old jurists but sometimes, I formulate the rule, with special formulation and graduate contemporary transactions on it and this research included six rules: the rule (everything that was money financed the contract is permissible on its condition) the rule (the base of the easy forgiven), and the rule (selling impure) Follows the guarantee) the rule (selling the bad follows the ambiguity) and the rule (the principle is to follow what is not independent of himself when it is not For himself), and base (each contract he retired his intended the hero of its origin).

Keywords: rules, transactions, contemporary graduation, financial, contemporary transactions. 


\section{هقدهة}

\section{الحمد لله والصلاة والسلام على ر سلول الله :}

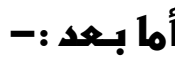

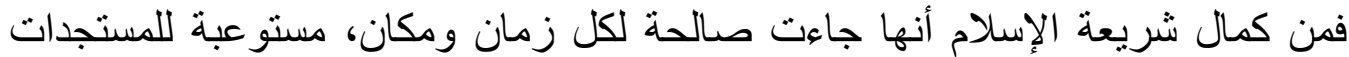

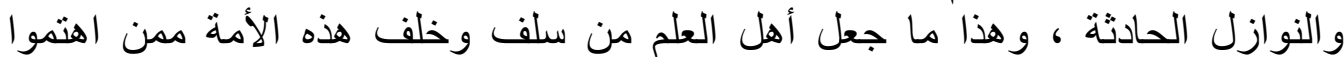

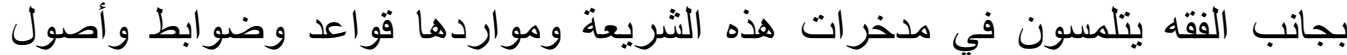

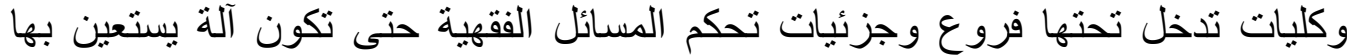

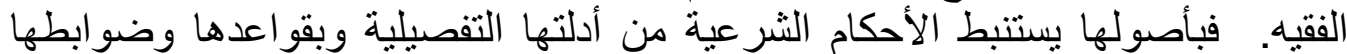

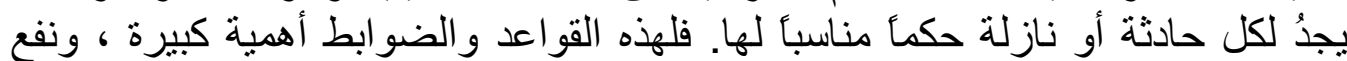

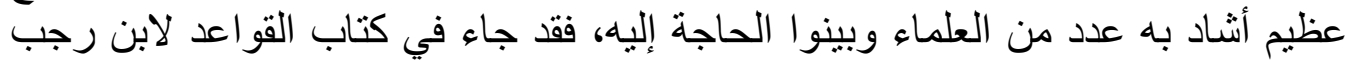

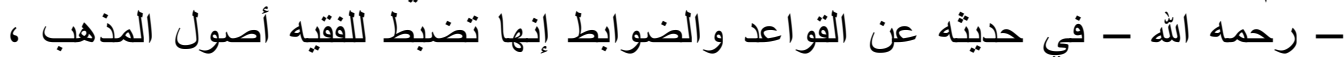

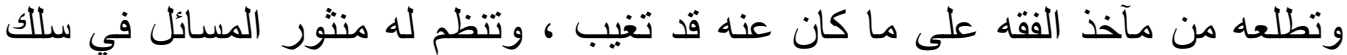

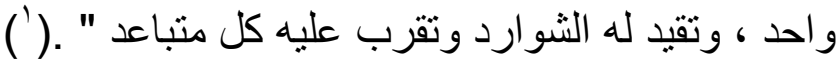

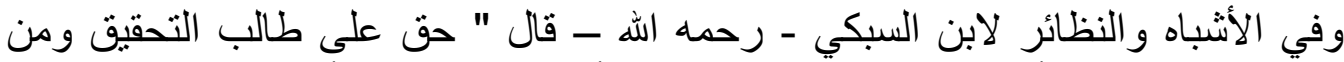

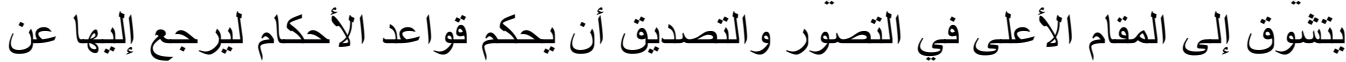

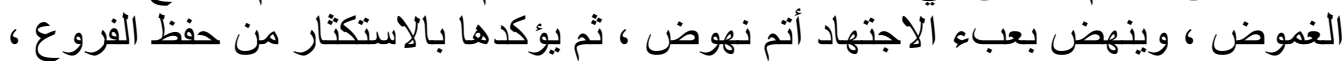

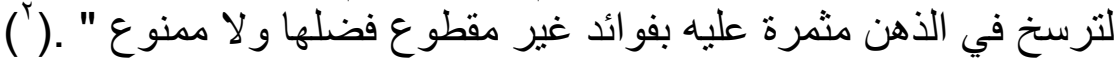

و هذا البحث المسمى " قواعد المعاملات والتخريج المعاصر عليها " يدعو إلى التجديد

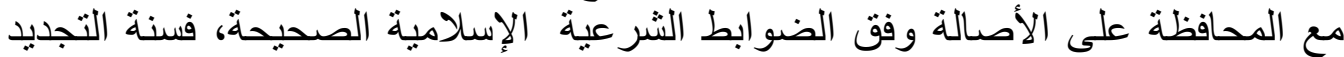

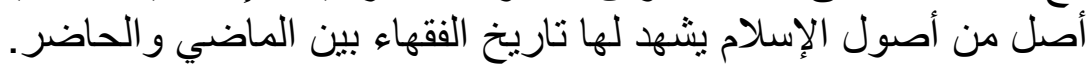

وما زال العلماء في اجتهاد مستمر، يتابع اللاحق السابق ويناقته ، وينقضه ويقيمه، وكان نبراس ذللك كله القرآن الكريم والسنة النبوية الثريفة، يدور الخلق حولهما

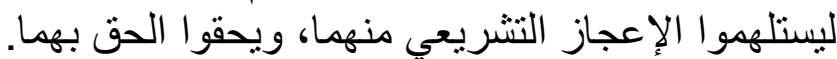

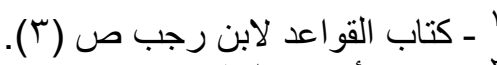




\section{منهمية البهث}

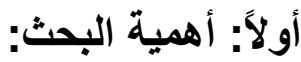

يتعرض هذا البحث لقواعد البيوع مع التخريج عليها بنماذج قديمة ومعاصرة وتكمن البهاء

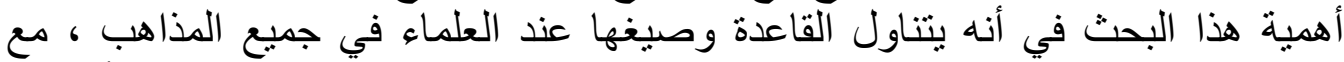

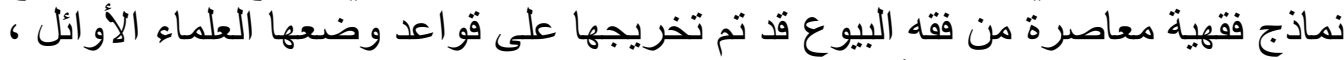
فيربط القديم بالجديد ، ويبين أن هذه الشريعة مرنة متجددة وليست متجمدة .

ثانيًا: أسباب اختيار موضوع البحث ودوافعه: 1 1 إ عدم التقليد و التعسف .

r- فقه النوازل وضرورة التجديد أمام النصوص المتناهية والحوادث غير المتناهية ، إذ وإن

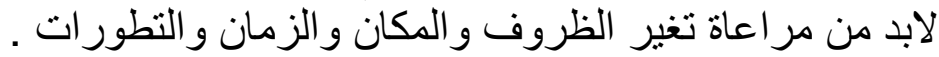

r- اتساع الهوة بين الماضي و الحاضر

فكتب الفقه المعاصرة تنقل كلام الأقدمين كما هو دون أن تبيّن المقاييس الثرعية في

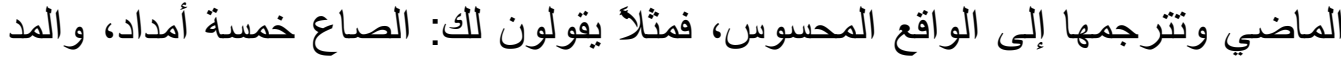

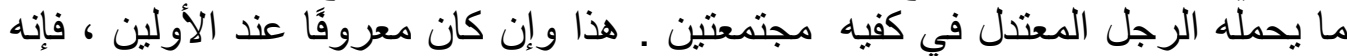
مجهول عند المعاصرين، فلابد من تحديده بوزن معرين فعروف في العصر الحالي كالجرام و المتر ، و الباوند و غير ذلك .

وسبب هذه الهوة تقصير بعض العلماء المعاصرين عن بيان المقاييس الثرعية،

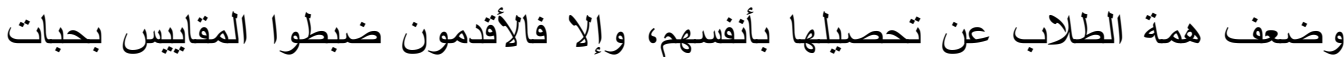

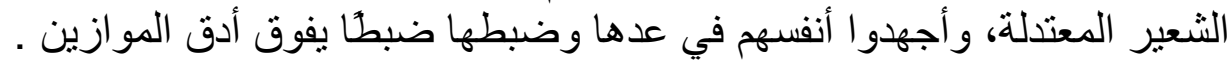

ع- ملاحظات حول الكتب الفقهية (الأسلوب و المصطلحات) الداعية للتجديد:

على الرغم من أهمية التراث الفقهي العظيم الخصب في الإسلام فهناك ملاحظات تتعلق

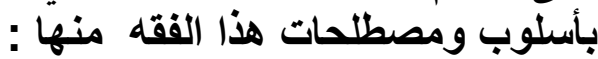

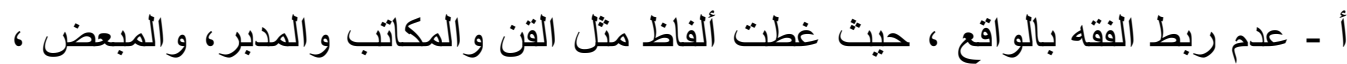

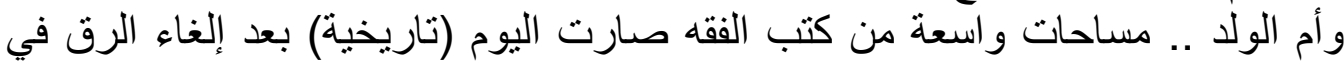

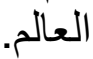

بـ - وووعورة مصطلحات الفقه الغامضة .

ج - و الإيجاز المُلغز كما في المتون، والإطناب الممل ( حاثية على حاشية على شرح). 
د - و عسر فهم الفقه و عدم تبسيطه مع عدم استخدام وسائل الإيضاح المعاصرة الممكنة

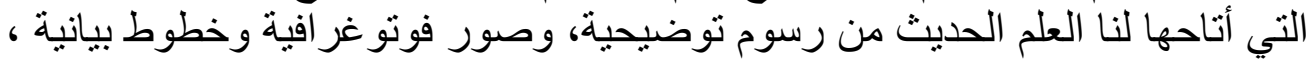

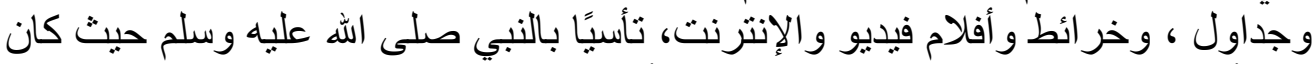

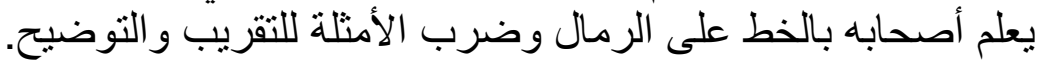

\section{ثالثًا: أهداف البحثذ:}

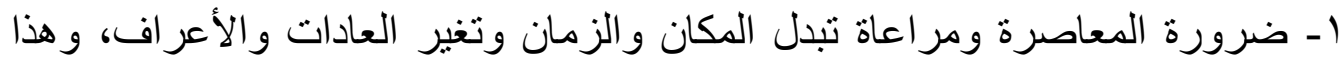

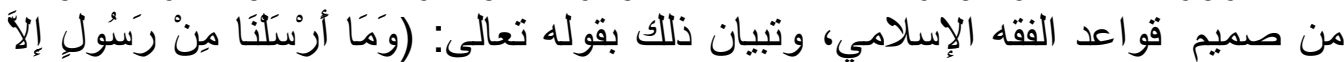

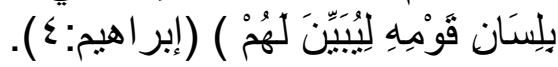

r- تبيان الحرج و التعسف في بعض الفتاوى المبنية على التحجر و الانغلاق. r- كثف جمود بعض المقلدين الآخذين بظواهر النصوص دون الوقوف وراء علل

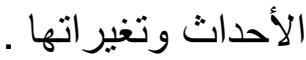

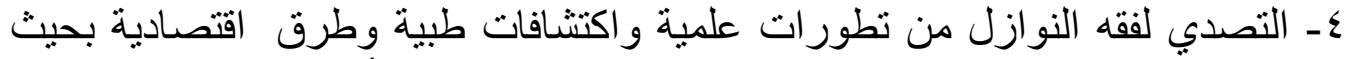

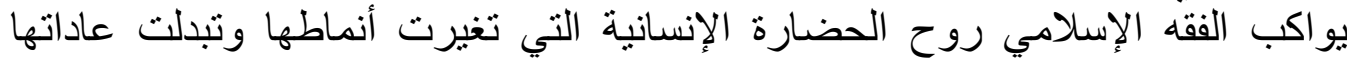

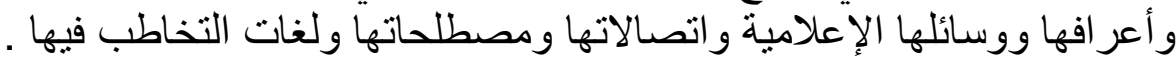

هـ مر اعاة أسلوب ومصطلحات الكتب الفقية التراثية بحيث يتم الجمع بين الأصالة

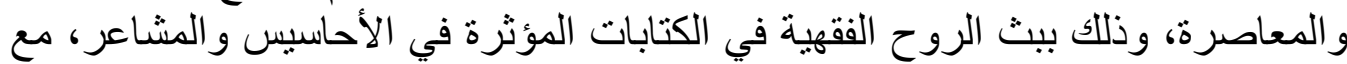

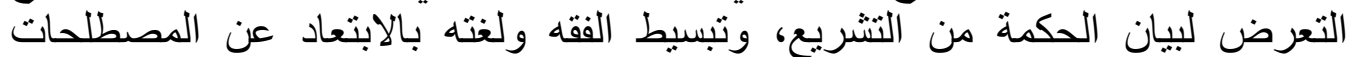

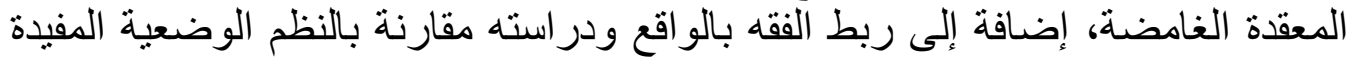

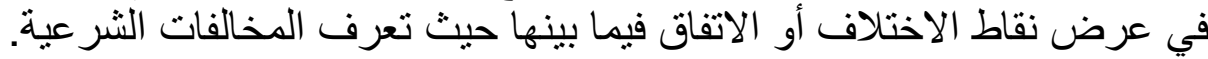
7- ضرورة ضبط لغة الخطاب الفقهي في تصريف شئون الحياة؛ إذ المرحلة الر اهنة هي

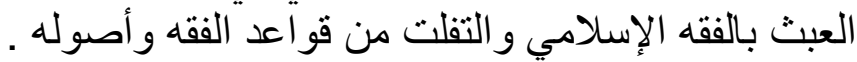

\section{الدراسات السابقةة :}

بعد البحث و التفتيش لم أجد بحثا جمع هذه القواعد التي جمعتها في بحثي وخرَّج عليها

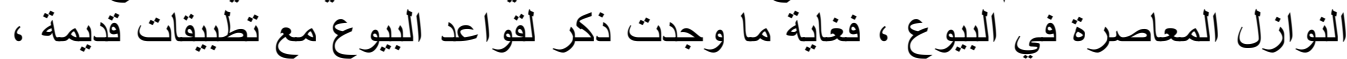

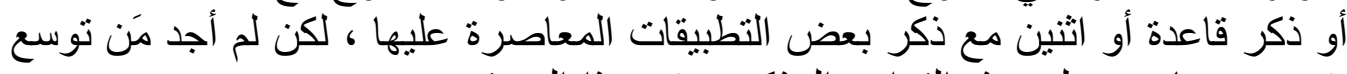
بتخريج معاصر على هذه القو اعد المذكورة في هذا البحث . 


\section{ومن الأبحاث والمصنفات والرسائل التي كتبث في قواعد البيوع ما يلى :}

1 ـ القو اعد والضوابط الفقهية عند ابن تيمية في المعاملات المالية، إبراهيم الثـال، دار

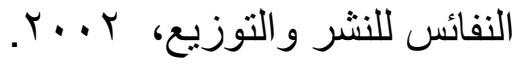

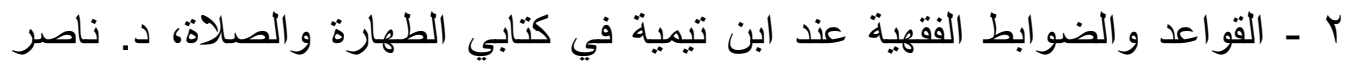

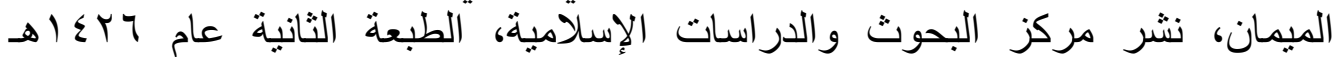

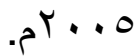

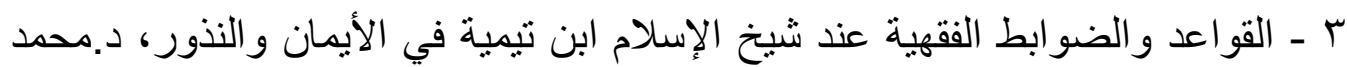

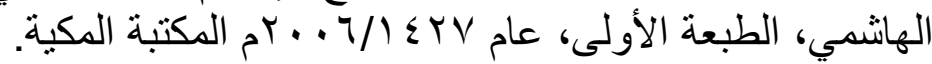

ـ ـ القو اعد و الضو ابط الفقهية لأحكام البيع في الثريعة الإسلامية، د.عبد المجيد عبد الله

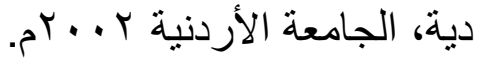

ه - قواعد البيوع وفر ائد الفروع لوليد بن راثد السعيدان ، بحث منشور على الإنترنت . 7 - موسوعة القواعد الفقهية المنظمة للمعاملات المالية الإسلامية ، للاكتور عطية

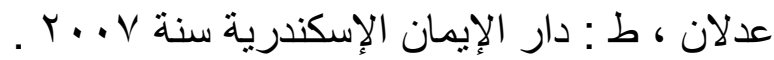

V - القو اعد الفقهية و الضوابط الثرعية للمعاملات المالية المعاصرة ، للأستاذ

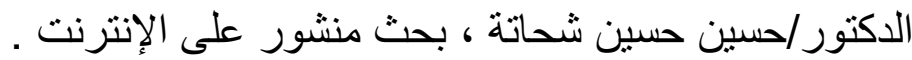

^ ـ القواعد الفقهية المتعلقة بالبيوع للأستاذ الدكتور سليمان بن سليم الله الرحيلي ، أستاذ

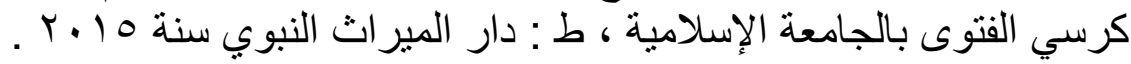

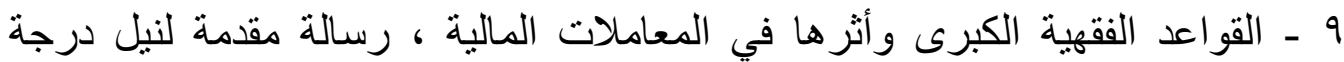

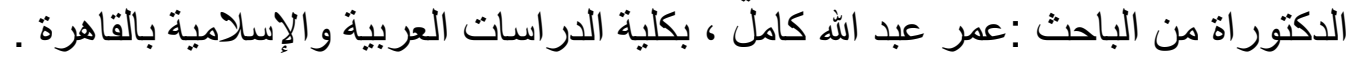

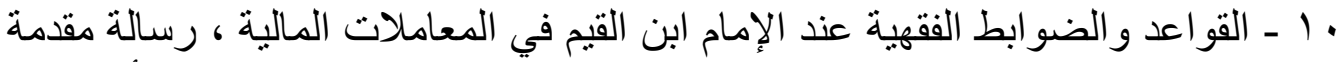

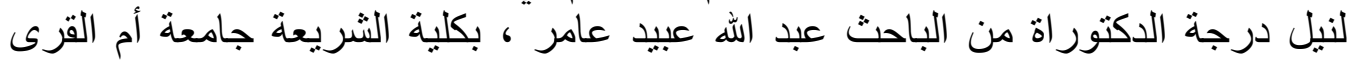

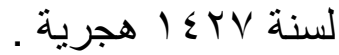

11 ـ الضو ابط و القو اعد الثر عية للمعاملات المالية الإسلامية للدكتور إسماعيل خالدي ،

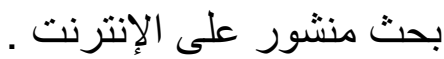

r ا ـ القواعد الحاكمة لفقه المعاملات للأستاذ الدكتور يوسف القرضاوي ، بحث منشور

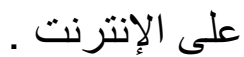




\section{رابعا : هطة البهـث :}

\section{وقد قسمت البحث إلى :}

تمهيد بعنوان : تعريف القو اعد الفقهية

المبحث الأول : القاعدة الأولى ( كل ما كان مالا متمولا جاز العقد عليه بشرطه )

المبحث الثاني : القاعدة الثانية ( قاعدة اليسير مغتفر )

المبحث الثالث : المبحث الثالث : القاعدة الثالثة : ( بيع النجاسات يتبع الضمان )

$$
\text { المبحث الرابع : القاعدة الرابعة : ( بيع المعدوم يتبع الغرر ) }
$$

المبحث الخامس : القاعدة الخامسة : ( الأصل اتباع ما لا يستقل بنفسه لما يستقل بنفسه ) المبحث السادس : القاعدة السادسة : (كل عقد تقاعد عنه مقصوده بطل من أصله ) 


\section{تمهيد \\ تعريف القواعد الفقهية \\ القواعد لغة : جمع قاعدة وهي أساس الثيء وأصله .}

فقواعد البناء أساسه الذي يعتمده ، قال الزجاج : القواعد أساطين البناء التي تعدده ومنه قوله تعالى : \} و إذ يرفع إبراهيم القو اعد من البيت و إسماعيل \{. ( ' ) ل

والقو اعد من النساء العجز اللواتي قعدن عن التصرف من أجل السن وقعدن عن الولد والمحيض. (" )

وفي الاصطلاح يطلق الفقهاء القواعد على معان منها :

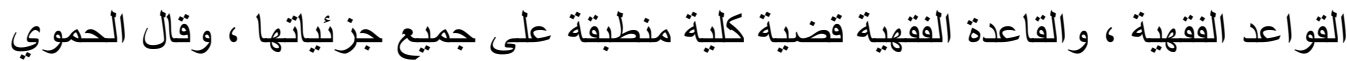

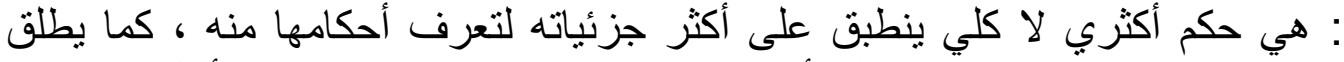

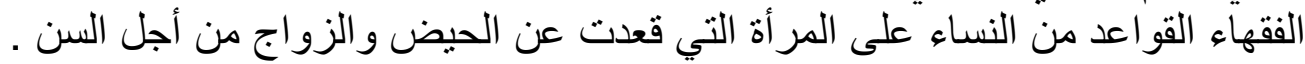

ويطلق الفقهاء قو اعد البيت على أسسه التي يقوم عليها. ( (")

\section{المبحث الأول}

\section{القاعدة الأولى ( كل ها كان مالا متسمولا جاز العقد عليه بشرطه )}

\section{المطلب الأول}

\section{صيخ القا عدة عند العلماء وبيان معناها}

من نصوص العلماء الدالة على القاعدة :

قول السرخسي : " صحة التعويض تختص بمال مُتَقََّّم ".(")

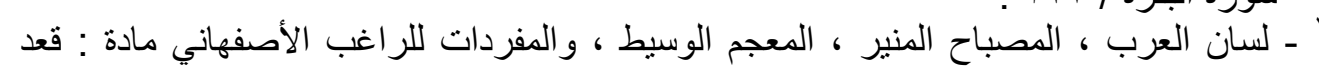

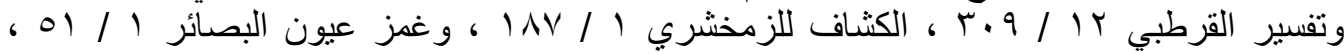

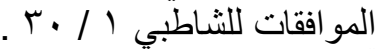

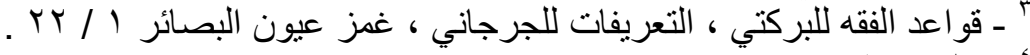




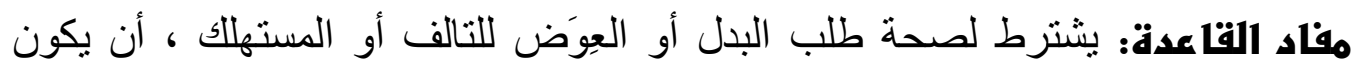

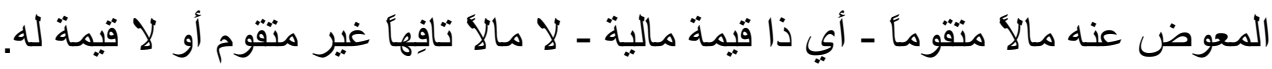

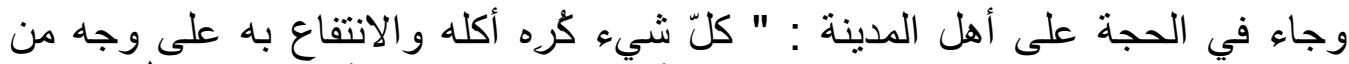
الوجوه فُشر اؤه وبيعه مكروه، وكلّ شيء لا بأس بالانتفاع به فلا بأس ببيعه ".(') وجاء في عارضة الأحوذي : " كلّ ما جاز اقتناؤه و ائنفع به صار مالأ وجاز بذل

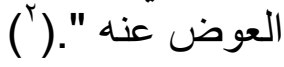
عبر الثافعية عن هذه القاعدة في كتبهم بعبارات ، منها : " الانتفاع " ، و" التقوم " ، و"

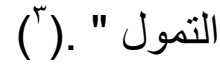

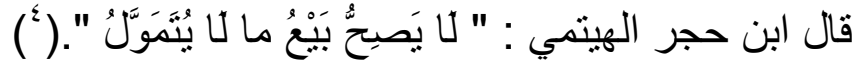 وقال الغز الي : " كل متمول معصوم مضمون "() وقال الغر اوي : قولهم : " من شروط المبيع النفع ".(")

\section{معنى القواعد السالفة والآتية :}

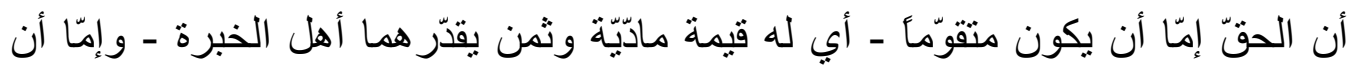

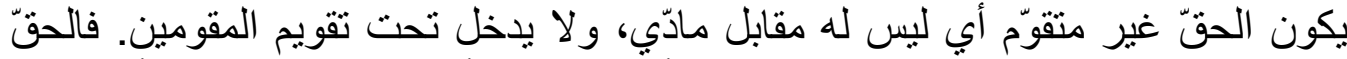

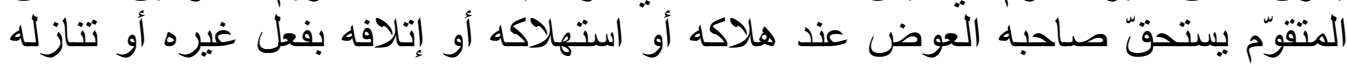

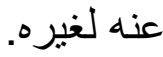

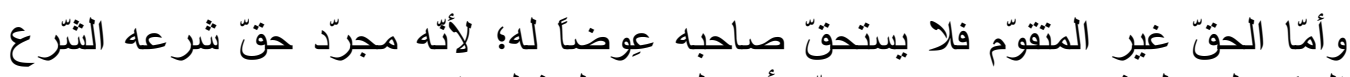
الحكيم لمصلحة من دفع ضرر متوقع أو جلب مصلحة لصناحبه.

ومن العبارات الواردة في ذللك قول السرخسي : " ما لا يتقوّم شرعأ فالجنس وغير

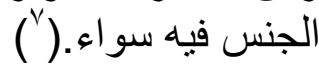

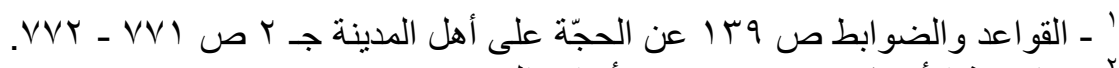

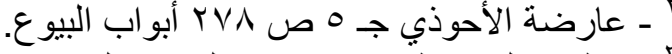

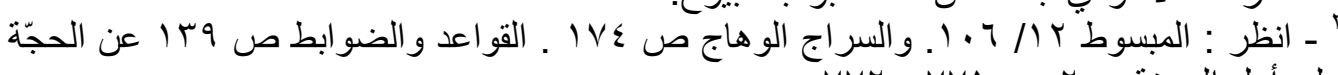

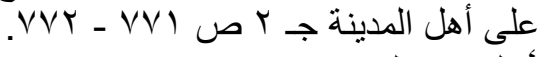
" الفتاوى الكبرى لابن حجر (T/r/T)

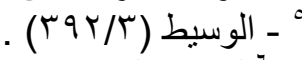




\section{معنى القا عدة السالفة:}

ما لا يتقوّم شرعاً: هو ما لم يعتبر الثّرع له قيمة أو ثمنأ كالخمر والخنزير للمسلم، والميتة عند الكلّ. وهو مأل ها لا تقطع اليد بسرقته.

وما يكون متقوّمأ شرعأ: هو ما بعتبره الثّرّع مالأ له قيمة، وتقطع اليد بسرقة ما يبلغ

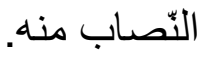

ومن العبار ات أيضا قولهم : " المثلي مضمون بمثله. و المتقوّم بالقيمة ".(')

معنم القا عدةة :

المضمونات من حيث ما تضمن به تنقسم إلى قسمين رئيسين: مثلي وقيمي. فالمنلي: هو الثنيء الذي له مثل من جنسه لا يتفاوت، فهو مضمون بمثلك إن وُجد. و القيمي: هو الثنيء الذي لا مثل له، أو له مثل متفاوت، فهذا إنّما يضمن بقيمته، أي بقدر

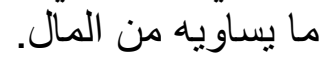

ومن القيمي أيضاً: المتلي الذي انقطع منتله فلم يوجد أو وجد متفاوتأ، فهذا يجب ضمانه بقيمته أيضنً.

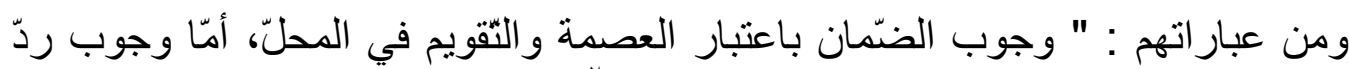

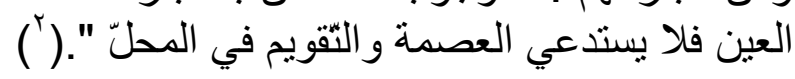

\section{معنـى القاعدةة :}

معنى وجوب الضّمان: وجوب الغر امة. و العصمة: امتناع يد الغير عنه وخلوصه لمالكه. فوجوب الغر امة منرثب على عصمة المال المضمون، وكونه متقوّما: أي ذا قيمة. وذلك

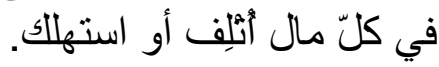

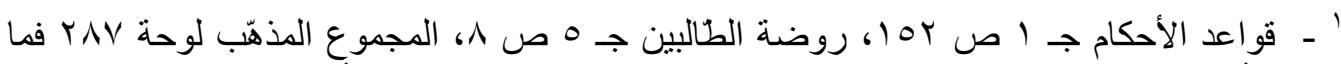

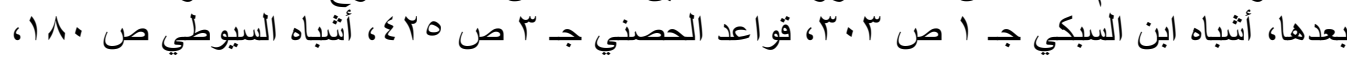

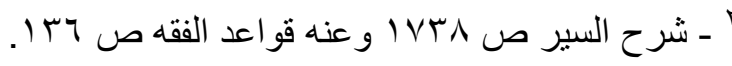




\section{المطلب الثاني}

\section{ضابط المال و المتمول ، وشروط التمول}

التمول لغة : اتخاذ المال يقال : تمول فلان إذا صار ذا مال ، وتمول : أي كثر ماله

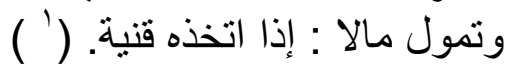

وقد جاء لفظ التمول في حديثين متفق عليهما .

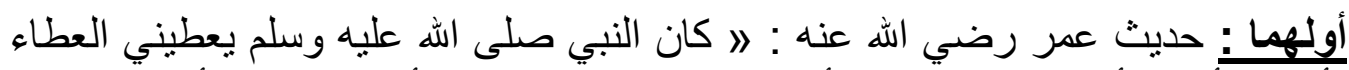

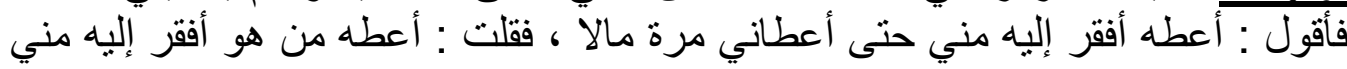

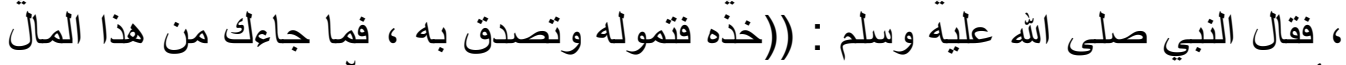

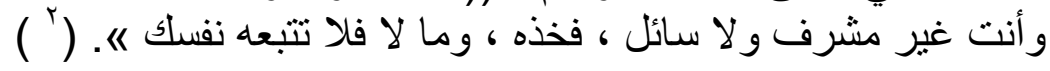

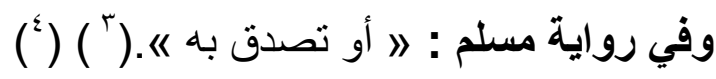

$$
\begin{aligned}
& \text { ومعنى : ((فتمول)) هنا : أي اجعله للك مالا. ( ) }
\end{aligned}
$$

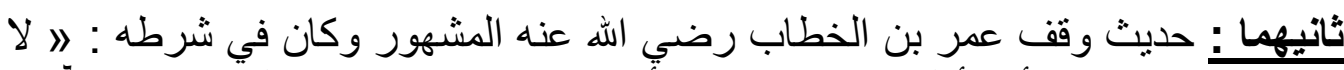

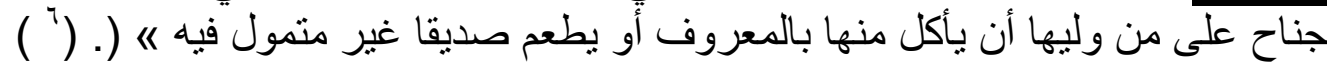

قال ابن حجر : ((" غير متمول فيه" وفي رواية الأنصاري الماضية آخر الثروط :

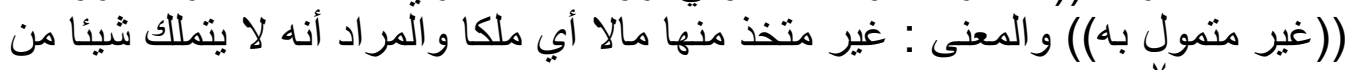

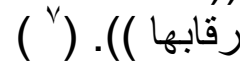
و هذا يعني أن معنى التمول في الثرع لا يخرج عن المعنى اللغوي ؛ وهو اتخاذ الثيء مالا .

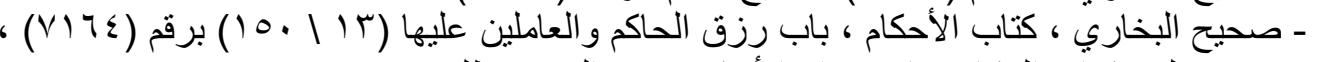

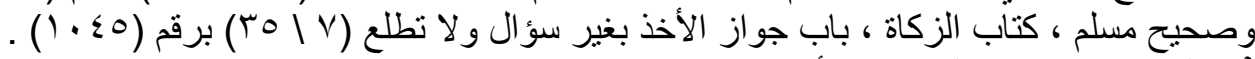

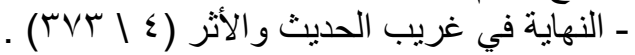

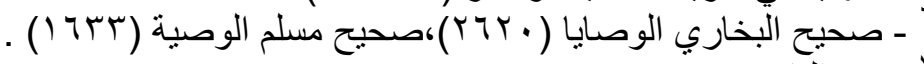




\section{أولا : ضابط المال و المتمول :}

يرد لفظ التمول كثير الدى الفقهاء وهم يقصدون به كذلك اتخاذ الثيء مالا في عرف الناس .

\section{ولألك عندهم ضابطان ينص عليهما الثافعية :}

أولهما : أن كل ما يقدر له أثر في النفع فهو متمول ، وما لا يظهر له أثر في الانتفاع

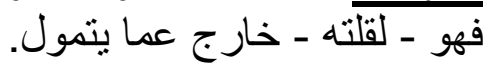

الثانى : أن المتمول هو الذي يعرض له فيمة عند غلاء الأسعار والخارج عن المتمول

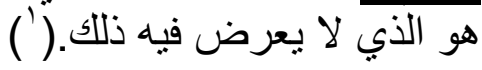

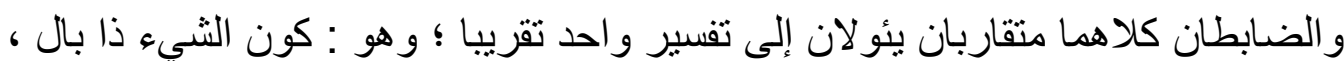

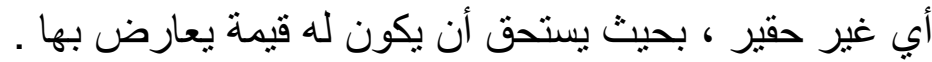
و هذا هو الذي رأيت فقهاء المذاهب يفسرون المتمول به .

قال القاضي عبد الوهاب البغدادي المالكي : (( يقطع في جميع المتمولات التي تتمول في

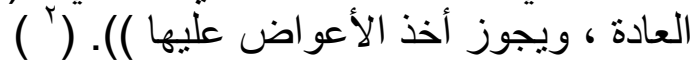

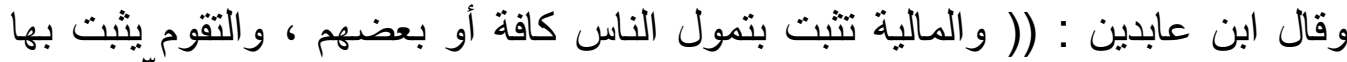

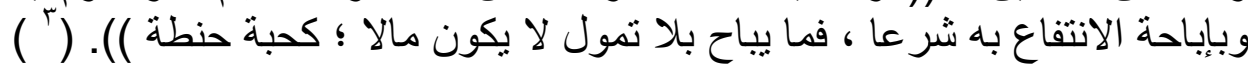

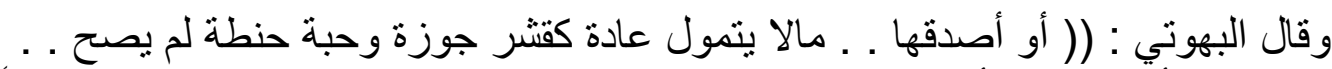

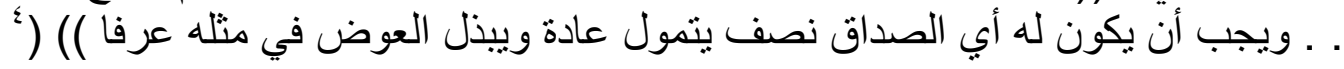

وفي النكت والفو ائد السنية (º) . - في من أقر بشيء- : " لو فسره بحبة حنطة ونحوها لم يقبل ؛ لعدم تمول ذلك على انفر اده عادة " . .

و هنا نلاحظ في نصوصهم أنهم يحكمون العرف في ذلك ؛ أي أن التمول يثبت بالعرف .

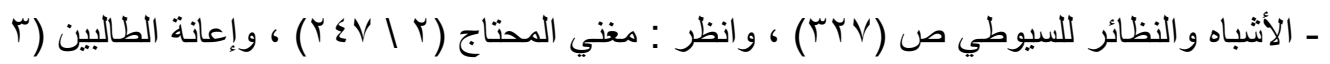

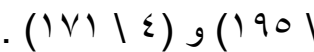

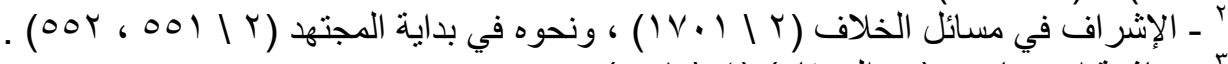

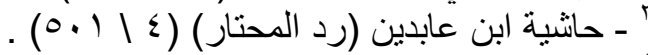

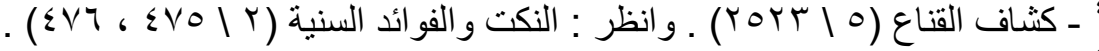

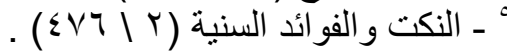


و هو أيضا ما نبه إليه الفيومي حيث قال : (( فقول الفقهاء : (ما يتمول) أي ما يعد مالا

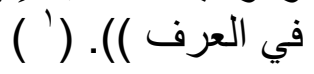

ومما يدخل في المتمول ما يتمول في المآل أي في ثاني الحال ، وإن لم يكن متمولا في

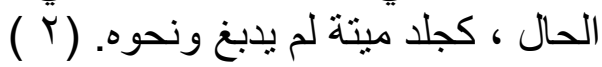

ولكن : هل من شرط المالية التمول أي هل يسمى الثيء مالا وإن كان قليلا غير متمول؟

\section{ينمر الصنهية على أز التمول شرط في المالية :}

قال السرخسي : " المالية لا تسبق الوجود وبعد الوجود تثبت بالإحراز والتمول " ( ) ) ،

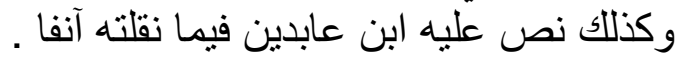

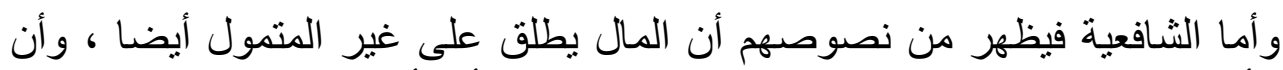

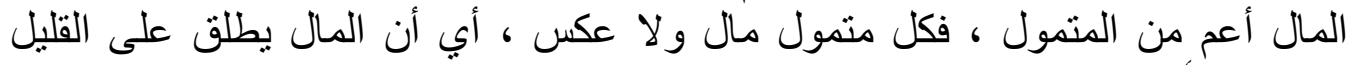

$$
\text { و الكثير. ( }
$$

لكن المال المتمول يختص عن المال غير المتمول بأحكام عندهم رأيت منها : 1 - أن المتمول يصح جعله عوضا بخلاف غير المتمول. ( )

r - أن الغبن بغير المتمول لا يثبت فيه الخيار قطعا ، واختلف في المتمول القليل. ( ) ب ـ أن الخلاف في حل لقطة الحرم -بعد التعريفــ إنما هو في المتمول ، أما غير

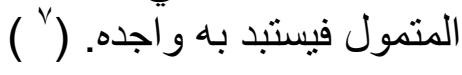

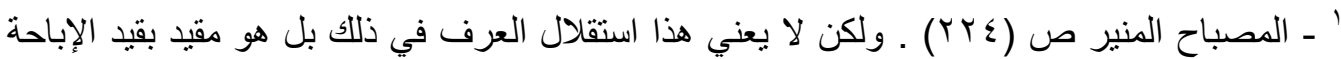

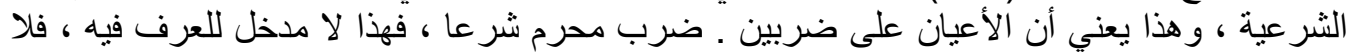

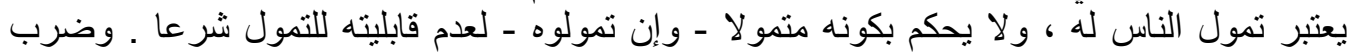

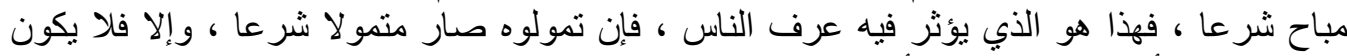

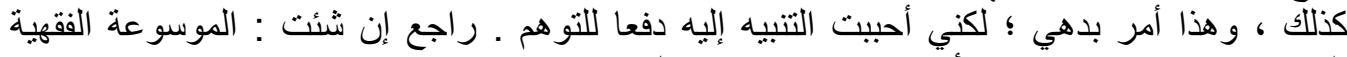

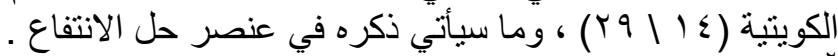

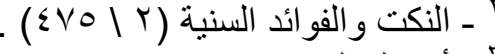

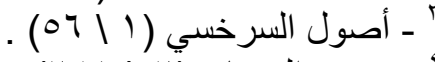

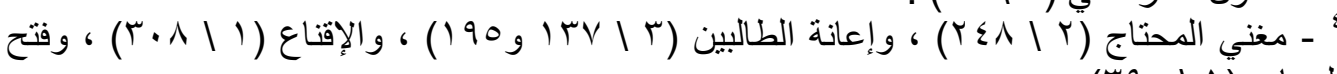

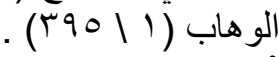

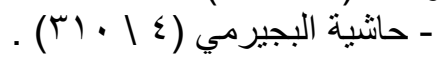

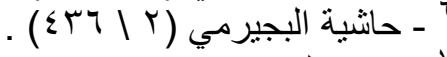


ع - أن الصائل إنما يدفع بالضرب عن المال المتمول دون غيره في احتمال عندهم. ( ) )

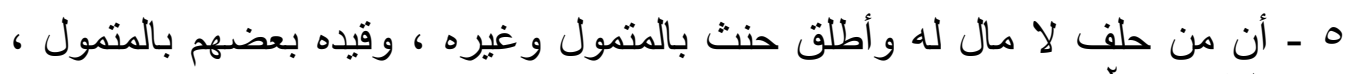

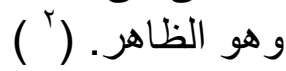

7 - أن من غصب مال غيره المتمول ؛ فعليه الإثم والضمان ، ومن غصب مال غيره

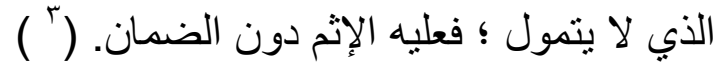

\section{المطلب الثالث}

\section{التطبيقات على القاعدة}

ذكر الفقهاء تطبيقات كثيرة على هذه القاعدة،من هذه المسائل على سبيل المثال :

ا- بيع الحقوق المعنوية : يصح بيع الحقوق المعنوية كالتأليف ، والدليل على ذلك :

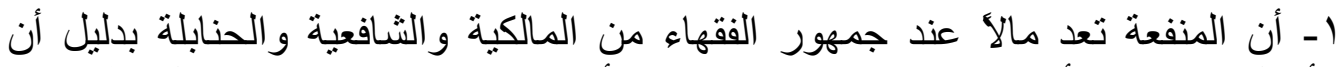

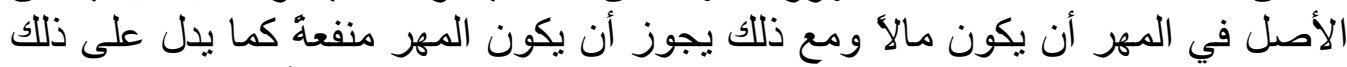

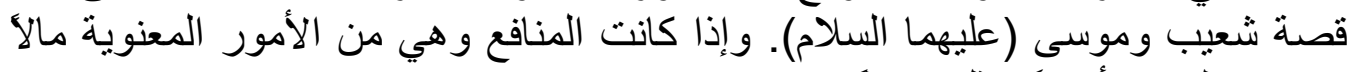
فالإنتاج الذهني أيضأ يمثل منفعة من منافع الإنسان.

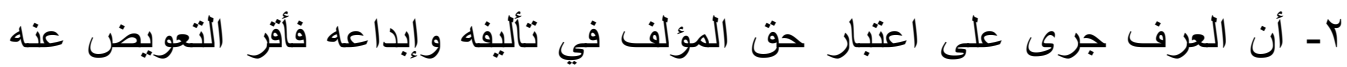

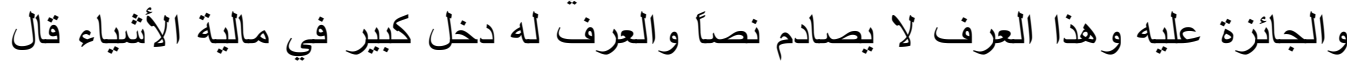

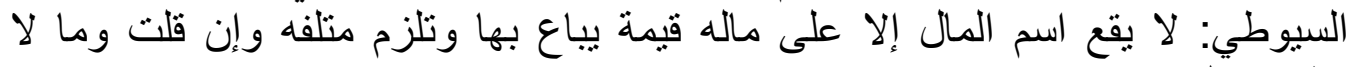

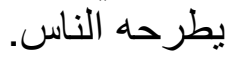

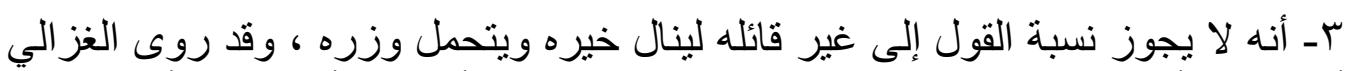

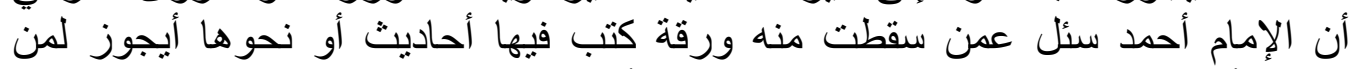
وجدها أن يكتب منها ثم يردها ؟ قال: لا بل بيتأذن.

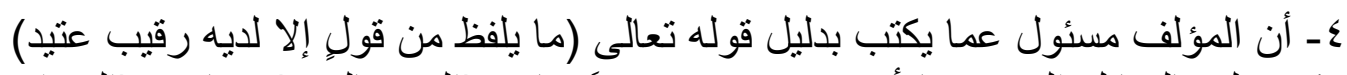
فيككون له بالدقابل الحق فيما أبدعه من خير عملا بقاعد (الغنم بالغرم) وقاعدة (الخراج

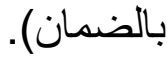

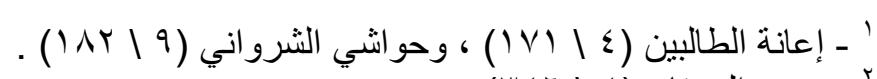
(

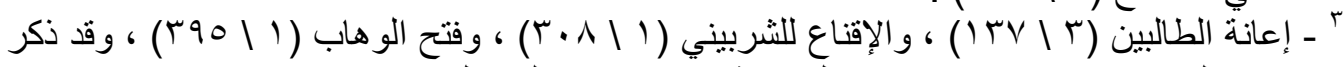

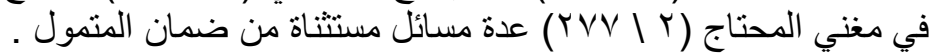


هـ الإبداع الذهني أصل للوسائل المادية من سيارة وطيارة ونحوها فلا بد من اعتبار

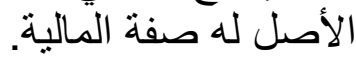

$$
\text { - ومن الحقوق المعنوية التي يجوز بيعها أيضا حق ( براءة الاختراع ). }
$$

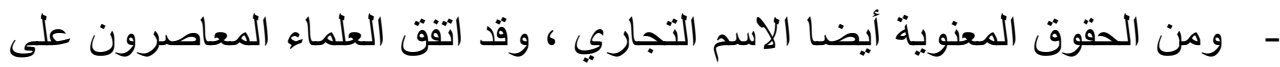

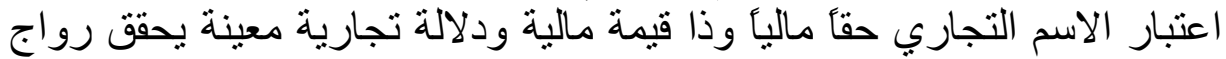

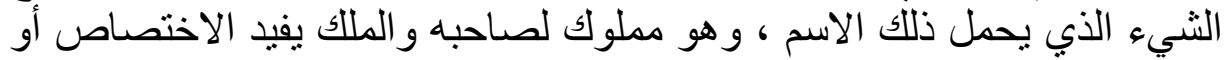

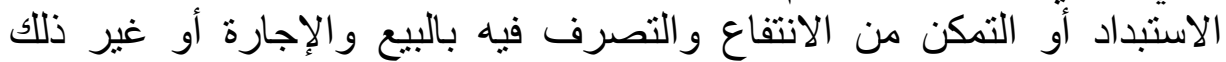

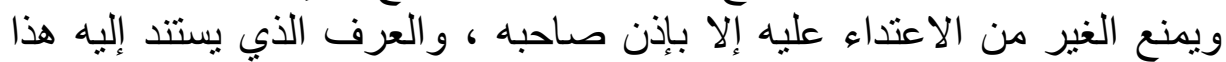

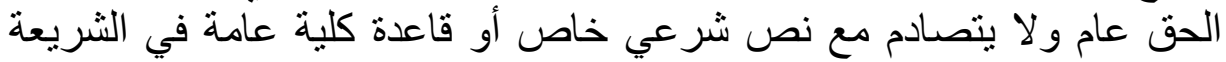

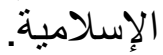

\section{رأي مجمع الفقهه الإسبلامي في هقور الابتتكار:}

لقد طرح مجمع الفقه الإسلامي موضوع الحقوق المعنوية أو حقوق الابتكار في دورته

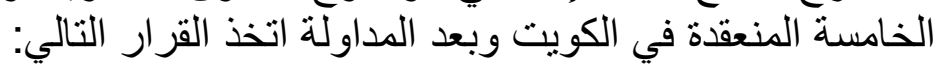

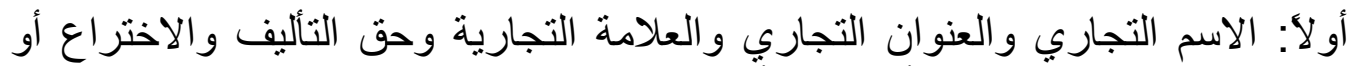

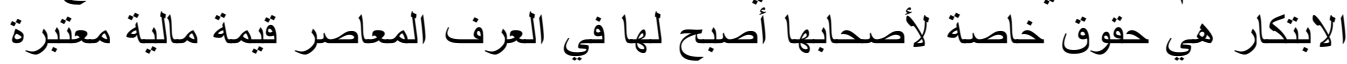
لتمول الناس بها وهذه الحقوق يعتد بها شرعا فلا يجوز الاعت الاعتداء عليها ـ ثانياً: يجوز

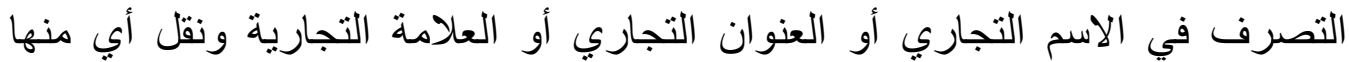
بعوض مالي إذا انتفى الغرر والتدليس والغش باعنبار أن ذللك أصبح حقا ماليا.

و أفتت اللجنة الدائمة للبحوث العلمية بما يلي: لا مانع من تسجيل الأشرطة النافعة وبيعها الإنها

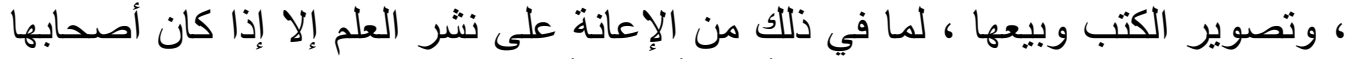

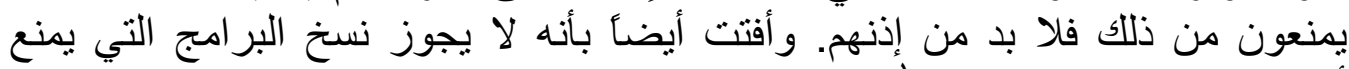

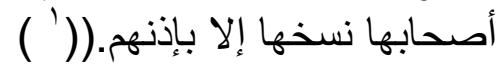

r- بيع ما يكره ويحرم لبسه للرجال والنساء : يجوز بيع ما يحرم لبسه للرجال

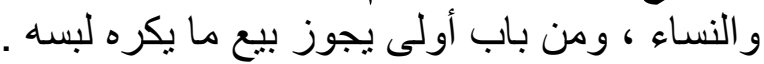

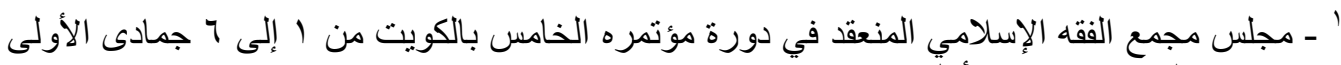

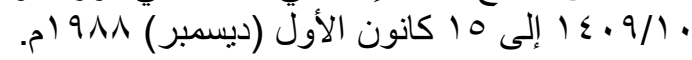




\section{ويمكن الاستدلال على ذلك بحديثين رواهما البخاري ومسلم :}

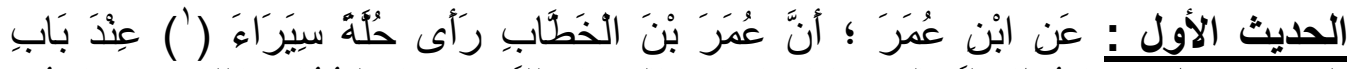

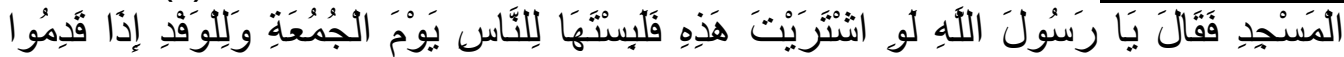

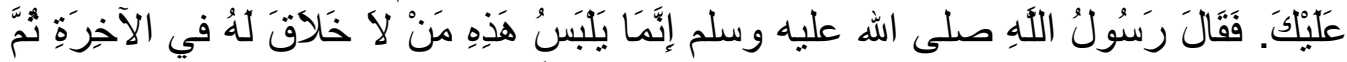

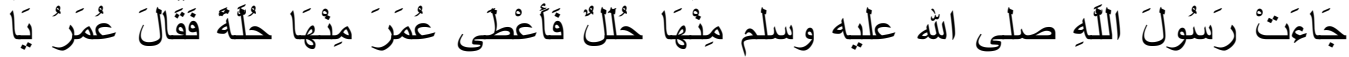

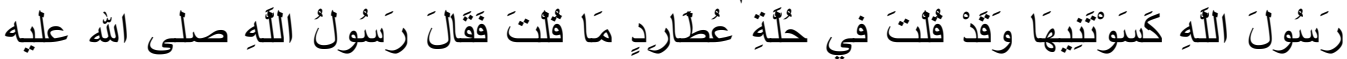

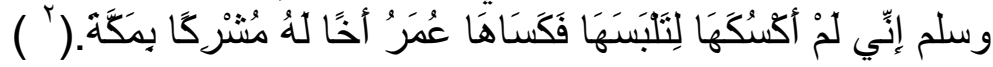

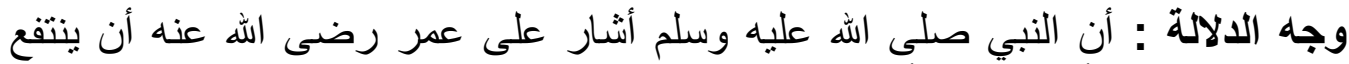

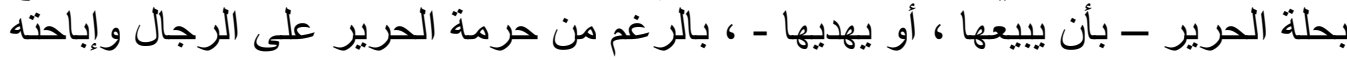

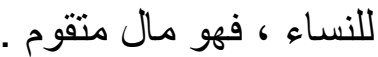

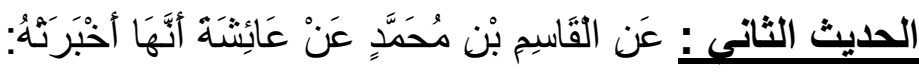

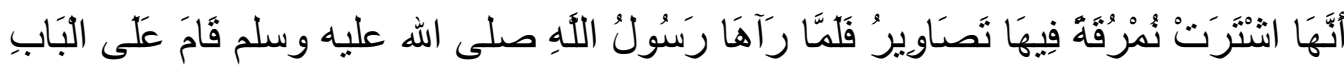

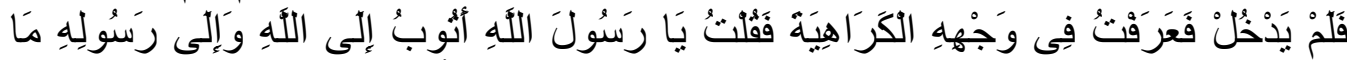

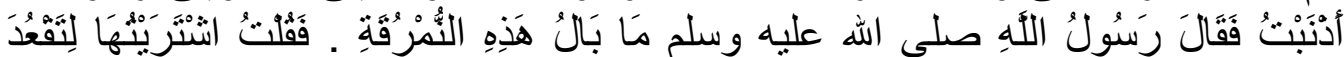

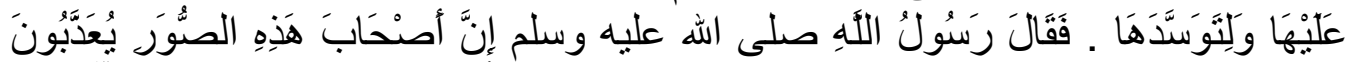

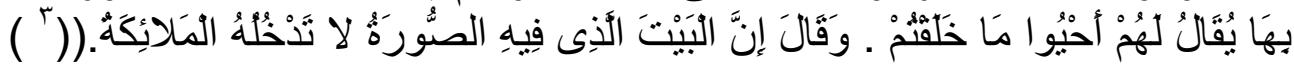
وجه الدلالة : أن النبي صلى الله عليه وسلم لم يفسخ العقد في النمرقة ، بالرغم من فن

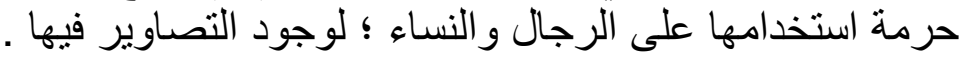

\section{ويستناد من هذه الأحاديثذ :}

أن ما له اكثر من استخدام ، أو له وجهان في الاستعمال جاز بيعه ، فالمحرم بالنسبة

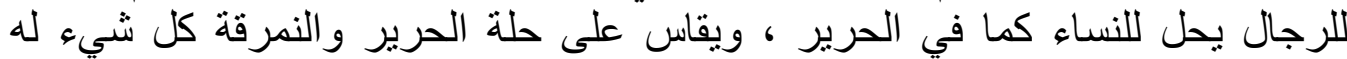

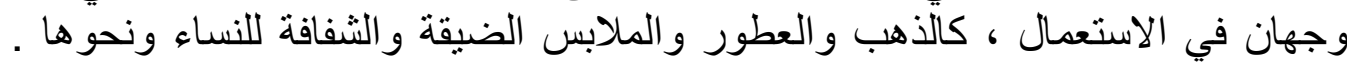

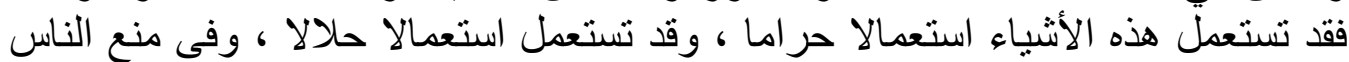

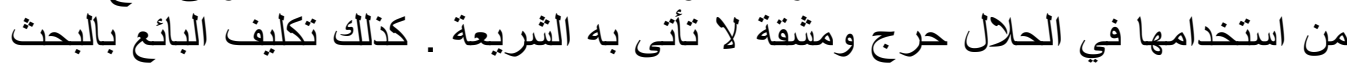

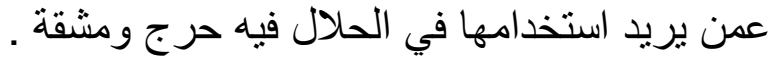

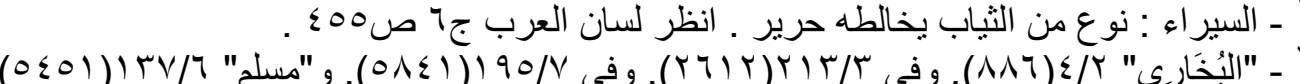

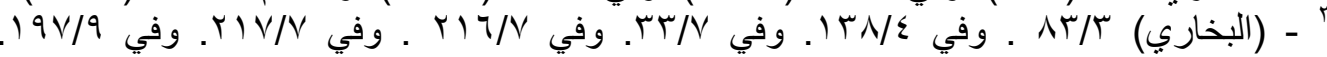


ب - بيع اللاعب الرياضي ؛ يجوز بيع منفعة اللاعب الرياضي ؛ لأنه هذه المنفعة

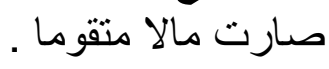
ع - بيع أرقام الهواتف والسيارات : تمثل أرقام الهواتف والسيار ات منفعة معنوية

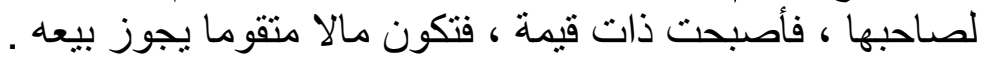
ه - الملابس الضيقة والشفافة : هذه الملابس لها استخدام ومقصود حلال ، كالتزين

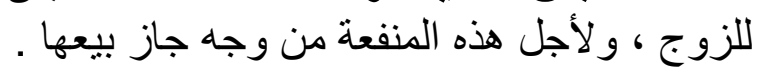




\section{المبمث الثناني}

\section{القاعدة الثانية ( قاعدة اليسير مفتفر )}

\section{المطلب الأول}

\section{صبيز القا عدة وبيان معنـاها}

نص العلماء على القاعدة بعبارات مختلفة ، من ذلك ما يلي:

قال الجصاص : "العمل اليسير معفو عنه".(')

وقال ابن قدامة : "اليسير تجري المسامحة فيه".(")

وقال ابن مفلح : "الثيء اليسير الذي لا ينضبط، لا يلتفت إليه".(")

وقال الونشريسي والندوي : "اليسير معفو عنه في كثير من الأحكام".(")

وقال الدبوسي : "اليسير معفو عنه".( )

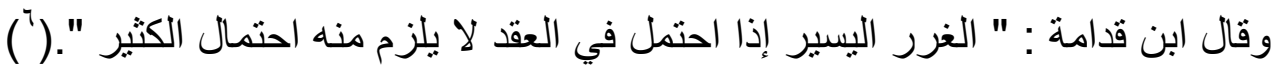

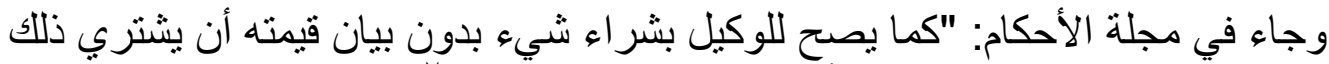

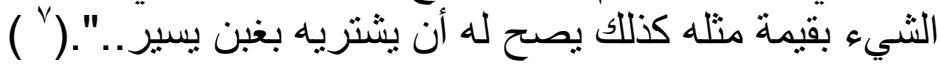
وجاء في القواعد النورانية : " الضرر اليسير يحتمل في العقود ".( )

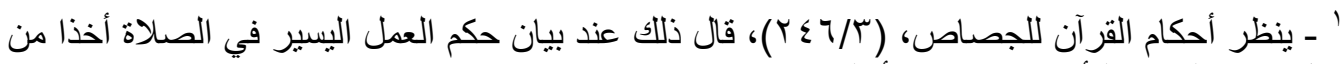

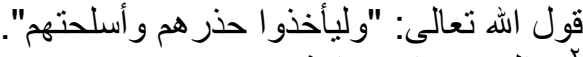

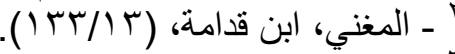

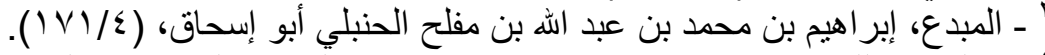

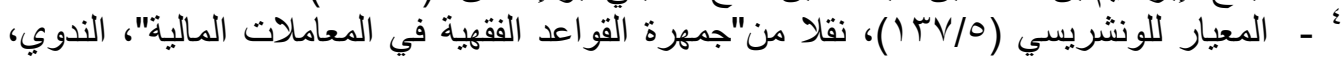

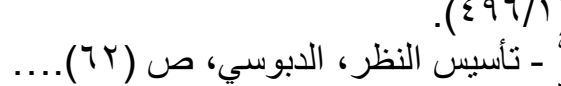

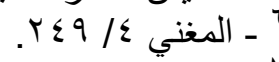

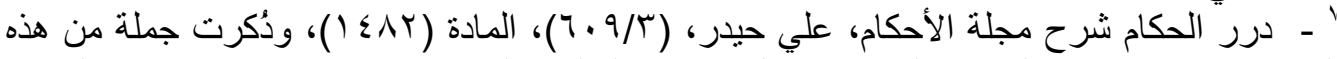

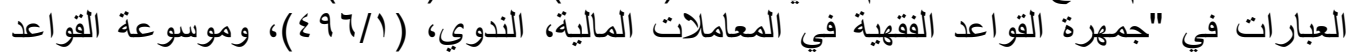

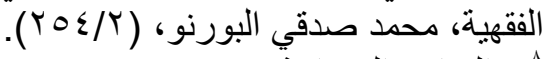


المراد بالضرر اليسير: الذي لا يُخلٌّ بمقصود العقد، ويتسـاهل فيه الناس. مهاد القاعدة: أن وجود مثل هذا الضرر لا يفسد العقد، بل بصح العقد مع وجوده

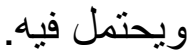

\section{المطلب الناني}

\section{بم بعرف كوز الشيء بيسير1 ؟}

الأصل عند أنمة الحنفية الثلاثة: أن القليل من الأشياء معفو عنه ، و عند زفر لا يكون

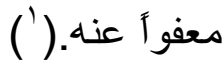

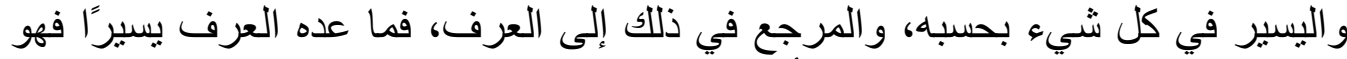

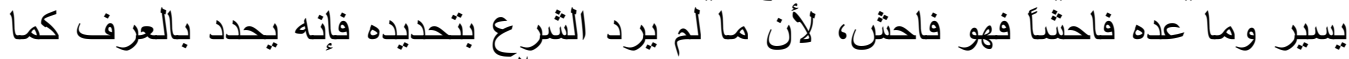

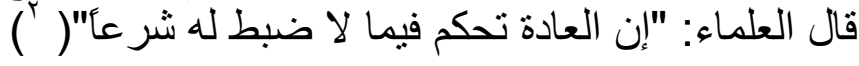

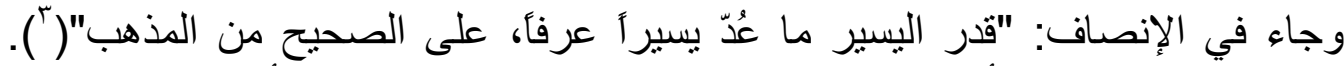

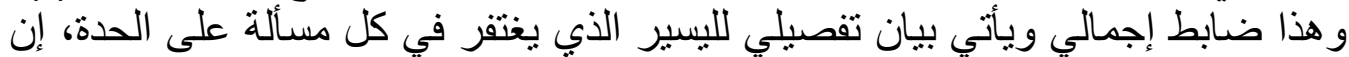

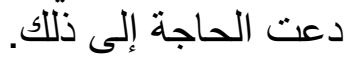

ولتمام فهم القاعدة ومعرفة اليسير الأي يغتفر لا بل من إثارة إلى مواضع إعمال

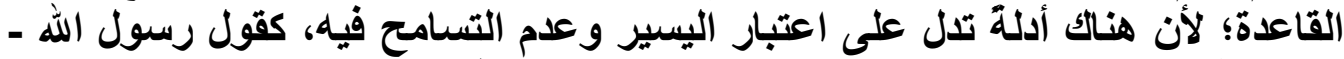

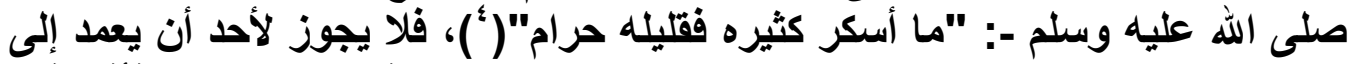

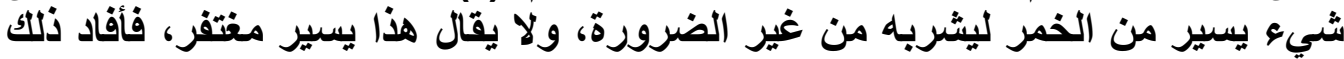

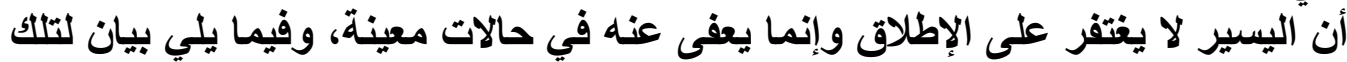

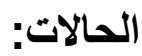

$$
\begin{aligned}
& \text { ' - تأسيس النظر صـ Y T وصد } 90 \text { ط طديدة. }
\end{aligned}
$$

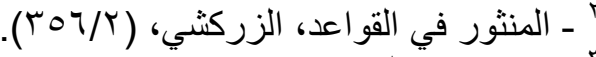

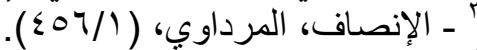

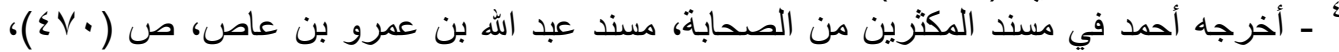

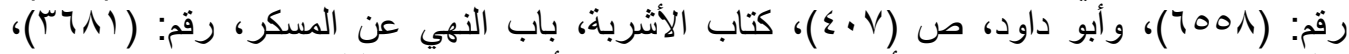

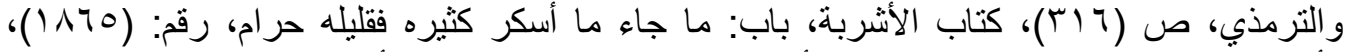

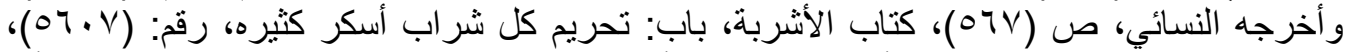

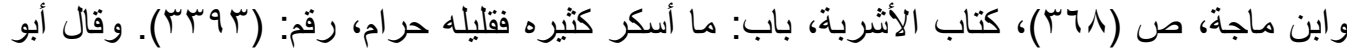

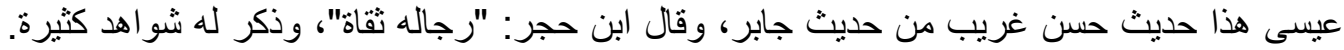

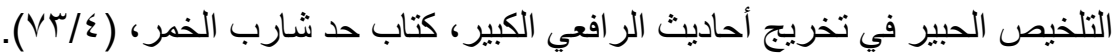


أولا: اليسير الذي يثق التحرز منه، كالعفو عن يسير النجاسة بعد الاستجمار لقول

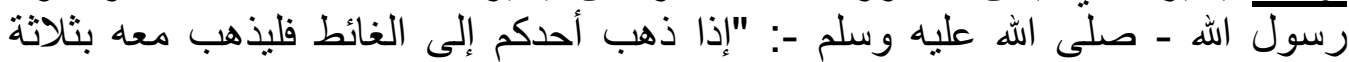

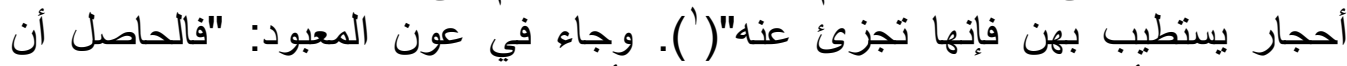

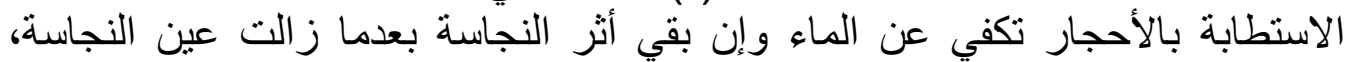

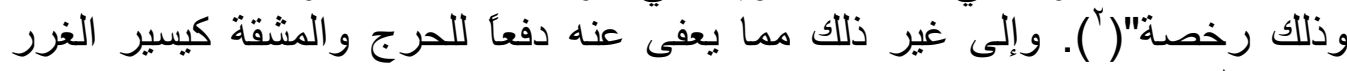

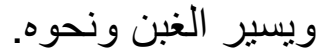

ثانيا: ما لا أثز له لكونه مستهلكأ في غيره؛ كإنفحة( آ) الميتة التي بصنع بها الجبن، وقد

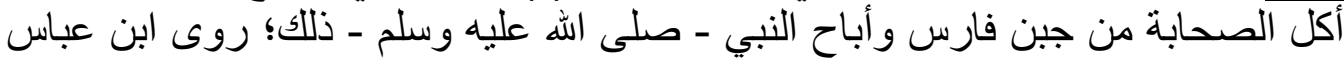

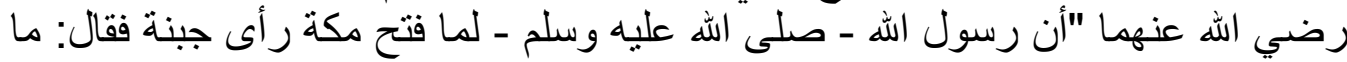

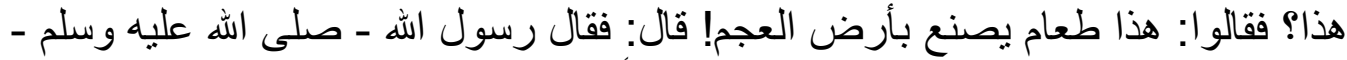

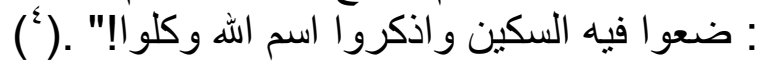

ولا ينعقد الجبن إلا بإنفحة، ومعلوم أن ذبائح المجوس ميتة وقد أباح عليه النبي - صلى ألى إنه الله عليه وسلم - أكله مع العلم أنه من صنع أهل ألهل فارس وكانوا إذ ذالك مجوسأ.

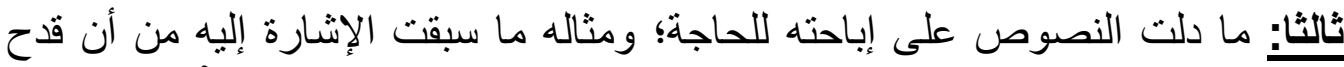

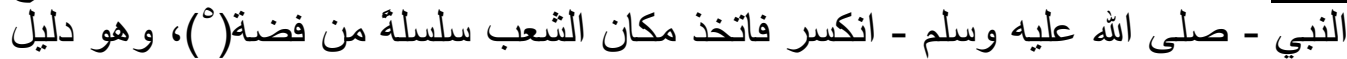

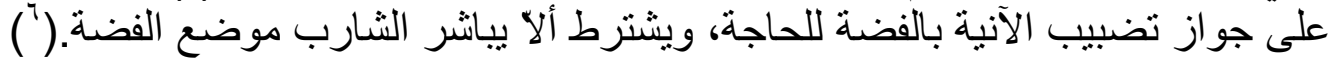

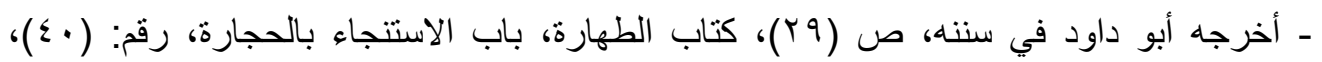

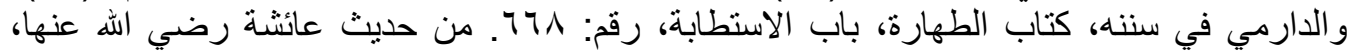

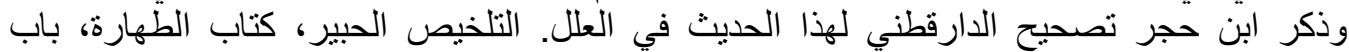

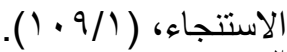

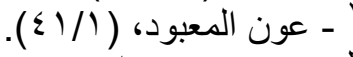

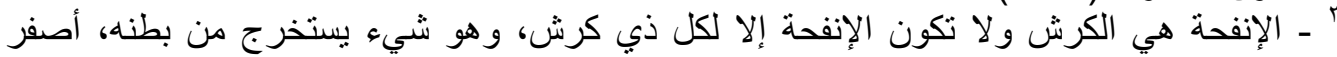

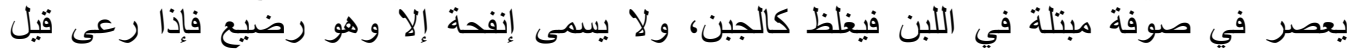

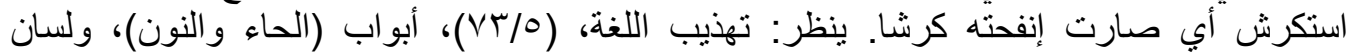

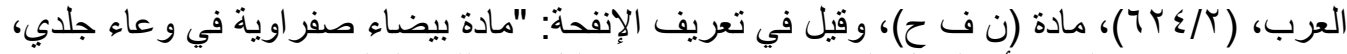

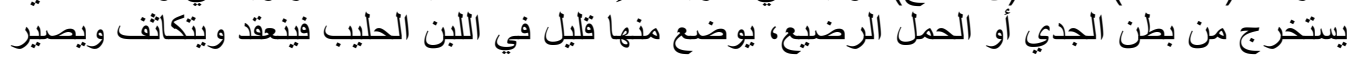

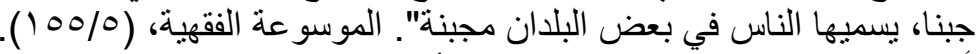

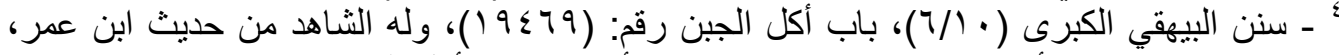

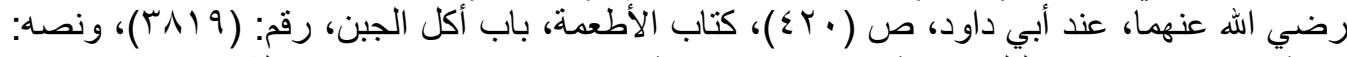

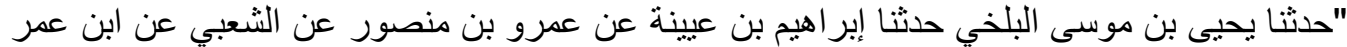

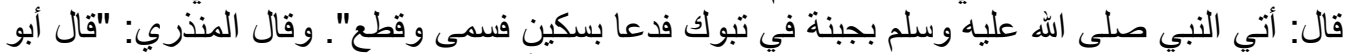

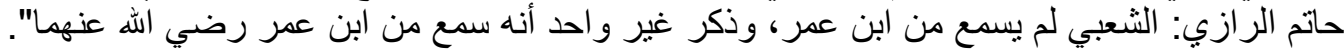

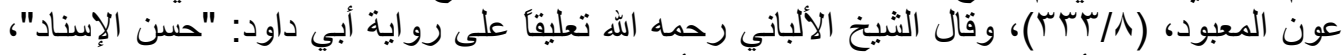

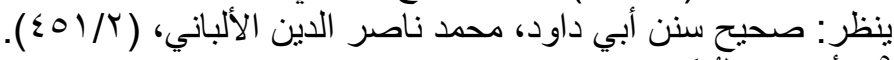

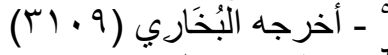
- ينظر : فتح الباري، ابن حجر العسقلاني، ( • /عـ • (). 


\section{المهالب الثالث}

\section{أدلة قاعدة اليسير مغتنفر}

\section{من الأدلة التي استدل بها العلماء على هذه القاعدة ما يلي:}

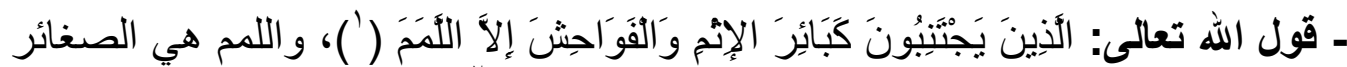

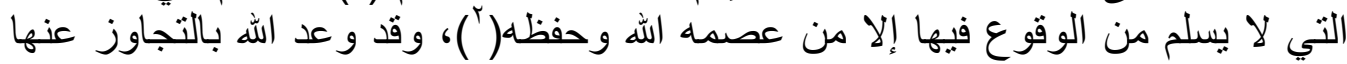

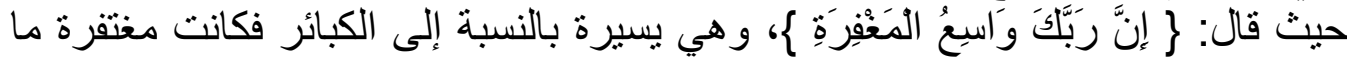

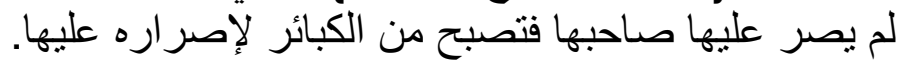

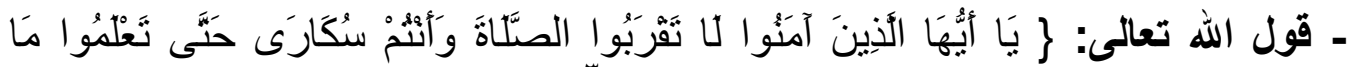

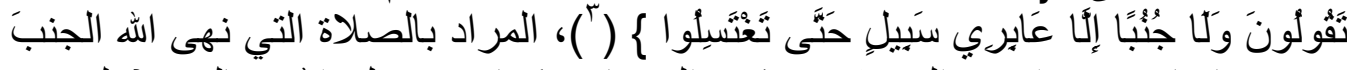

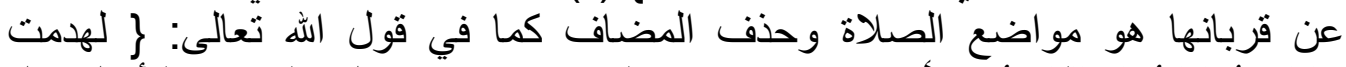

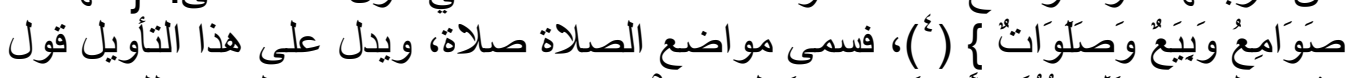

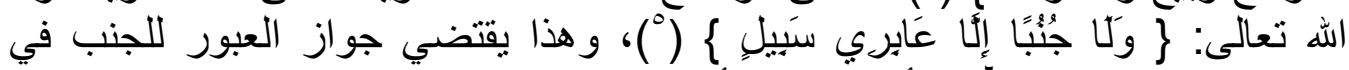

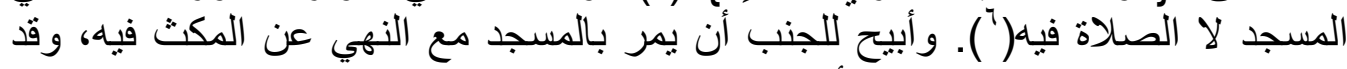
يفيد هذا اغتفار شيء بسير، والهاء واله أعلم.

- و وعن أنس بن ماللك - رضي الله عنهم - "أن قدح النبي - صلى الله عليه وسلم - انكسر

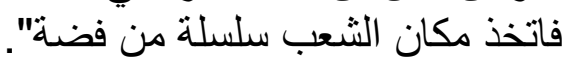

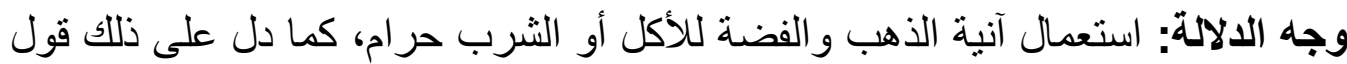

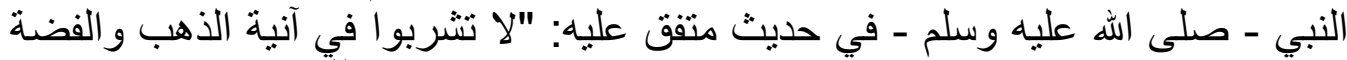

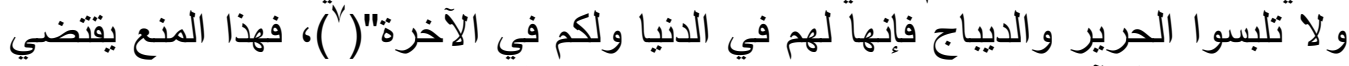

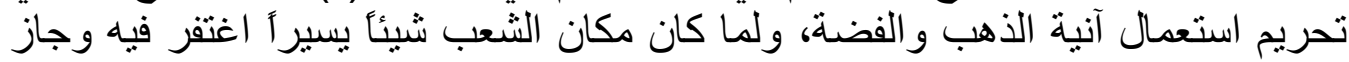

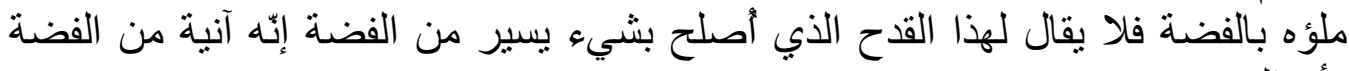

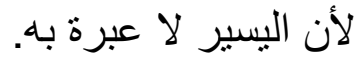

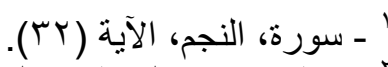

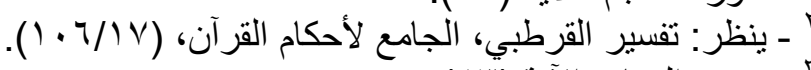

$$
\begin{aligned}
& \text { ك - سورة النساء، الآية (تَع). } \\
& \text { - سورة الحج، الآية (•ـ؛). }
\end{aligned}
$$

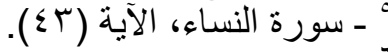

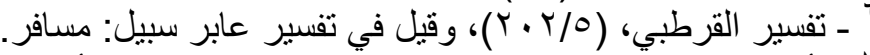

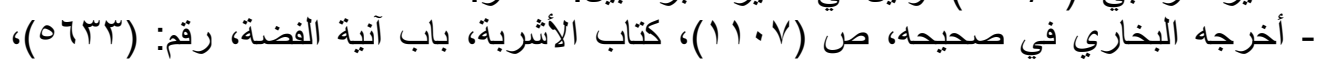

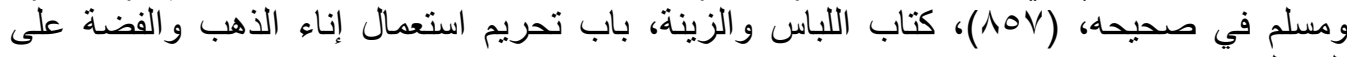


- وخطب عمر بن الخطاب - رضي الله عنه - بالجابية فقال: "نهى نبي الله - صلى الله إله

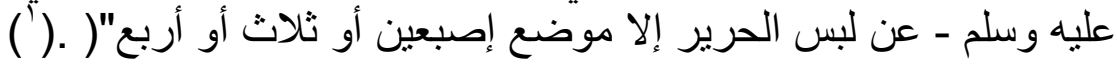

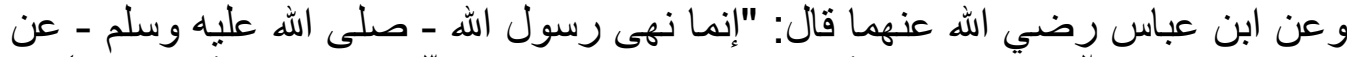

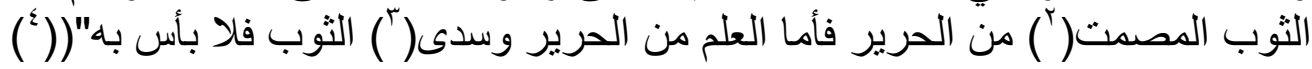

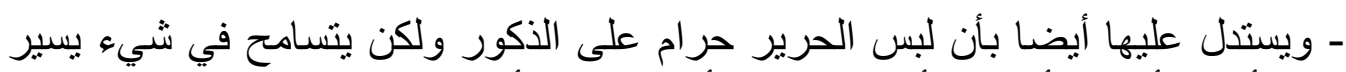

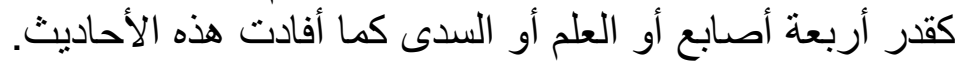

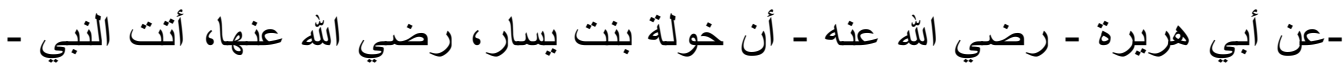
صلى الله عليه وسلم - فقالت: "يا رسول الله إنه ليس لي إلا ثوب وان واحد و وأنا أحيض فئ فيه

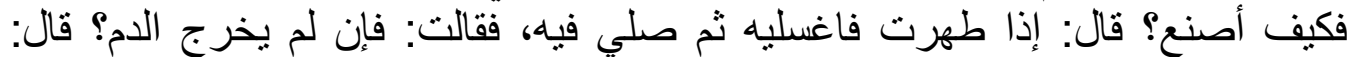

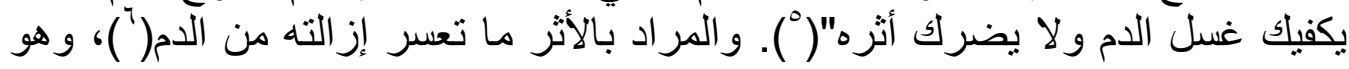

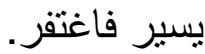

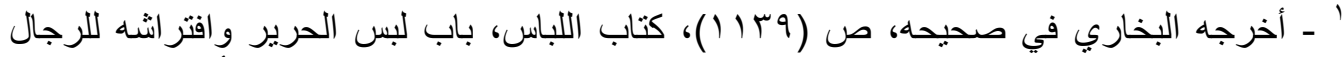

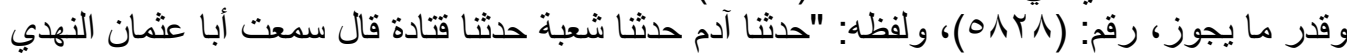

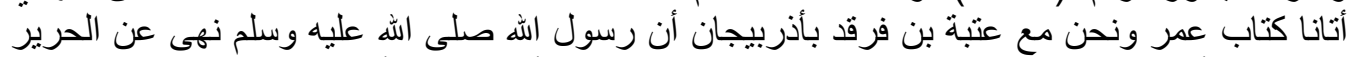

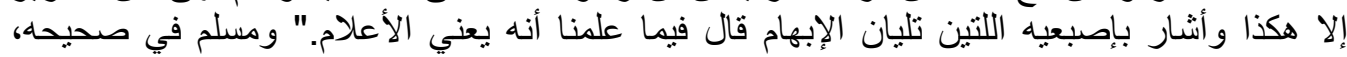

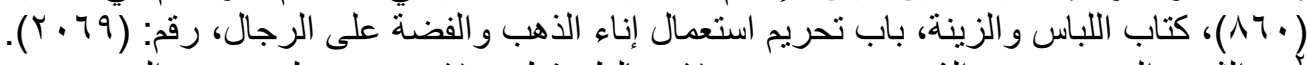

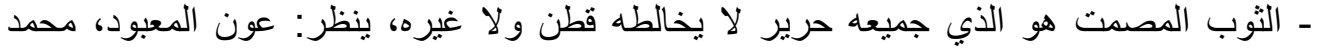

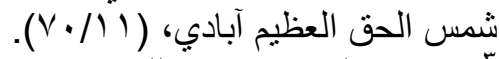
' آ - سدى الثوب خلاف اللحمة وهي التي تنسج من العرض وذاك من الطول، ينظر المرجع السابق: . $(\mathrm{V} \cdot / 1)$

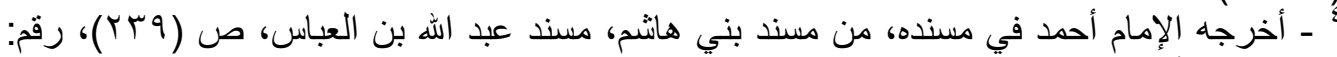

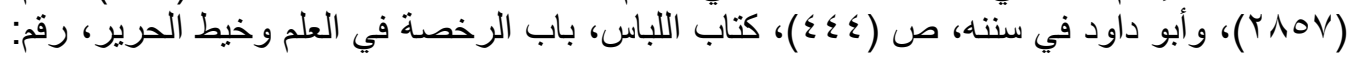

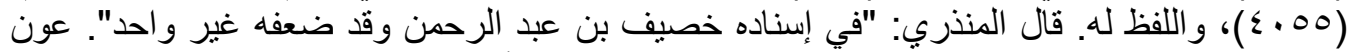

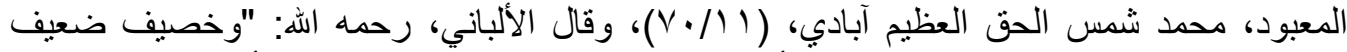

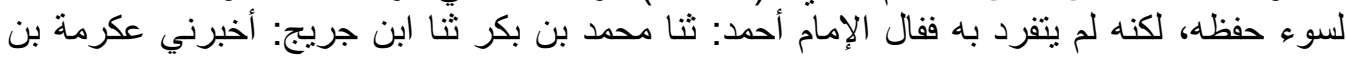

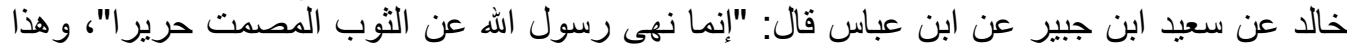
سند صحيح على شرط الثيخين". إرواء الغليل في تخريج أحاديث منار السبيل، محمد ناصر الدين الدين

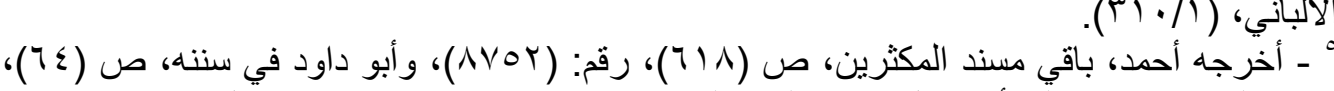

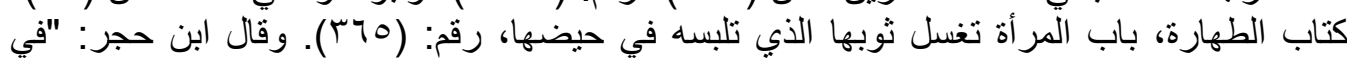

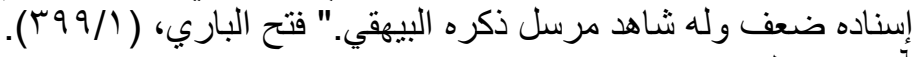




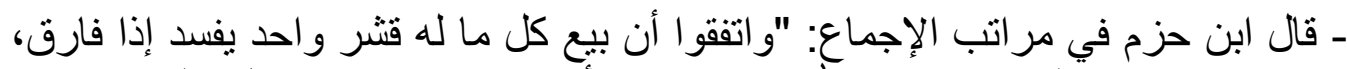

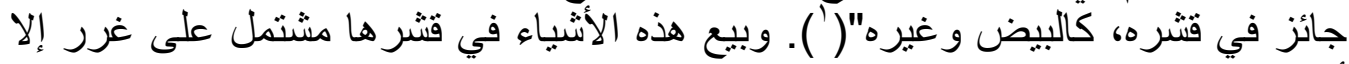
أن هذا آلغرر يسير فاغتفر.

\section{المطll}

\section{تطبيقات الفقهاء على القاعدة}

\section{ا -حكم الغذاء والاواء المشتمل على محرم يسير:}

اختلف العلماء في المحرم الأي يغتفر إذا خالط المباح، ومن ذلألك اختلافهم في الماء إذا

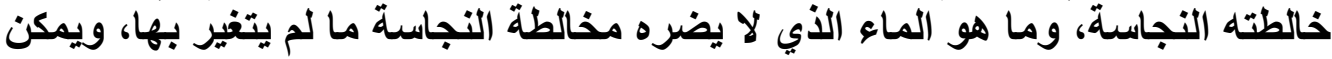
إجمال آرائهم في قولين:

القول الأول: التفريق بين الماء القليل و الكثير، فإن كان الماء قليلا وخالطته النجاسة فهو

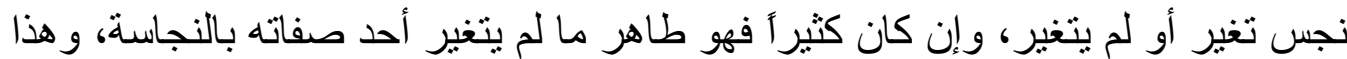

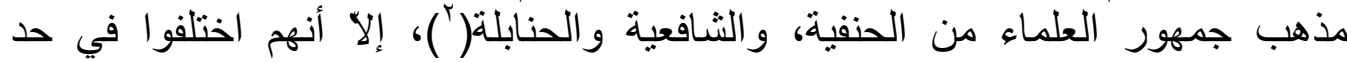

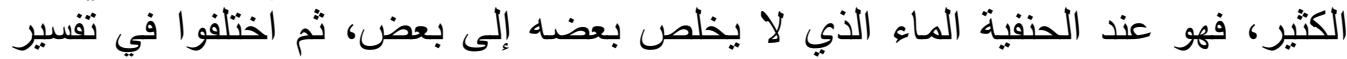

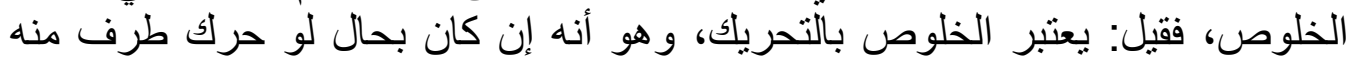

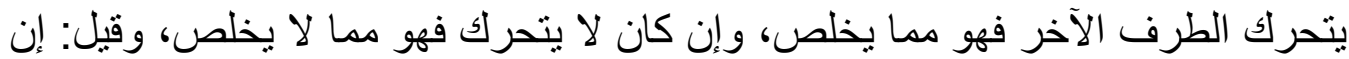

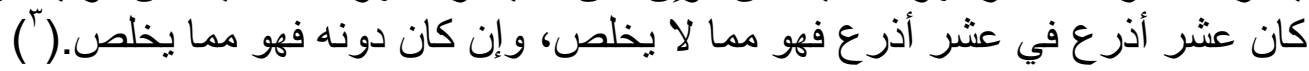
وحد الكثير عند الثنافعية، والحنابلة( ) ما بلغ القلتين.

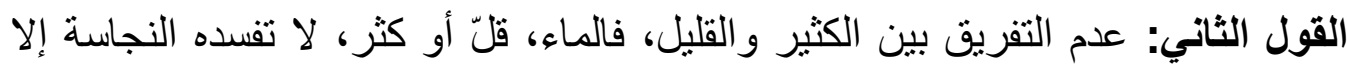

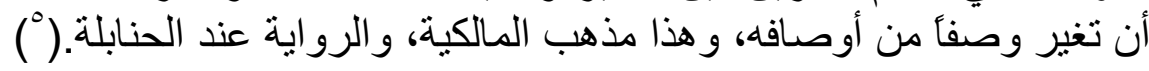

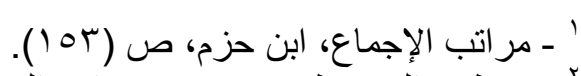

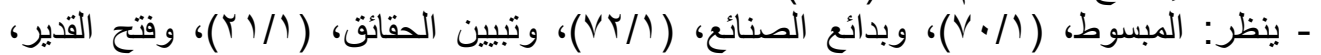

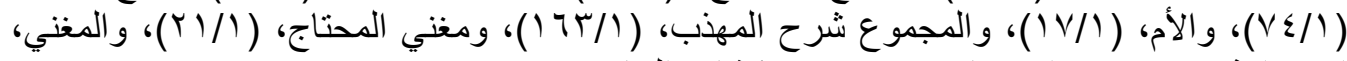

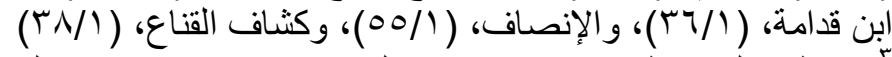

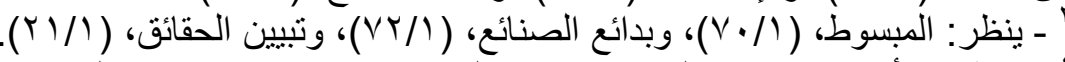

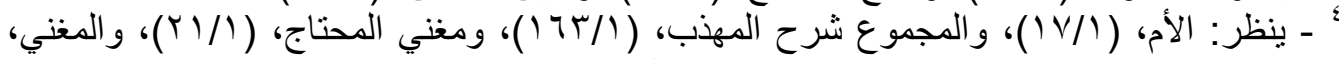

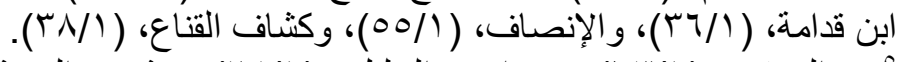

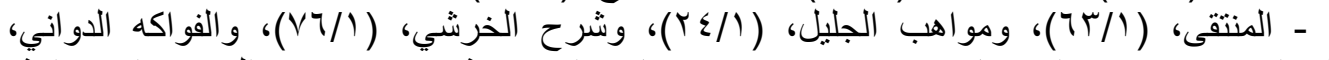

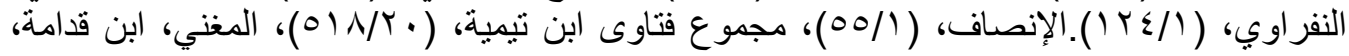


بعد عرض أقوال العلماء وأدلتهم في مسألة محرم يسير إذا خالط المباح واستهلاك فيه

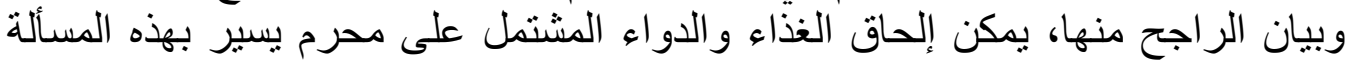

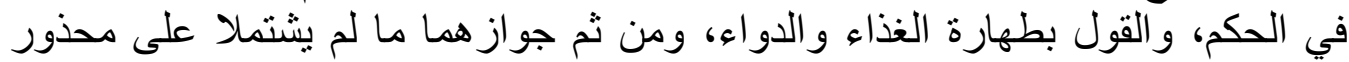

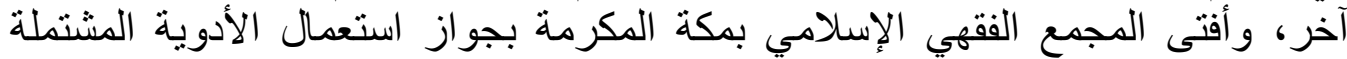

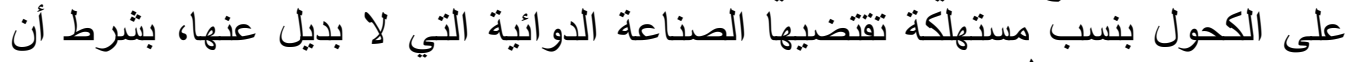
يصفها طبيب عدل('). وتوصل الكثير من الباحثين إلى الحكم بطهارة المواد الئه الغذائية

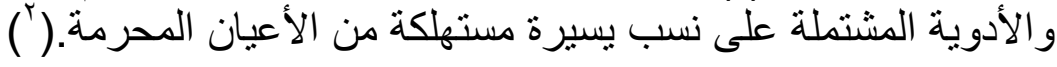

\section{وجه تنفريج المسألة على القاعدة :}

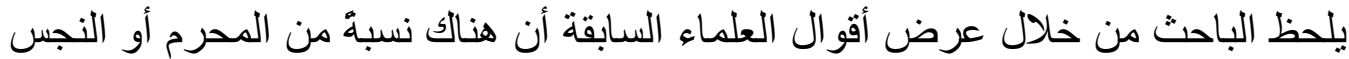

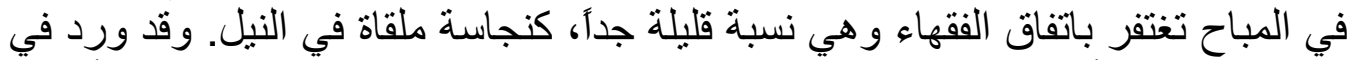

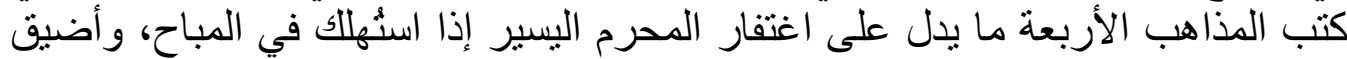

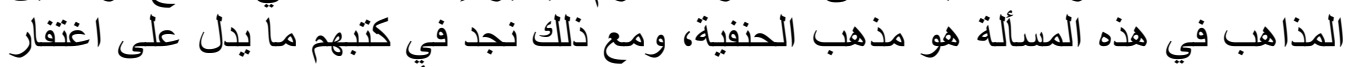

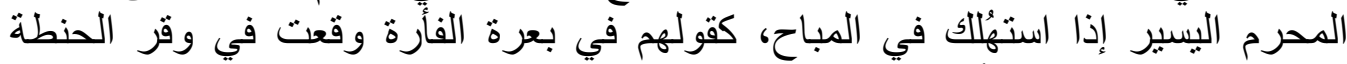

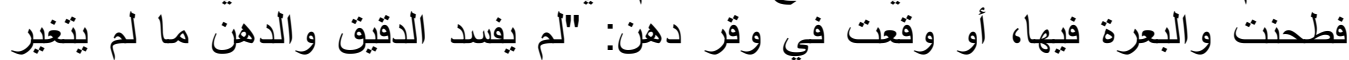

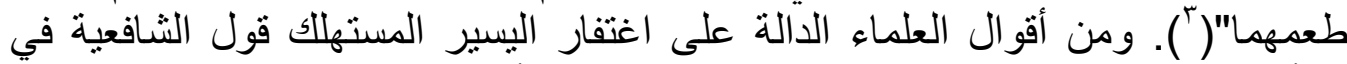

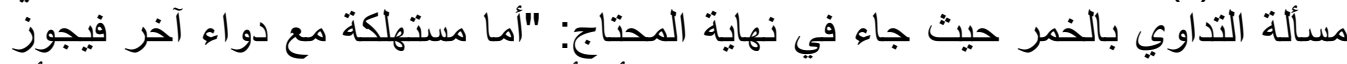

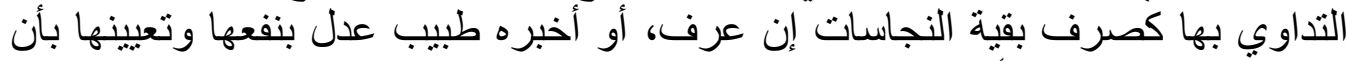

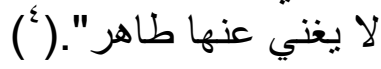

r - الأسهم المشتملة على محرم يسير.

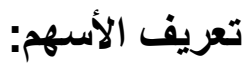

السهر هو: "صك قابل للتداول يصدر عن شركة مساهمة، ويعطى للمساهم ليمثل حصته

في رأس مال الشركة". ( )

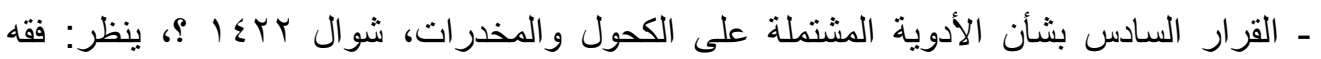

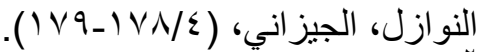

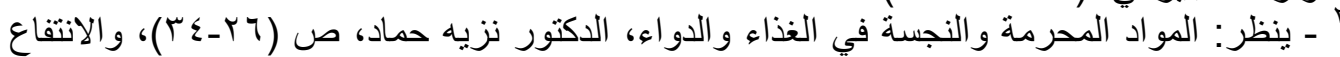

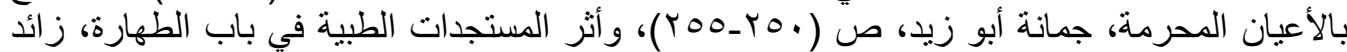

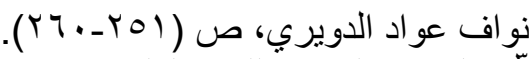

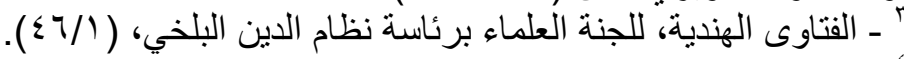

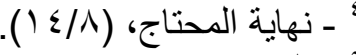

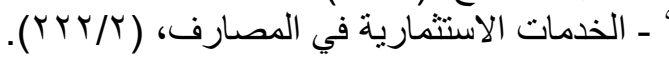


تتنوع الأسهم باعتبار ات مختلفة إلى أنواع كثيرة وكل نوع لله حكم يخصده، و الذي يعنينا

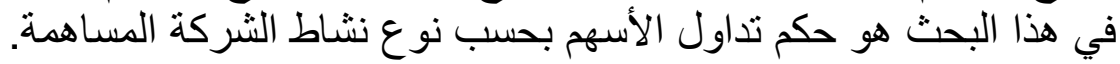

\section{ويمكن تقسيم الشركات المساهمة بهذا الا عتبار إلى ثلاثة أنواع:(')}

النوع الأول: الثركات المحرمة، وهي الثركات التي يكون نشاطها الرئيس في أمور

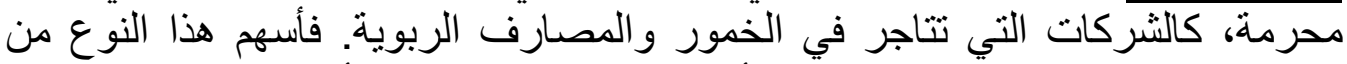

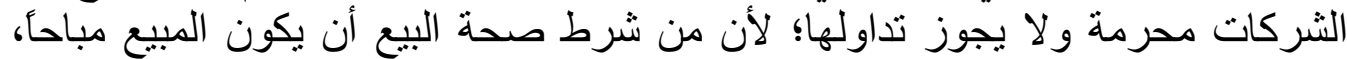
و هذه الأسهم محرمة، وشر واؤها من باب المشاركة في الإثم و العدوان.

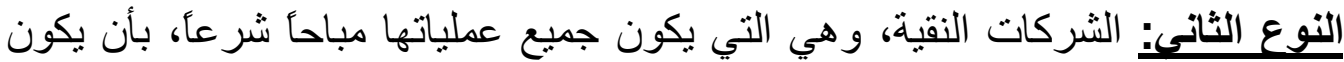

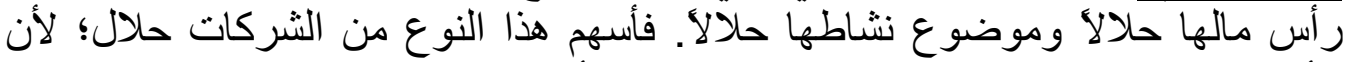

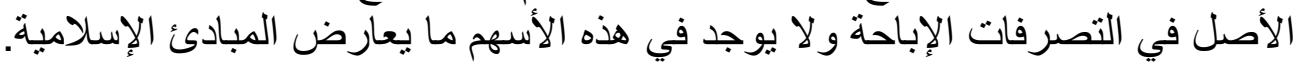

النوع الثالث: الثركات المختلطة، وهي التي يكون أصل نشاطها حلالا ولكنها أحيانا

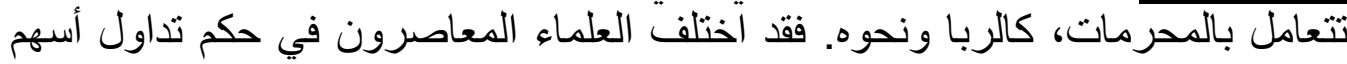
هذا النوع من الثركات إلى قولين:

القول الأول: جواز المساهمة في هذه الثركات، بشرط ألا ينص نظامها الأساسي على الثى

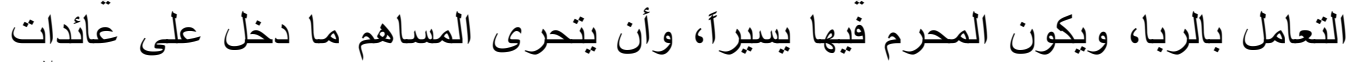

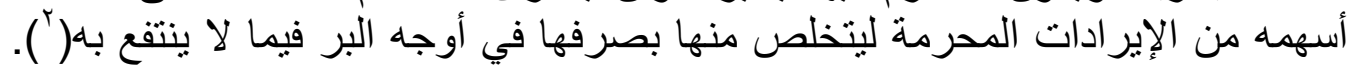
و اشترط بعض أصحاب هذا القول كون الثركة من الثركات الثرات الحيوية التي تؤدي خدمات التهات

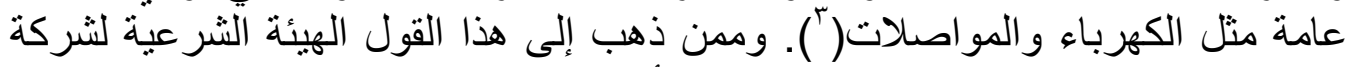

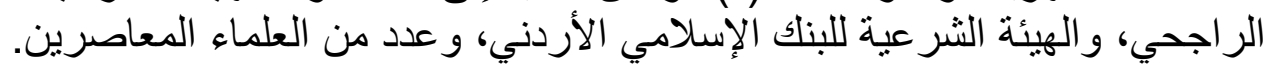

القول الثاني: تحريم المساهمة في هذه الثركات مطلقاً، وذهب إلى هذا القول اللجنة

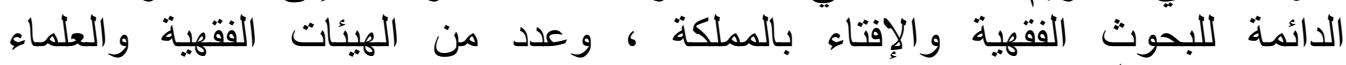

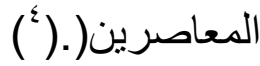

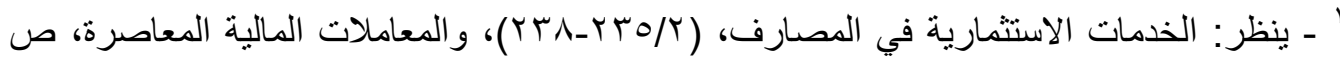

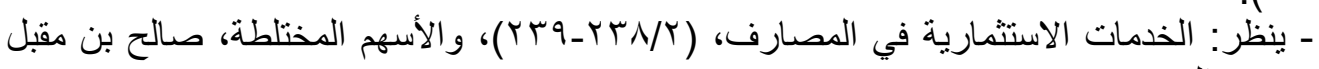

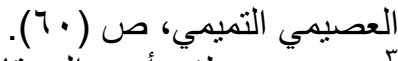

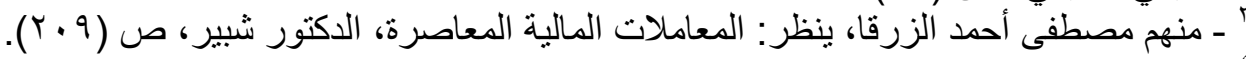

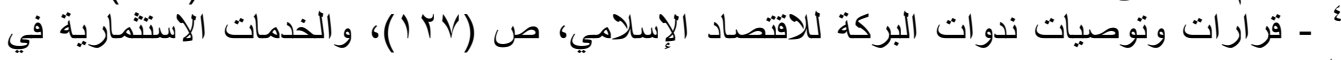




\section{وجه تنفربيج المسألة على القا عدة:}

تدخل هذه المسألة في تطبيقات القاعدة على قول من أجاز تداول أسهم الثركات التي

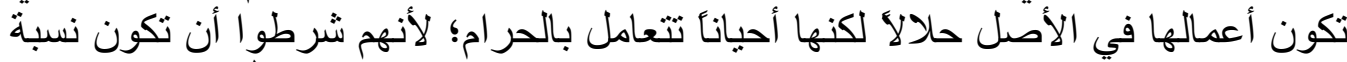

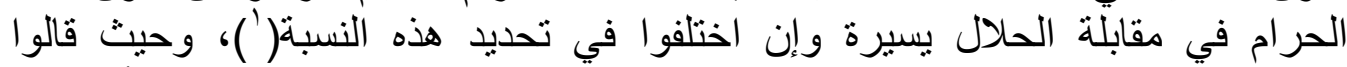

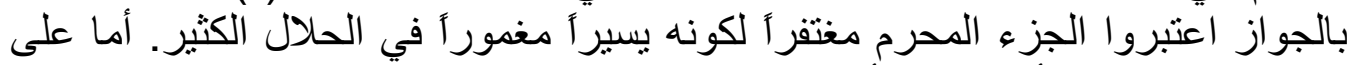

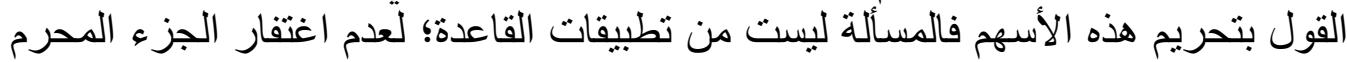
منها و إن كان بسيراً.

\section{r - عقود التأمين التجاري المشتملة على غرر يسير.}

التجاري أو التأمين بقسط ثابت، وهو النوع السائد الآن الذي تتصرف إليه كلمة التأمين

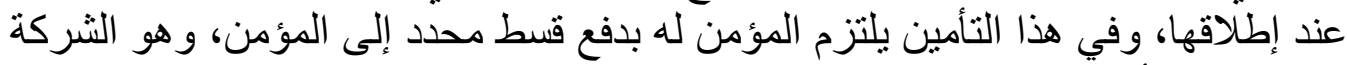

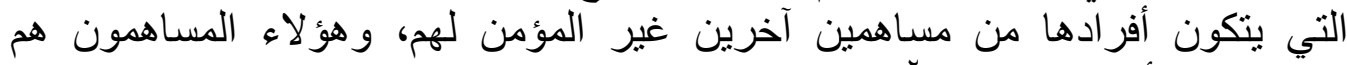

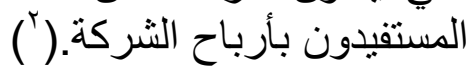

حكمه: اختلف الفقهاء المعاصرون في حكم هذا التأمين على قولين:

القول الأول: تحريم التأمين التجاري، وهو قول جمهور الفقهاء المعاصرين، وبه صدر قرار هيئة كبار العلماء في المملكة العربية السعودية ومجمع الفقه الإسلامي بمكة الفئ المكرمة.

القول الثانى: جواز التأمين التجاري، وهذا قول بعض المعاصرين وانتصر لله الثيخ

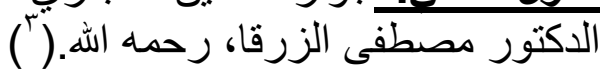

\section{وجه تنفربه المسألة على القاعدة :}

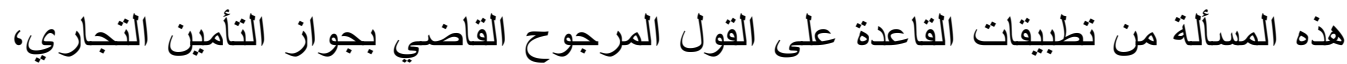

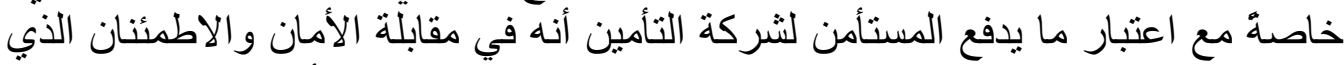

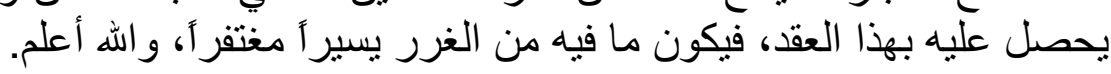

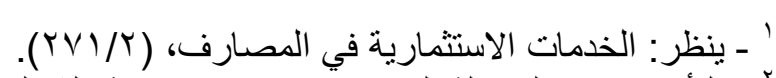

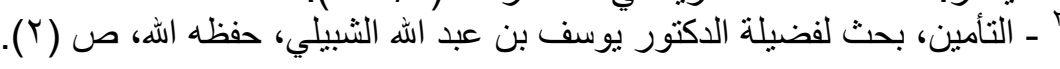

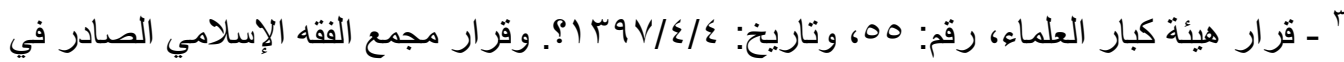

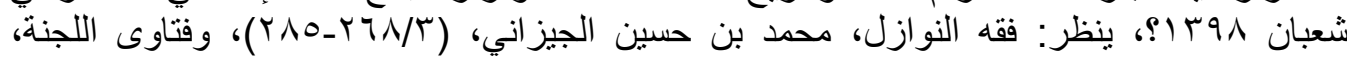


أما على القول القاضي بتحريم التأمين التجاري فليست هذه المسألة من تطبيقات القاعدة؛

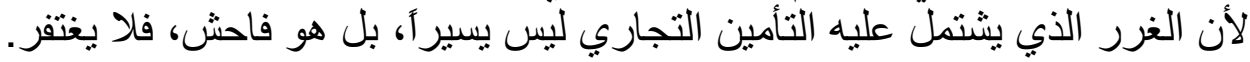
عـالمسابقات التجارية المشتملة على غرر يسير :

\section{أولا : تعربذ بذ المسابقات التنجارية:}

المسابقة في اصطلاح الفقهاء: "أن يسابق الرجل صاحبه في الخيل أو الإبل ونحو ذللك"(')، ولْم يخرج هذا المعنى عن المعنى اللغوي.

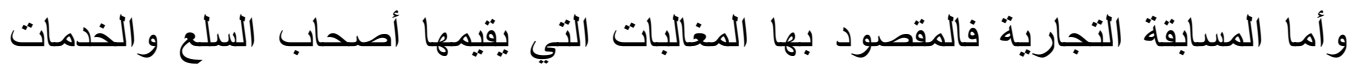

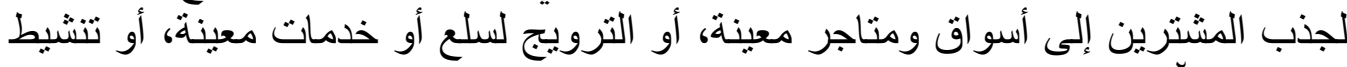

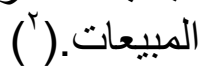

\section{ثانيا : أنواع المسابقات التجارية:}

المسابقات التجارية أنواع وأشكال، وقسّمها العلماء تقسيمات مختلفة، والذي يظهر أنه

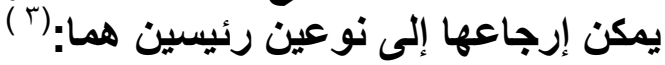
التوع الأول: المسابقات التي لا يشترط فيها الثراء، وذللك بأن تمنح الجهة المنظمة

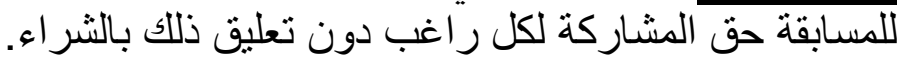

\section{ثالثا : التنفربه الفقهمي لهذا النو عم وحكمه:}

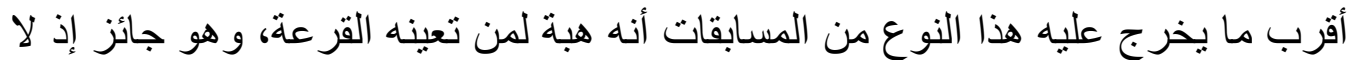

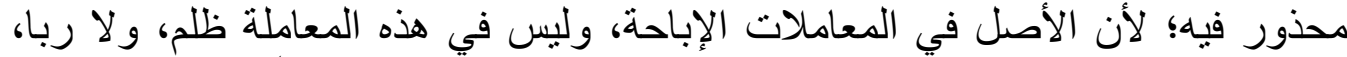

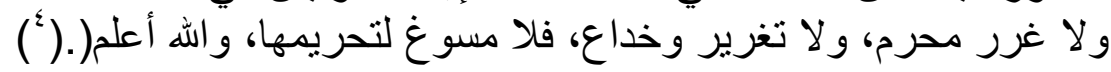

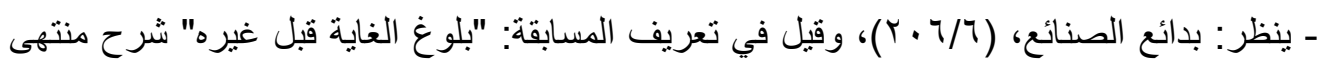

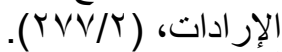

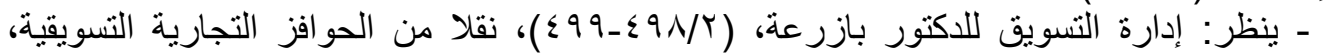

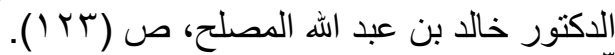

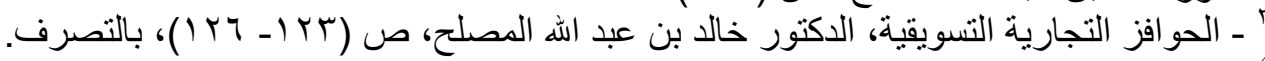
؛ - ينظر: المرجع السابق، ص (10. (10). 


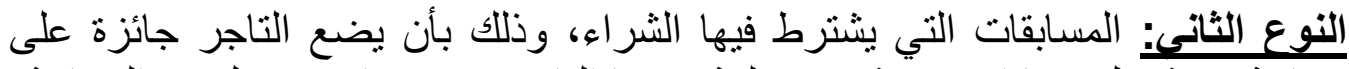
مسابقة لا يشترك فيها إلا من يشتري سلعة يبيعها التاجر ومن عداه لا يدخل في المسابقة.

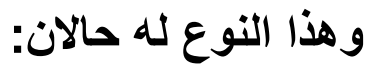

الحالة الأولى: أن تكون الجائزة مؤثرة في السعر، بحيث إن التاجر رفع السعر مقابل

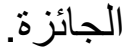

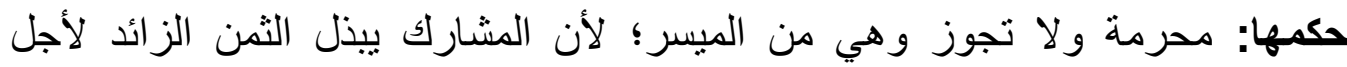

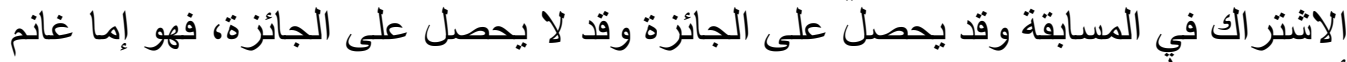

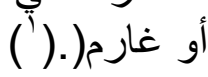

الحالة الثانية: ألا يكون للجائزة أثر في السعر و لا يز اد في ثمن السلعة على سعر المثل

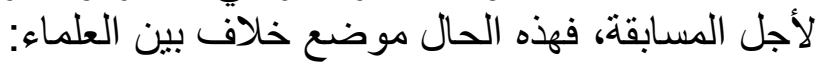

القول الأول: وهو القول بالتفصيل: فان كان قصد المستهلك السلعة لحاجته إليها فهذا

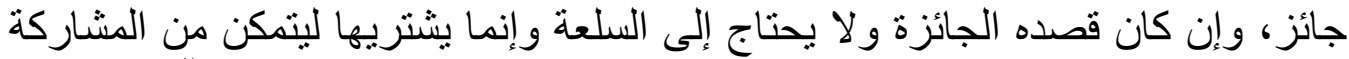

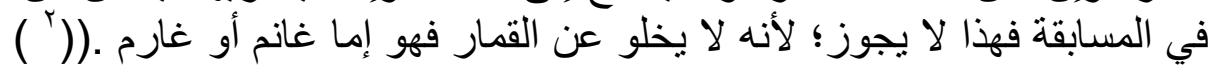

القول الثاني: هذا النوع من المسابقات محرم، لا يجوز استعماله و لا المشاركة فيه (.(") وجه تخريج المسألة على القاعدة :

إذا قلنا بتحريم المسابقات التجارية فلا تطبق القاعدة على هذه المسألة حيث لم يغتفر ما لفاء

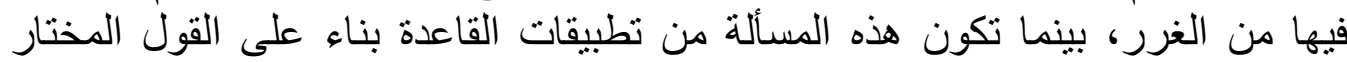

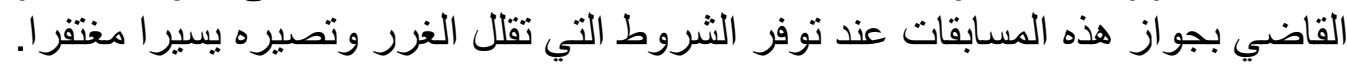

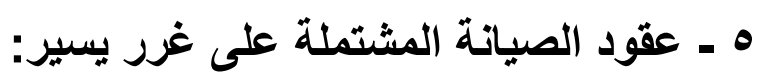

الصيانة في الاصطلاح هي: "مجموعة الأعمال اللازمة لبقاء عين على الحالة التي

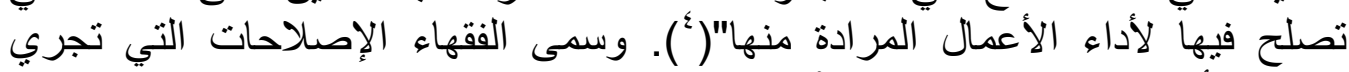

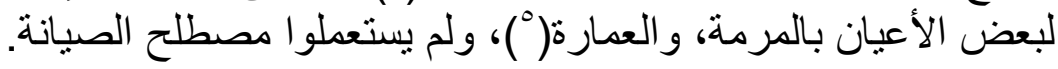

- ينظر: المرجع السابق، ص (9 (1)، و المعاملات المالية المعاصرة، خالد بن علي المشيقح، ص

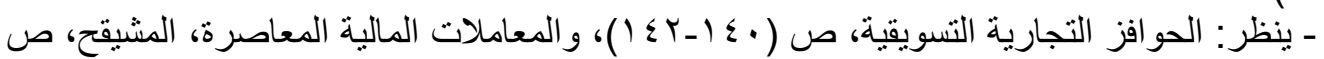

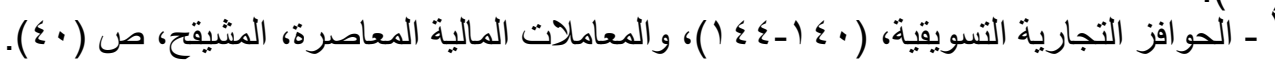

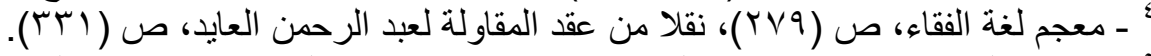

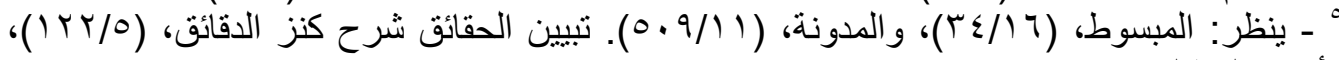




\section{التكبيف الفقهمي لعقد الصيانة:}

الصيانة بنو عيها إما أن تكون عقداً مستقلا، أو تابعاً لعقد آخر، فإن كانت الصيانة تابعة الصفان

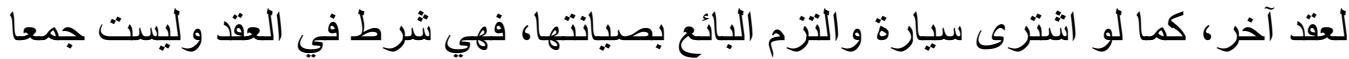

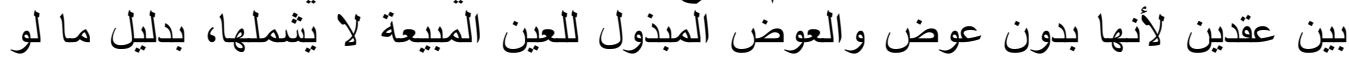

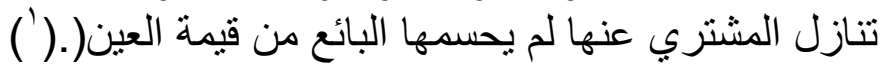

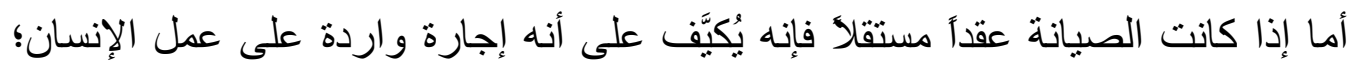

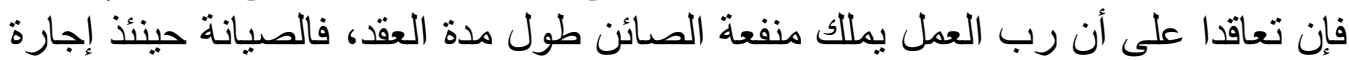

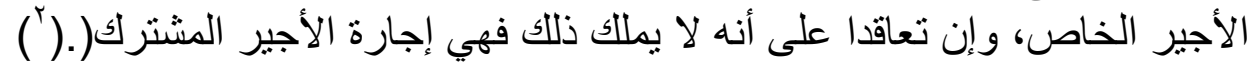

\section{هكم عقد الصبانة:}

يختلف حكم عقد الصيانة باختلاف صوره، ويتصور وقوع هذا العقد على الصور التالية:

الصورة الأولىي: أن تكون الصيانة تابعة لعقد آخر، فهي حينئذ شبيهة بالضمان من البائع،

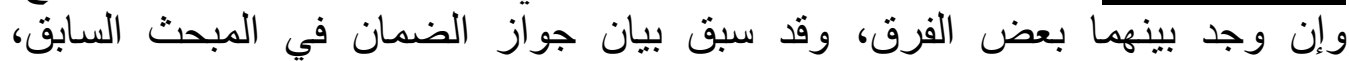

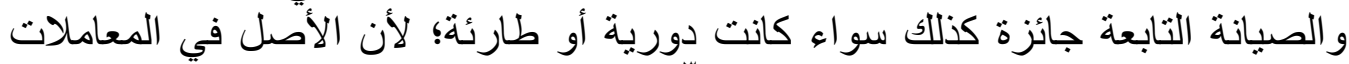

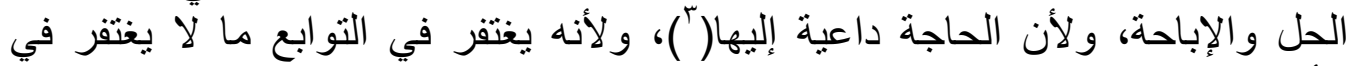

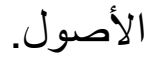

الصورة الثانية: التفقد الدوري بعقد مستقل، بحيث يتفق على مواعيد الصيانة وماذا

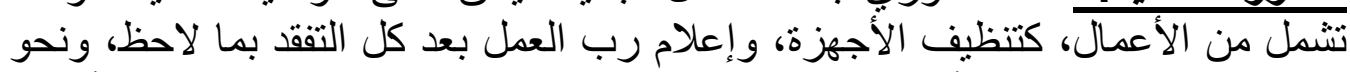
ذللك، فهذا العقد جائز؛ لأن العمل هنا معلوم لا جهالة فيه فيصح الاتفاق على أجرته

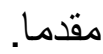

أمـا إن اشتمل العقد على إبدال المتلفات فله حالتان: الحالة الأولىي: أن يعلم وقت إبدالها سلفأ فيصح العقد لعدم الجهالة.

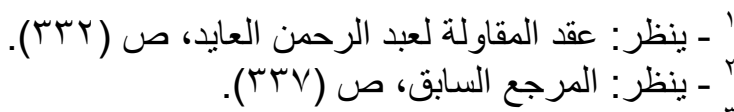
r - ينظر: الحوافز التجارية التسويقية، ص (YV) (YVY_YVO). 
الحالة الثانية: ألا يعلم وقت إبدالها سلفَّ ولا يمكن التنبؤ به، فلا يصح العقد حينئذ لجهالة

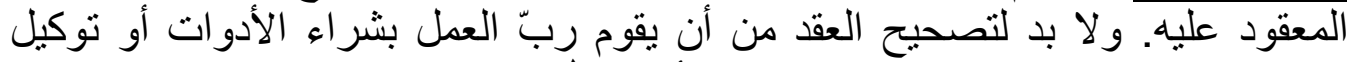

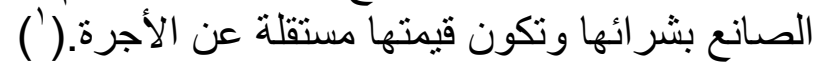

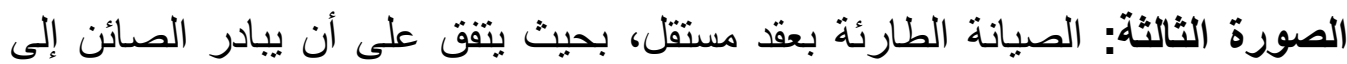

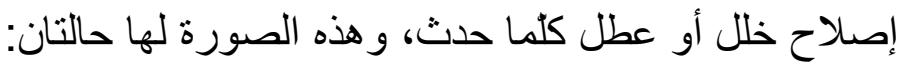

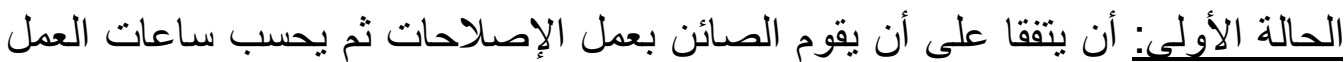

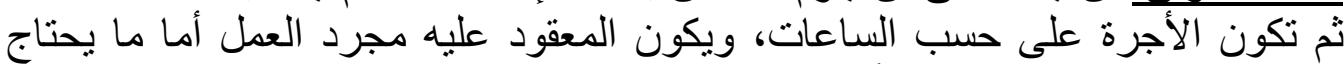

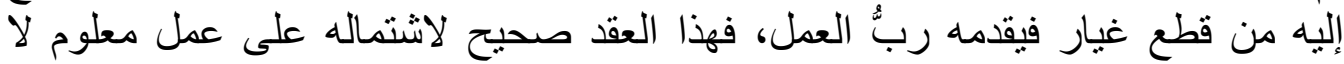

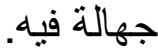

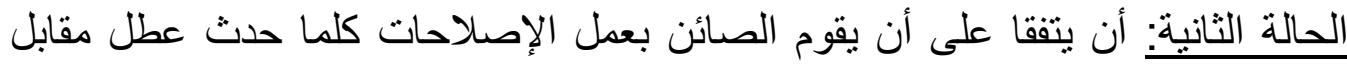

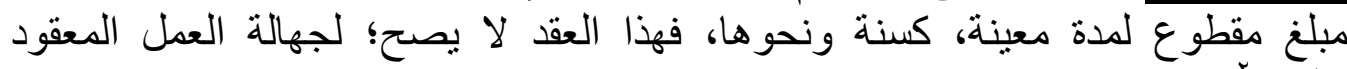
() مليه. () ملن

\section{وجه تنفربه المسألة على القاعدة:}

تبين مما سبق أن عقد الصيانة إذا كان تابعأ لعقد آخر غيرَ مقصودٍ بذاته فإنه يصح، وما إنها

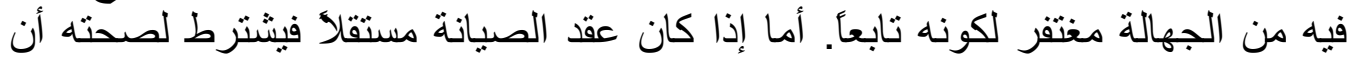

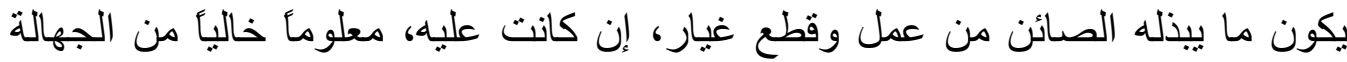
الفاحشة المفسدة للعقود. فصور عقود الصيانة الجائزة سابقة الذكر من تطبيقات القاعدة؛ لأن ما فيها من الغرر يسير ومغتود فئر.

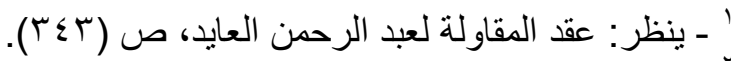

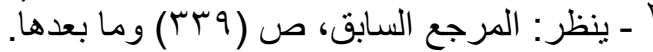




\section{المبحث الثالث}

\section{القاعدة الثالثة : ( بيع النجاسات يتبع الضهان )}

\section{المطلب الأول \\ صبيز القا عدة وبيان معناها}

الأصل عند الحنفية أن جواز البيع يتبع الضمان. فكل ما كان مضمونأ بالإتلاف جاز

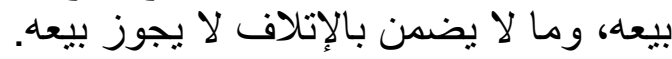

وعند الإمام الثافعي رحمه الله: جواز البيع يتبع الطهارة فما كان طاهرآ جاز بيعه وما

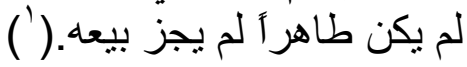

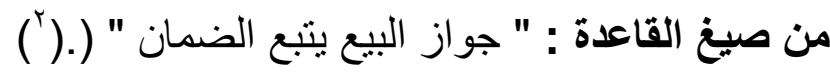

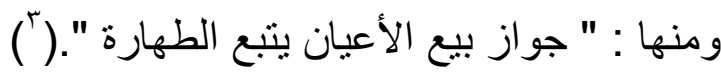

ومعنى " جواز بيع الأعيان يتبع الطهارة " أي تكون الطهارة فيه شرطان لهان من جملة الثروط.

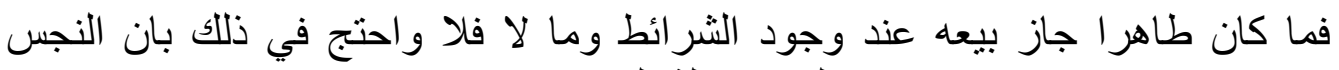

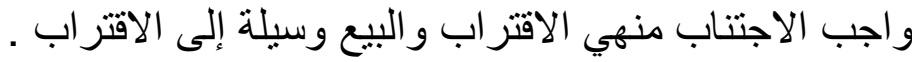
المطلب النغانيى

\section{أراء الفقهاء فيى شرططهارة الهبيه}

اختلف العلماء في اشتراط طهارة المبيع إلى رأيين : نص المالكية و الشافعية و الحنابلة على أنه يشترط في العوض طهارة عينه، و القدرة على (") نسليمه. (1)

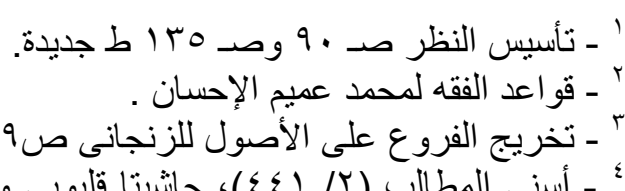

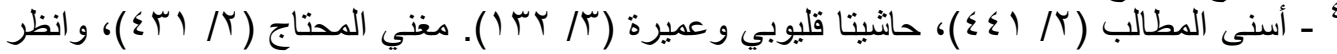


وقد اقتصر خليل على اشتراط كون العوض معلومًا، ولم يذكر بقية الثروط، فقال

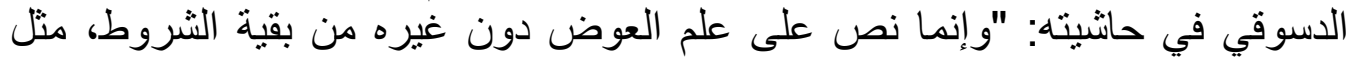

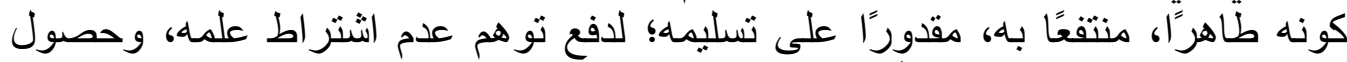

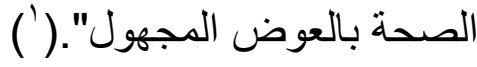

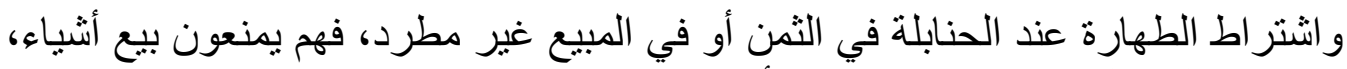
ويعللون ذلك بالنجاسة، ويجيزون بيع الثياء الثياء مع حكمه لها في بالنجاسة.

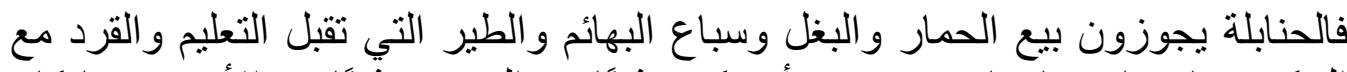

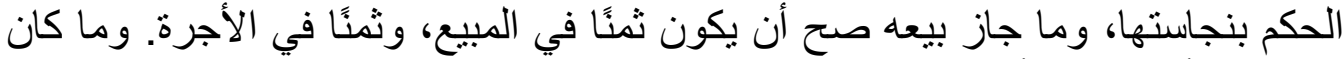
ثمنًا في الأجرة صنح أن يكون عوضنًا في الجعالة.

ويمنعون بيع السرجين النجس.

قال في المغني: "و لا يجوز بيع السرجين النجس، وبهذا قال مالك و الثافعي، وقال أبو

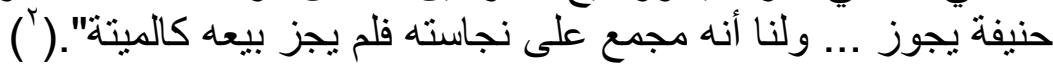

ويعبر الحنابلة أحيانًا عن هذا باشتر اط إباحة الاتتفاع، ويقصدون به إخراج شيئين:

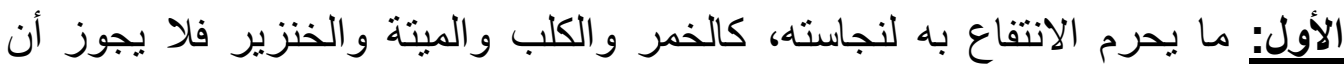

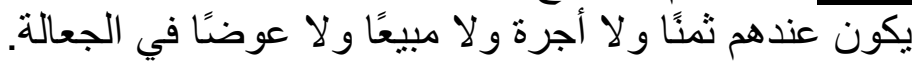

الثانى: ما يحرم الانتفاع به لحرمته، و إن كان طاهرًا كآلات اللهو، والأصنام. و أما اشتراط القدرة على التسليم فهو شرط عندهم في الجعالة قياسًا على اشتر اطه في

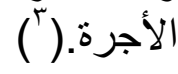

والر أي الثاني : رأى بعض الحنفية وهو المعتمد عندهم أنه لا يشترط طهارة المبيع . جاء في مجلة الأحكام : " الفصل الأول في حق شروط المبيع 101 وأوصافه مادة Vو 19 يلزم أن يكون المبيع 101 موجودا مادة 191 بلزم أن يكون المبيع 101 مقدور التسليم

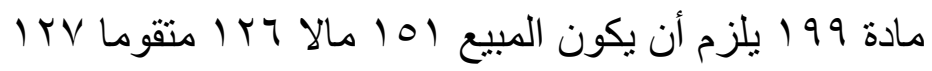


مادة . . ب يلزم أن يكون المبيع 101 معلوما عند المشتري (71

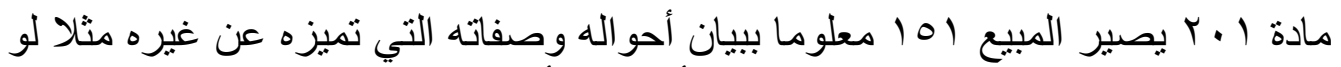

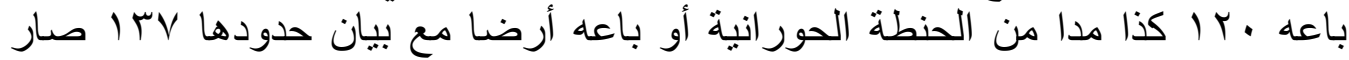

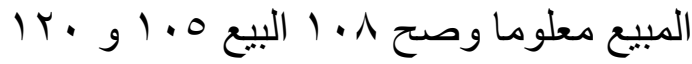

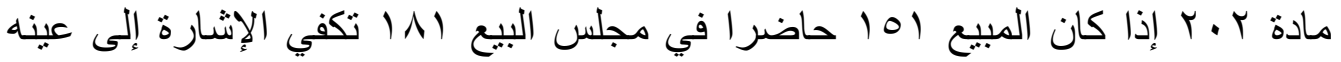

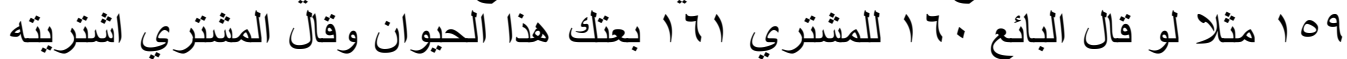

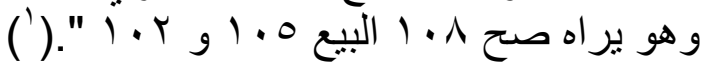

فلم يذكروا من شروط المبيع أن يكون طاهرا ، وإنما شرطوا :

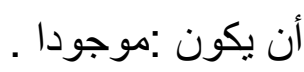
ومقدور التسليم . وأن يكون مالا متقوما . وأن يكون معلوما عند المشتري .

وبناء على ما سبق يتبين : أن ما كان نجسا ولا ينتفع به لا يجوز بيعه ، و وما كان نجسا

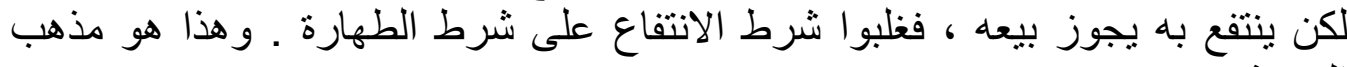
الحنفية .

\section{المطلب النالن}

\section{التطبيقات على القاعدةة}

ا 1 - بيع فضلات الحيوانات :

إن كثيرا من الدول تنشئ المسالخ في ضواحي المدن، ليجري ذبح الحيوانات المأكولة

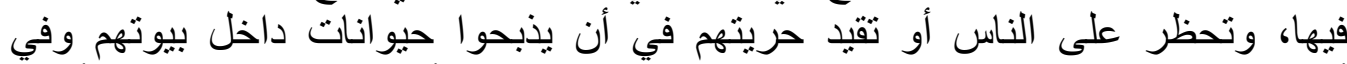

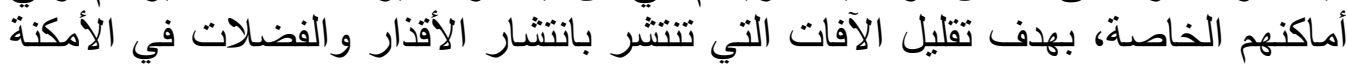

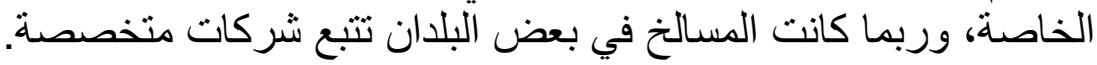


و المسالخ تطبق القواعد العلمية في جمع فضلات الذبائح والتخلص منها بحرقها أو توفي

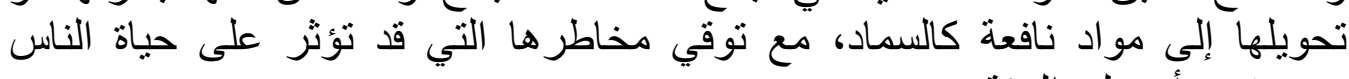
وصحتهم، أو على البيئة.

و الهيئات القائمة على المسالخ تكون أعرف وأقدر على ذلك من عامة الناس لو ترك

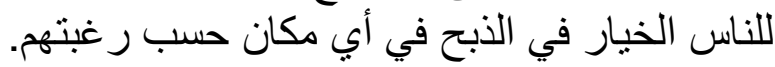

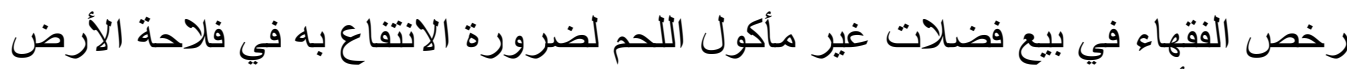

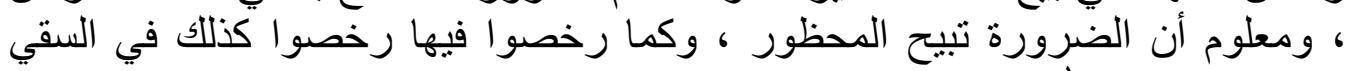

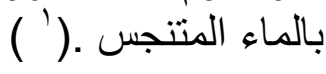

\section{r - بيع دم الحيوانات المذبوحة : ب}

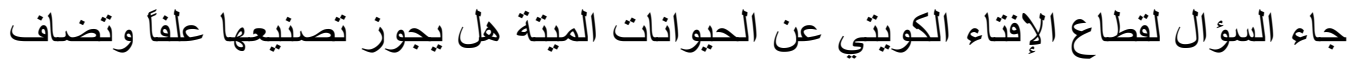

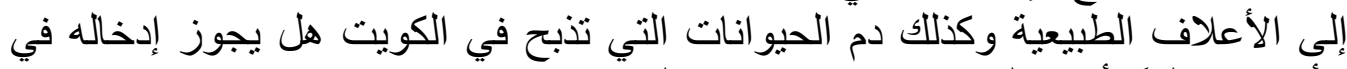
الأعلاف علمأ بأن هنالك فو ائد من ور اء هذاء المشروع وهي:

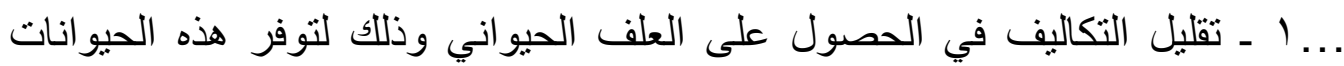
الميتة و الحصول عليها بسهولة.

الأ...

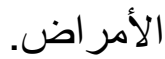

وقد حضر المستفتي في هذه الجلسة و أفاد بأن لاى شركته فكرة لإنشاء مصنع لعلف الدو اجن و هذا المصنع يعتمد في تصنيع العلف على المو الم اد التالية:

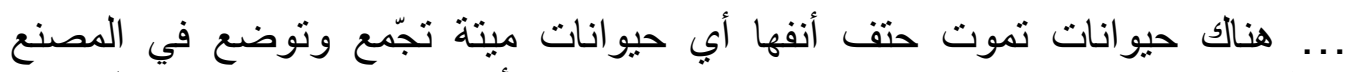

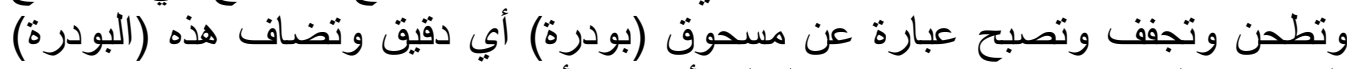

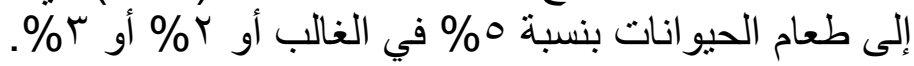

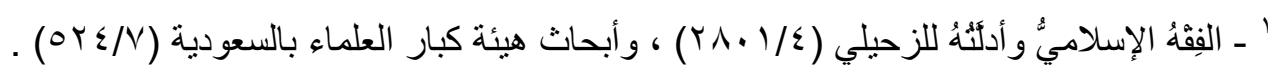




\section{وقد أجابـت اللجنة بـما بلي؟:}

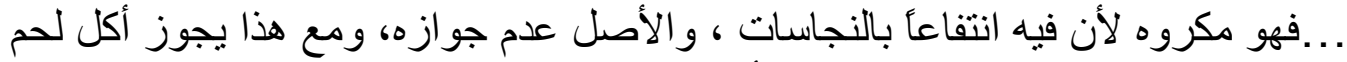

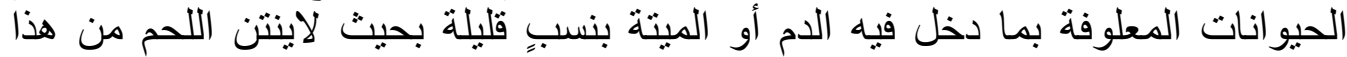

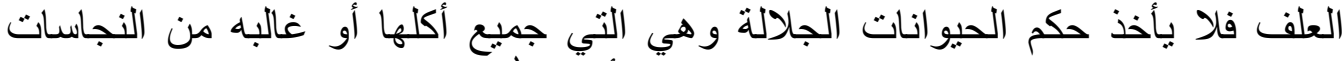

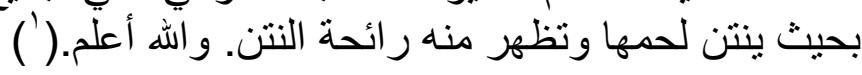

ومضمون الاجابة انه يجوز مع الكراهة .

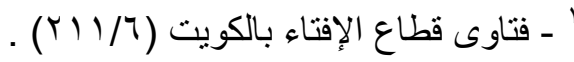




\section{الاببمث الرابع}

\section{القاعدة الرابعة : ( بيع المعدوم يتبع الغرد ) \\ المطلب الأول}

\section{تعربف المعدوم وذكر صيخ القا عدة}

أولا : :تعريف المعدوم :

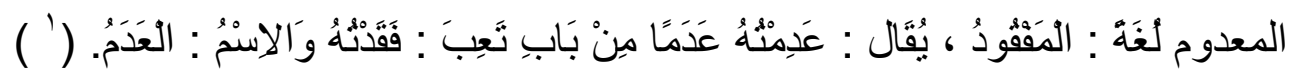

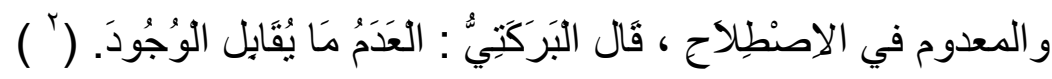

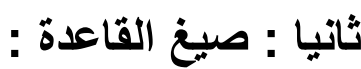

وقد عبر الفقهاء عن هذه القاعدة بقولهم : " بيع المعدوم باطل ".(")

وعبر بعضهم بقوله : " شر اء المعدوم باطل ".(")

و عبر بعضهم بقوله : " تمليك المعدوم و الإباحة له نو عان : أحدهما : أن يكون بطريق

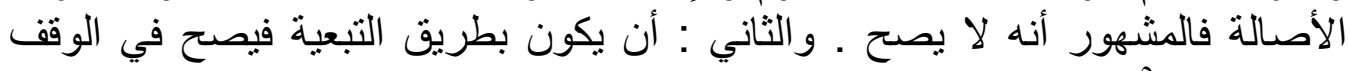

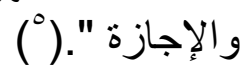

وعبر بعضهم بقوله : " المعدوم لا يكون محلا لإضافة العقد إليه ".(")

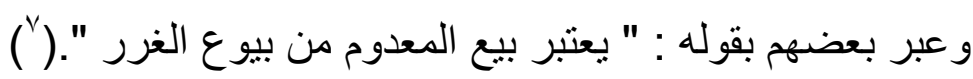

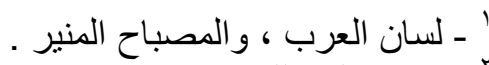

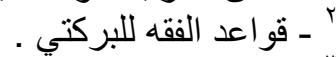

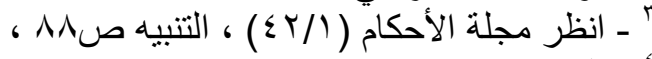

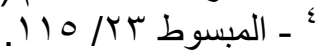

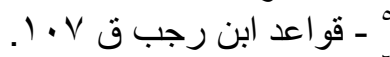

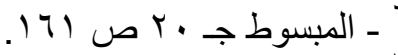




\section{معنى القا عدة :}

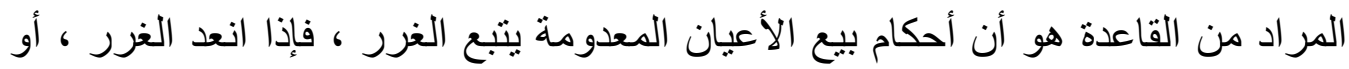

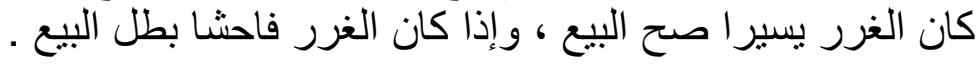

\section{المطلب الناني}

\section{مكم ببيه ما لا بملك}

اشترط جمهور العلماء لانعقاد العقد أن يكون محل العقد موجوداً وقت التعاقد، فلا يصح

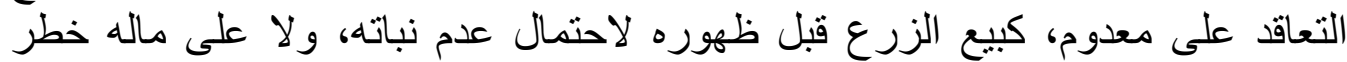

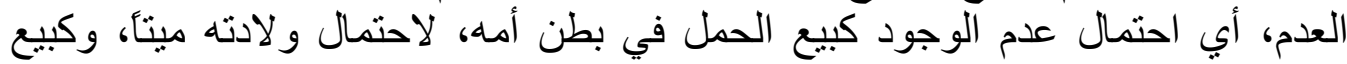

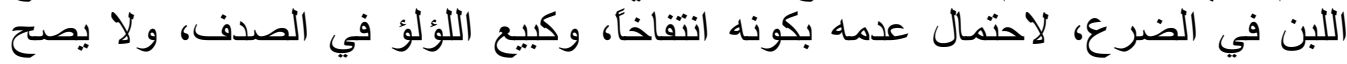

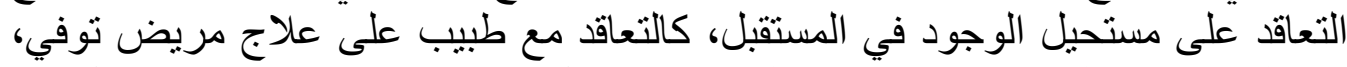

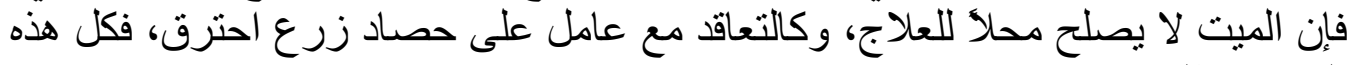
العقود باطلة.

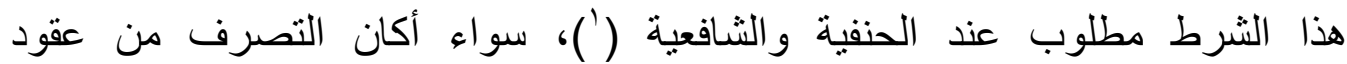

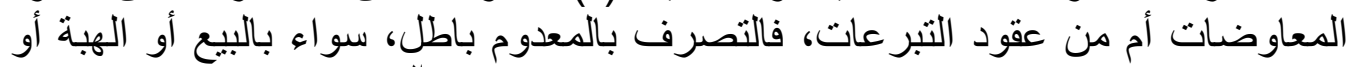

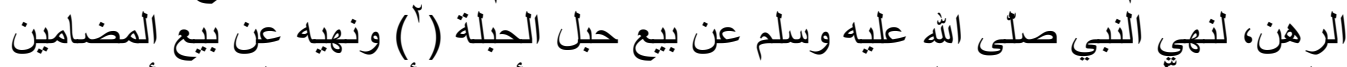

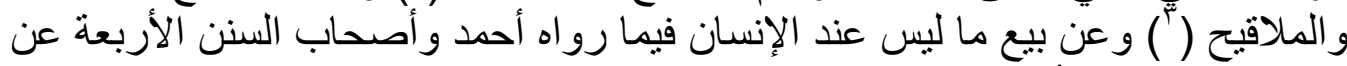

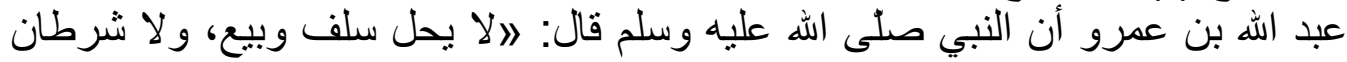

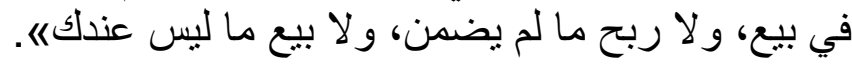

و واستثنى هؤلاء الفقهاء من قاعدة المنع من التصرف بالمعدوم عقود السلم والإجارة

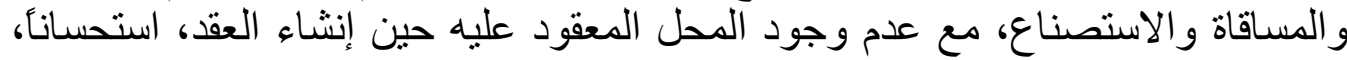

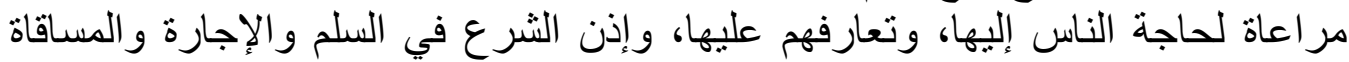

ونحوها.

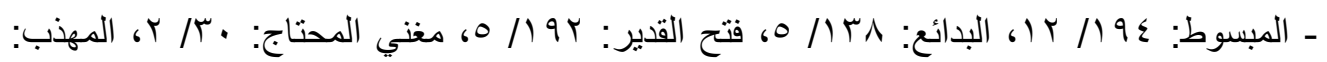
1 1 ال

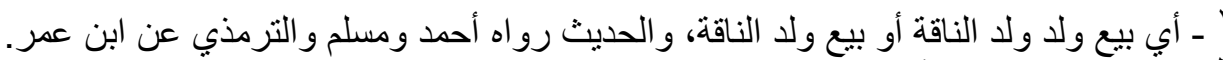

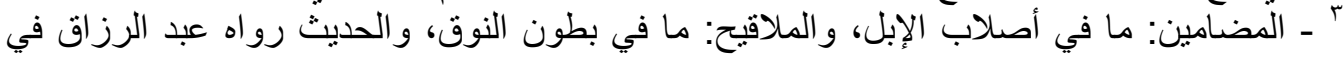


و اكتفى المالكية باشتراط هذا الثرط في المعاوضات المالية، دون التبرعات كالهبة

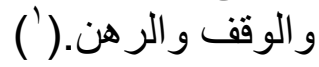

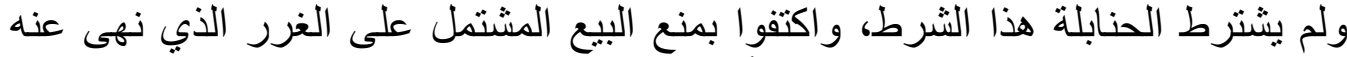

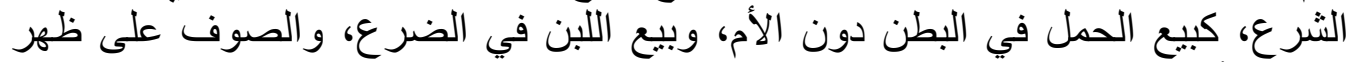

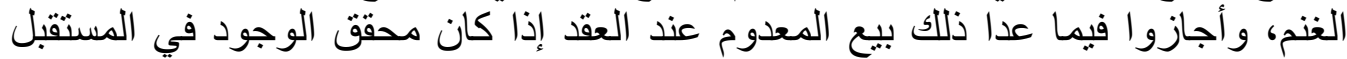

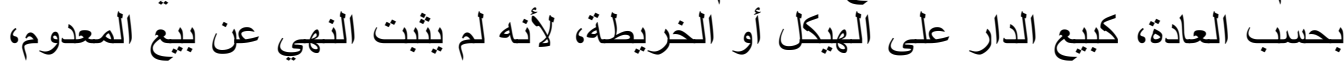

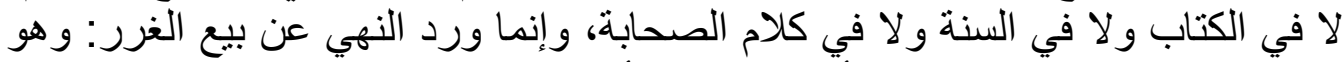

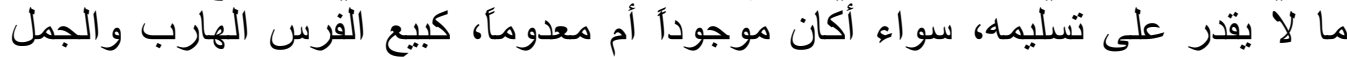

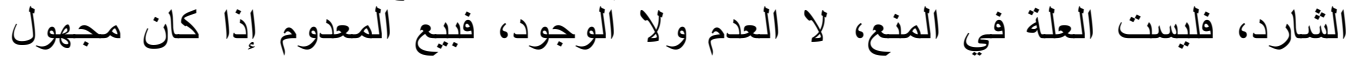

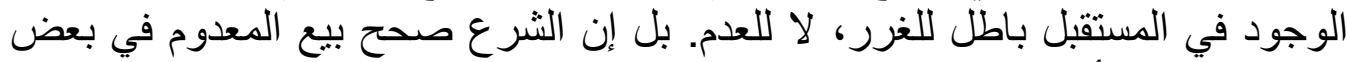

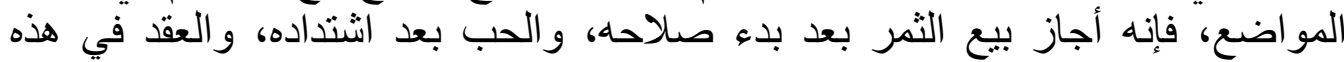

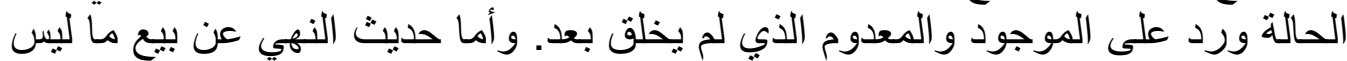

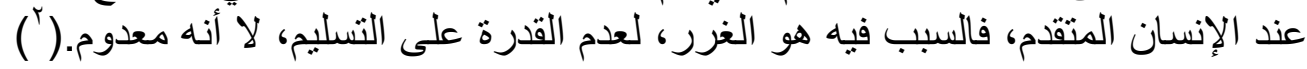

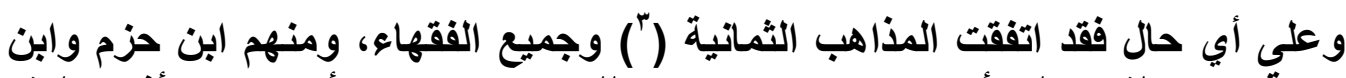

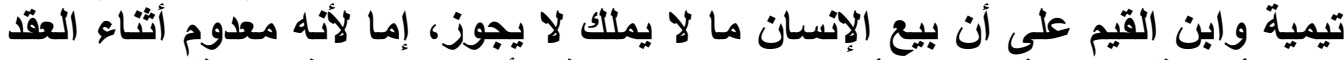

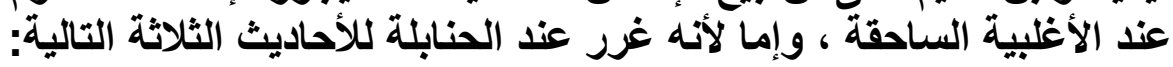

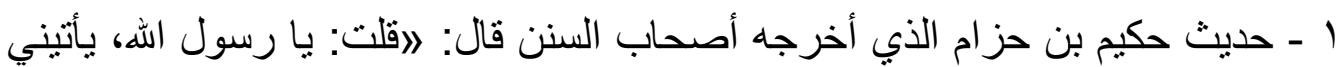

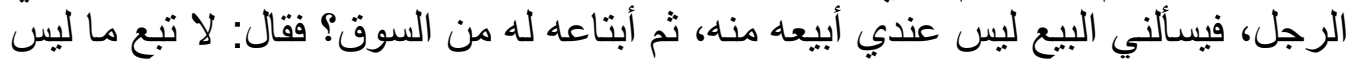

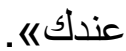

r - حديث عبد الله بن عمرو المتقدم الذي أخرجه أحمد وأصحاب السنن الأربعة

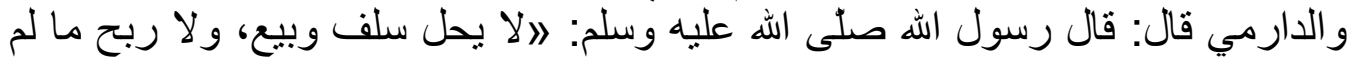
يضمن، ولا بيع ما ليس عندكاله

ب - حديث أبي هريرة الذي أخرجه مسلم وأحمد وأصحاب السنن: لانهى رسول الله

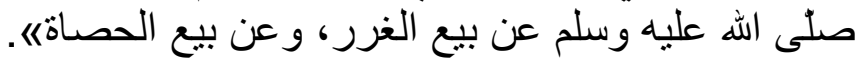

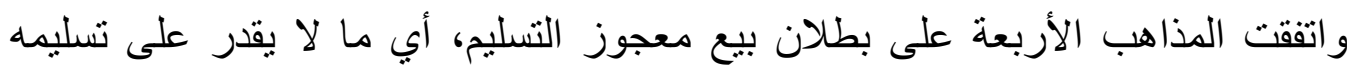

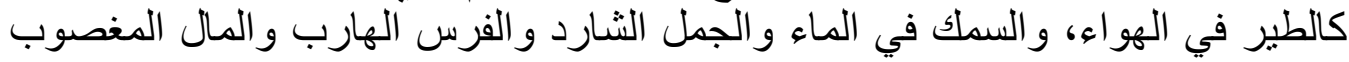

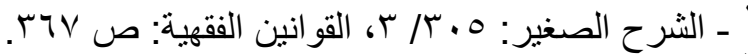

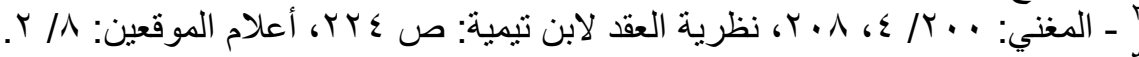

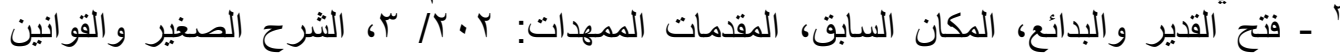

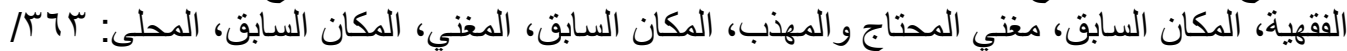

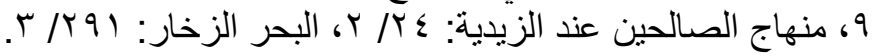


في يد الغاصب، وكبيع الدار أو الأرض تحت بد العدو، لأن النبي صلى الله عليه وسلم -

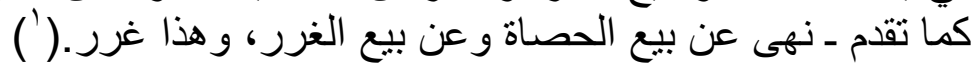
و اتفق الفقهاء على عدم صحة بيع الغرر، كبيع اللبن في الضرع، و الصوف

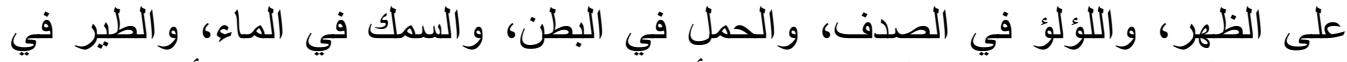

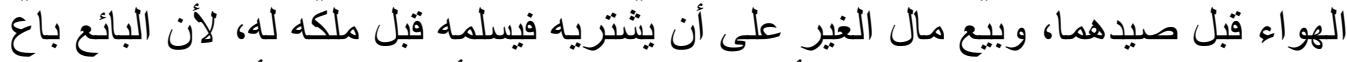

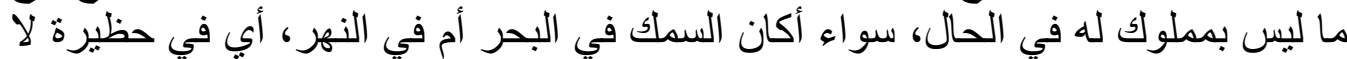

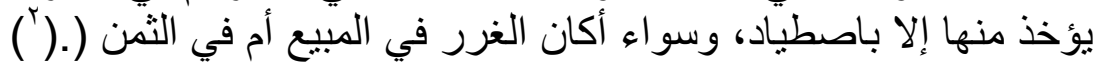

\section{المطlll}

\section{تعليل منــ ببيم المعدوم}

قال ابن القيم : " فصل خطأ من أطلق أن بيع المعدوم لا يجوز وأما المقدمة الثانية وهي أن بيع المعدوم لا يجوز فالكلام عليها من وجهين :

أحدهما : منع صحة هذه المقدمة إذ ليس في كتاب الله ولا في سنة رسول الله ص - ورلا

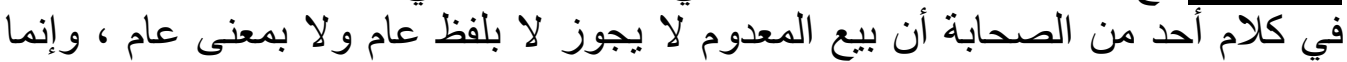

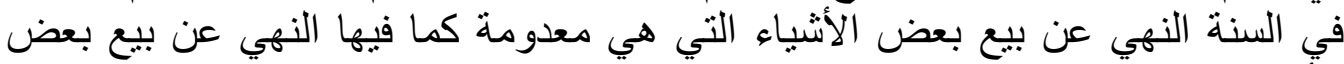

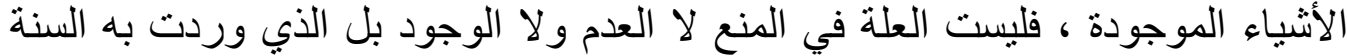

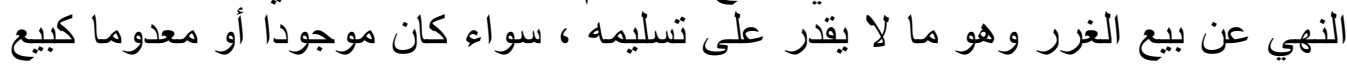

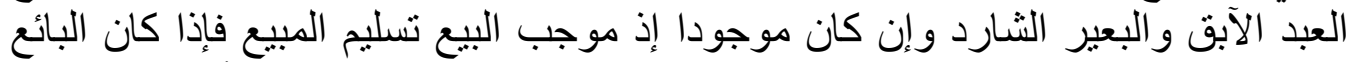

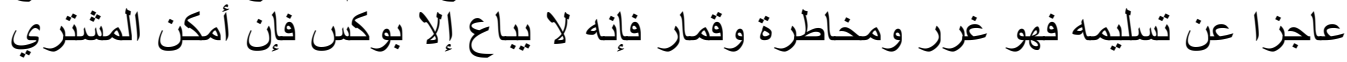
تسلمه كان قد قمر البائع و إن لم يمكنه ذللك قمره البائع....

الوجه الثانى : أن نقول بل الثرع صحح بيع المعدوم في بعض المواضع ، فإنه أجاز

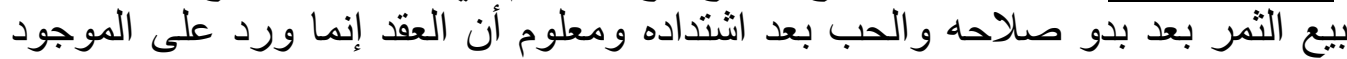

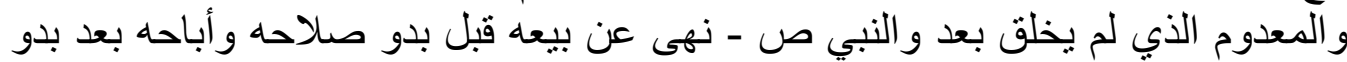

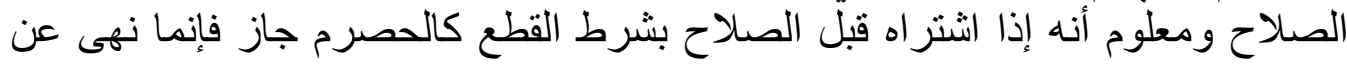

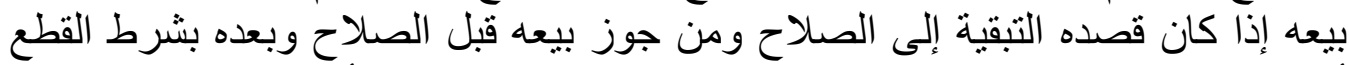

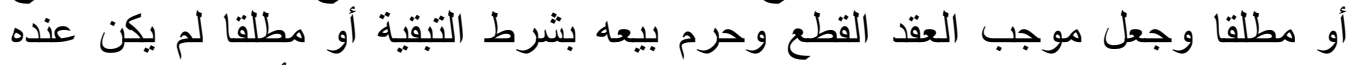
لظهور الصلاح فائدة ولم يكن فرق بين ما نهى عنه من ذاعه ذلك وما أذن فيه فإنه يقول

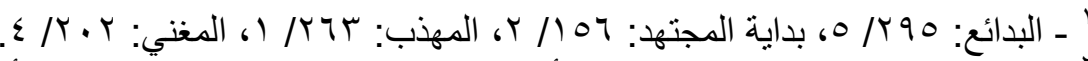

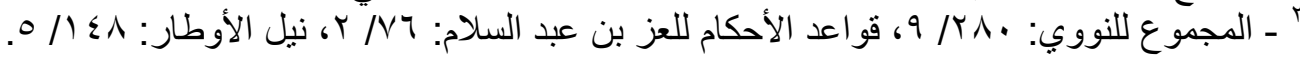


موجب العقد التسليم في الحال فلا يجوز شرط تأخيره سواء بدا صلاحه أو لم يبد. و الصواب قول الجمهور الذي دلت عليه سنة رسول الله ص - و القياس الصحيح ...

وقد اتفق الأئمة على صحة بيع الأمة المزوجة و إن كانت منفعة البضع للزورج ولم ولم تدخل

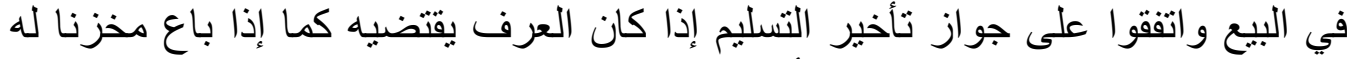

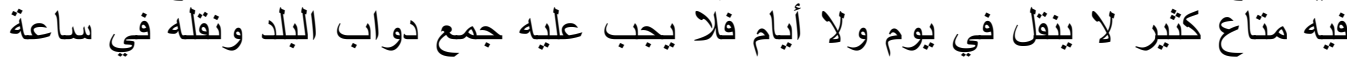

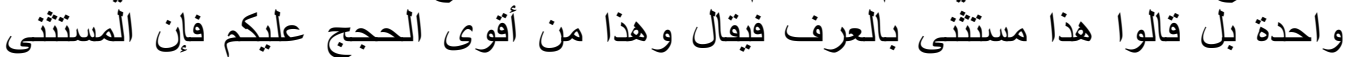

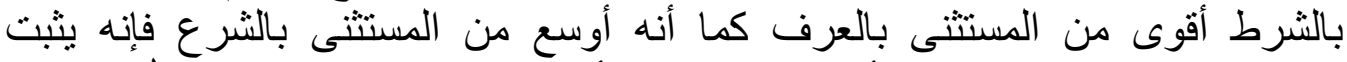

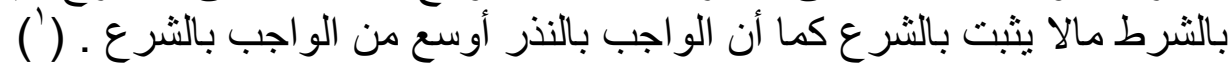

\section{المطلب الرابـم}

\section{التطب بقات على القاعدة}

ا

جاء في فتاوى بيث التمويل الكويتي فتوى رقم ( ب I )

: Jling

يجرى العمل في الأسواق العالمية للمعادن أنه إذا رغب تاجر في شراء معدن معين

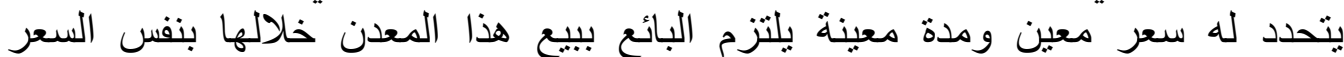

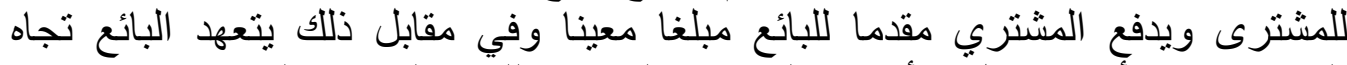

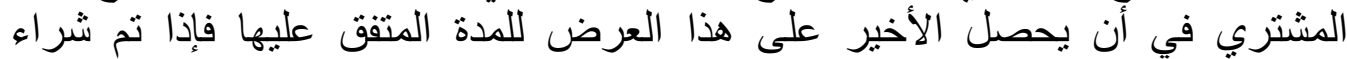

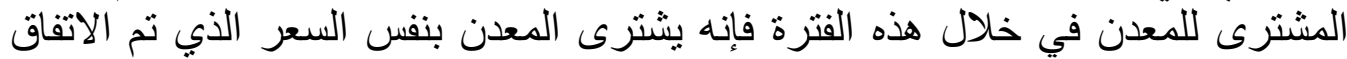

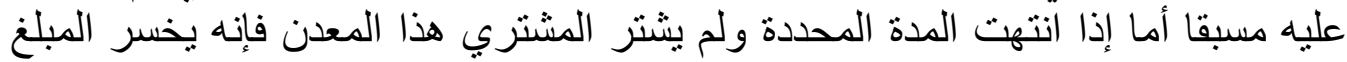

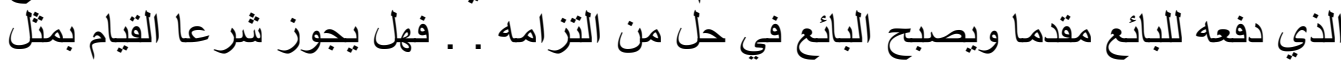

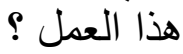

\section{1}

إن ما يجرى عليه العمل في الأسواق العالمية بالنسبة لبيع المعادن بصورة شاملة للذهب

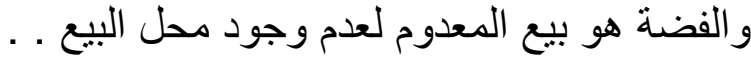


فإن كان محل البيع معدنا من الذهب أو الفضة فلا يجوز دخول الأجل في الصفقة مطلقا

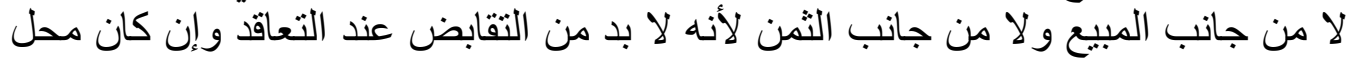

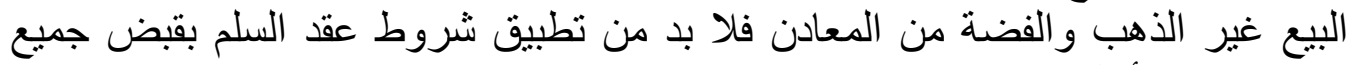

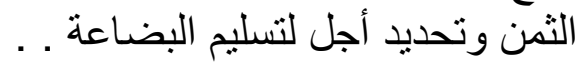

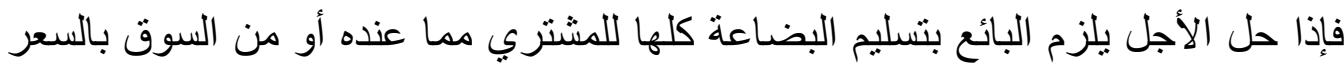

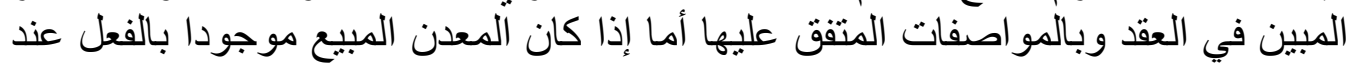

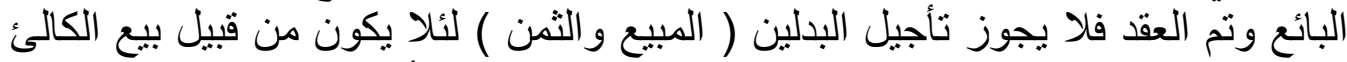

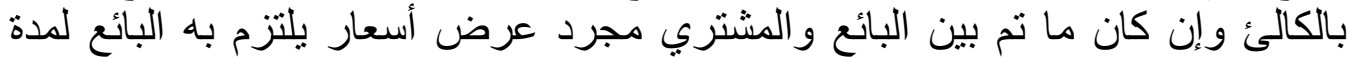

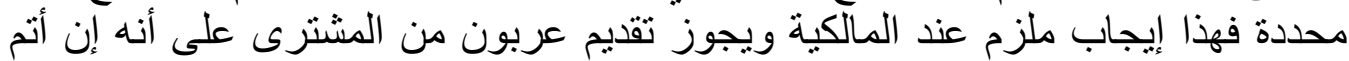

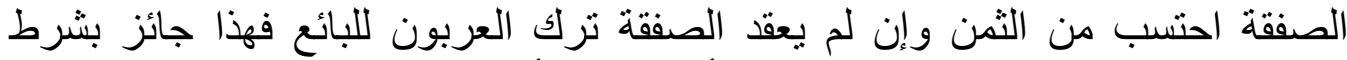

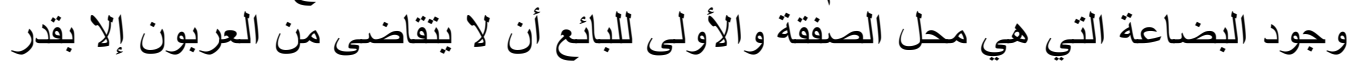

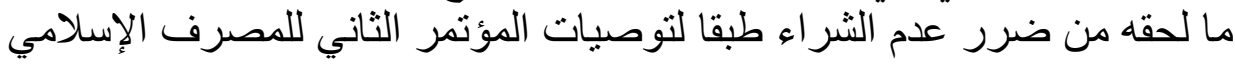

\section{r - بيع الثقق التي لم يكتمل بناؤها : - ب}

جاء في بيت التمويل الكويتي فتوى رقم ( بسM )

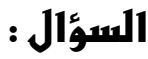

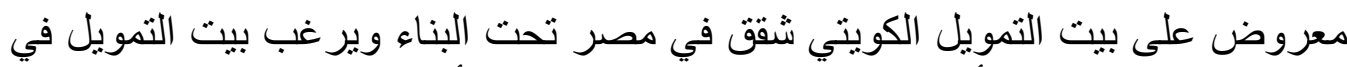

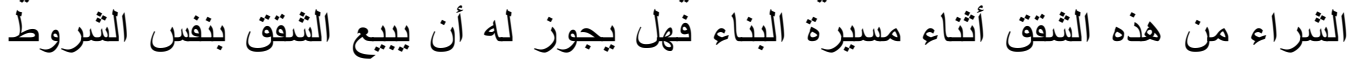

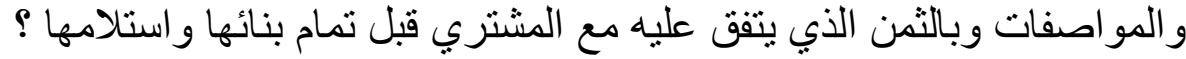

البمواب :

لا يجوز بيع الثقق المشتراة بعقد استصناع بنفس الثروط و المواصفات وبالثمن الذي باتي

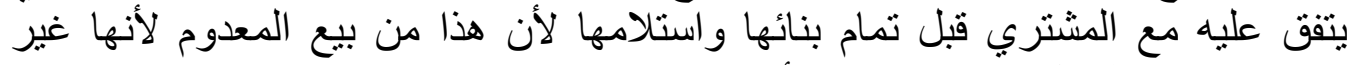
موجودة فعلا بالثكل الذي تباع على أساسه . r - بيع كوبونات التغذية المقدمة من الجامعة : جاء في فتاوى الثبكة الإسلامية

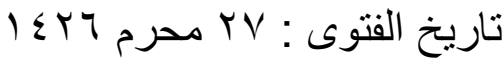




\section{السؤوال :}

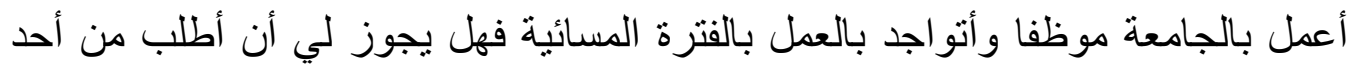

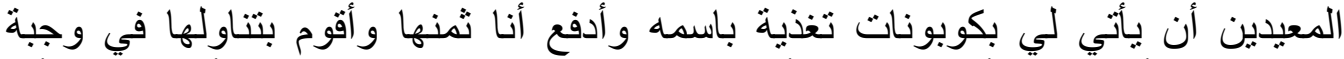

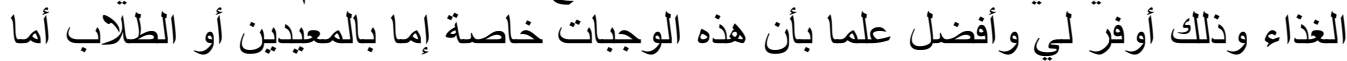
الموظفون فليس لهم وجبات ربما لأن غالبية الموظفين ينصرفون قبل الثبان الثنانية ظهرا علما بأنني أعمل بالمكتبة ولكن يشرط لحصولي على وجبة مجانية أن أتواجد بالعمل ثلاث ساعات إضافية

$$
\text { أفيدوني جز اكم الله خير ا فأنا في حيرة من أمري ؟ }
$$

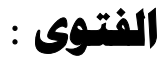

الحمد لله و الصلاة و السلام على رسول الله و على آله وصحبه، أما بعد:

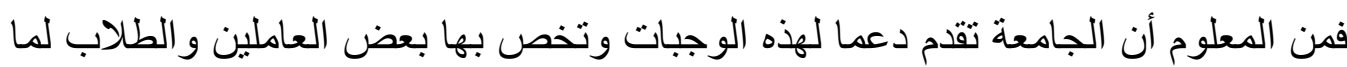

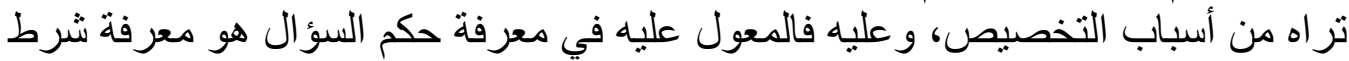

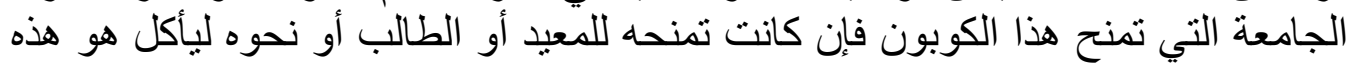

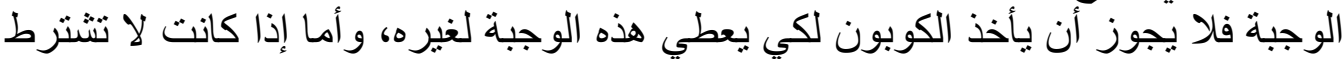

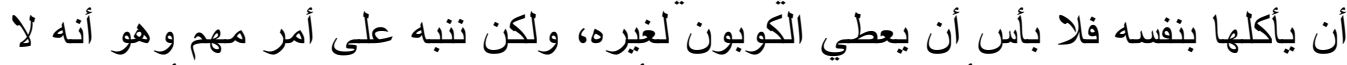

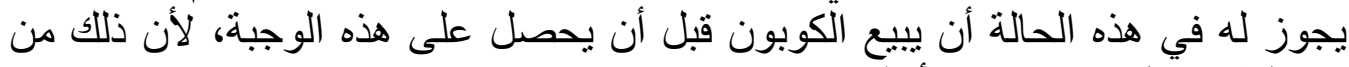
بيع الطعام قبل قبضه، و والله أعلم. 


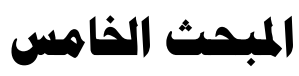

\section{القاعدة الخامسة : ( الأصل اتباع ها لا يستقل بنفسه لـا يستقل بنفسه ) \\ المطاب الأورل}

\section{صبغ القا عدة وببيان معناها}

عبر بعض الققهاء عن هذه القاعدة بصيغ مختلفة من هذه الصيغ :

قولهم : " التابع في الوجود تابع في الحكم إلا بدليل "( (')

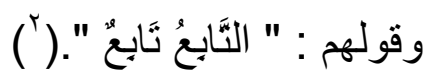

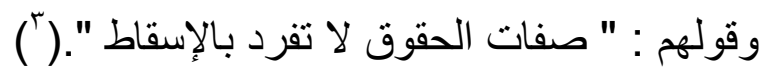

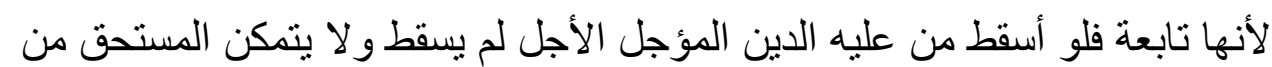

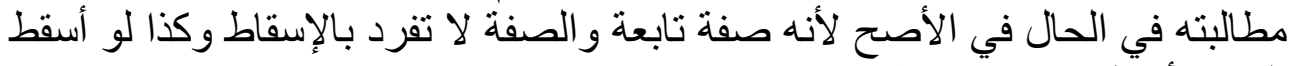

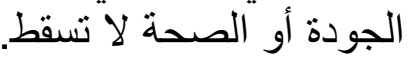

وقولهم : " التَّابعُ يَسْفُط بسُقوطِ المَنَبُوع ".

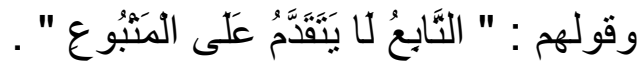

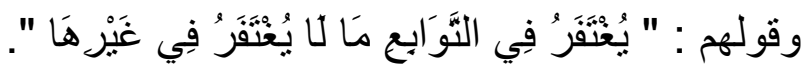

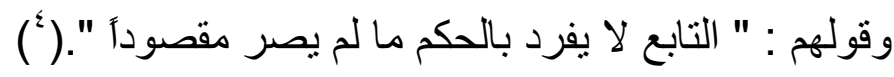

وقولهم : " التابع لا يستقل ".

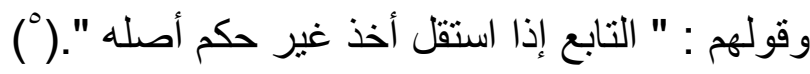

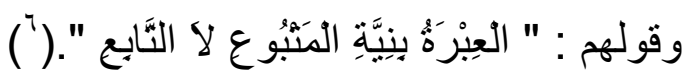

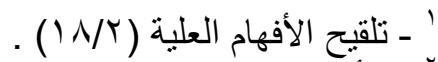

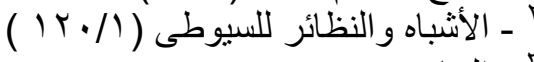

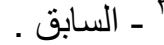

$$
\begin{aligned}
& \text { " - القو اعد للزرقا . } \\
& \text { " - مجمو عة الفو ائد البهية . }
\end{aligned}
$$

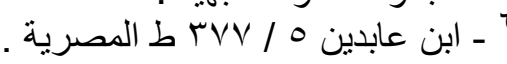




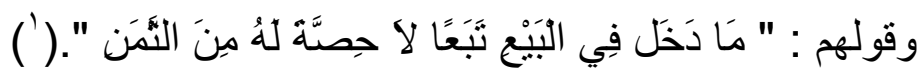

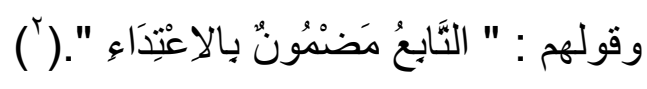

وقو لهم : "إذا بطل المتضمَّن بطل المتضمَّن." (")

وقولهم : "إذا بطل الثيء بطل ما في ضمنه".

وقولهم : "الفرع يسقط إذا سقط الأصل." (")

وقولهم : " الأصل أنه قد يثبت الثيء تبعأ وحكماً وإن كان يبطل قصدأ." ( )

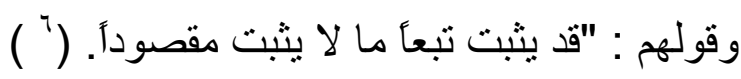

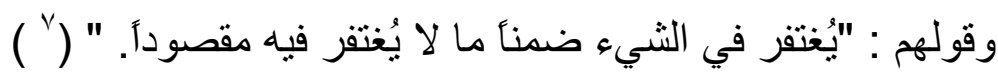

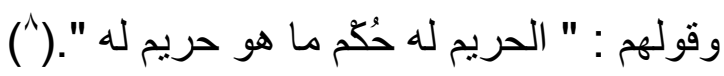

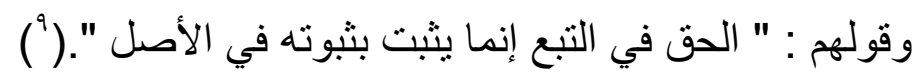

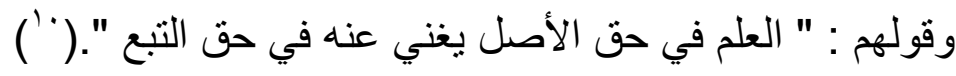

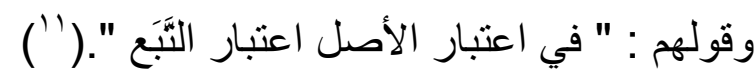

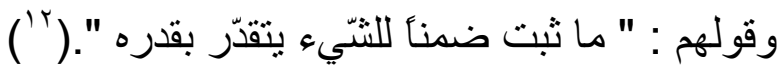

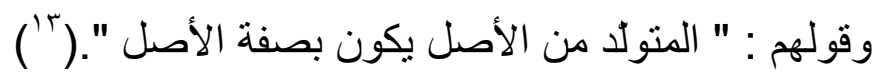

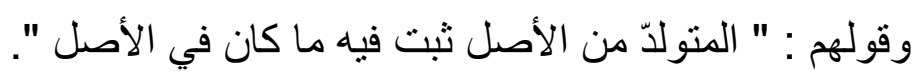

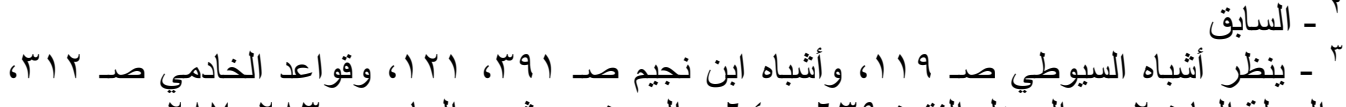

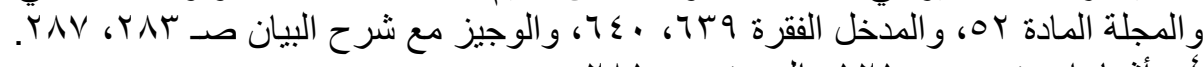

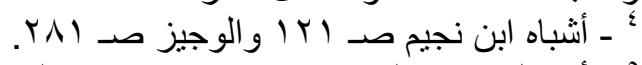

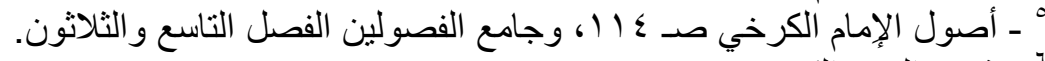

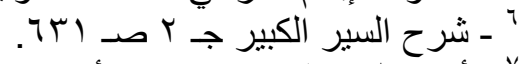

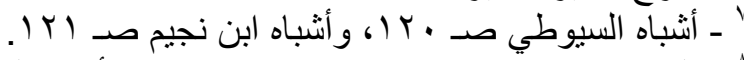

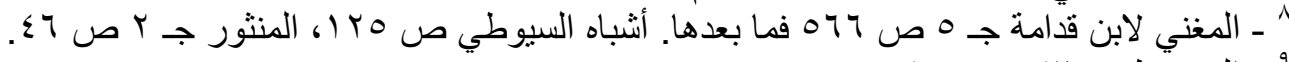

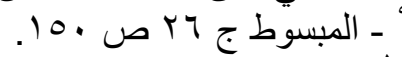

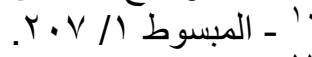

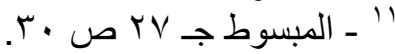

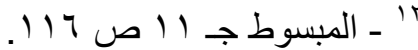

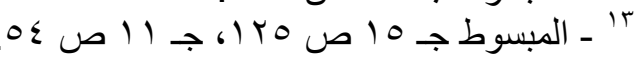




\section{وقولهم : " المتولد بملك بملك الأصل ".}

$$
\text { وقولهم : " المتولد من الأصل يثبت فيه ما كان في الأصل ".(') " (') }
$$

وقولهم : " هل يثبت الفرع والأصل باطل، وهل يحصل المسبّب والسّبب غير حاصل

\section{معنى القاعدة ومدلولها:}

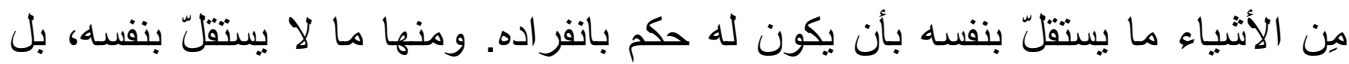

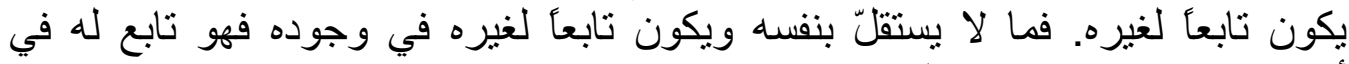
أحكامه، و لا يجوز لغيره إفر اده بالحكم.

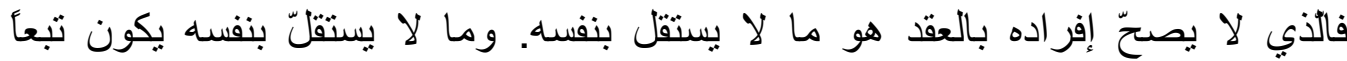

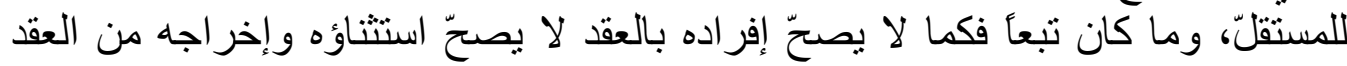
على متبو عه.

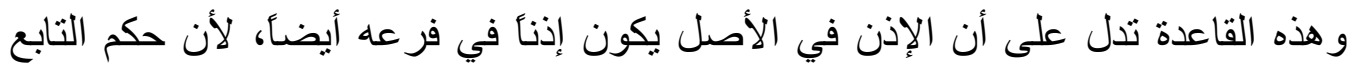

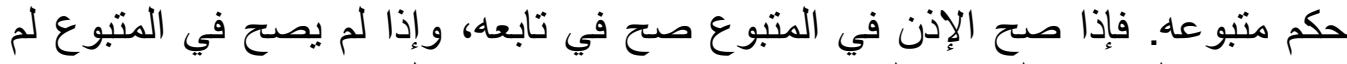

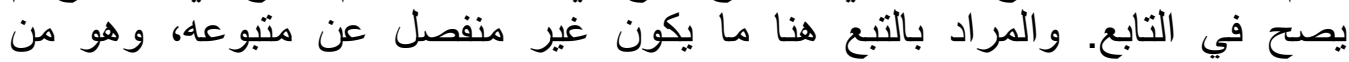
ضرور اته ولوازمه وإلا فلا يكون الاذن في المتبوع إذناً في التبع.

مثال ذلك :

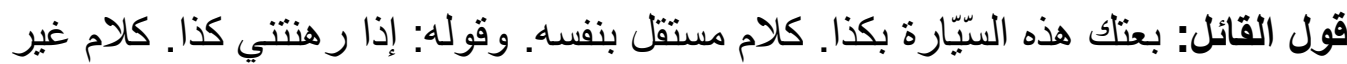

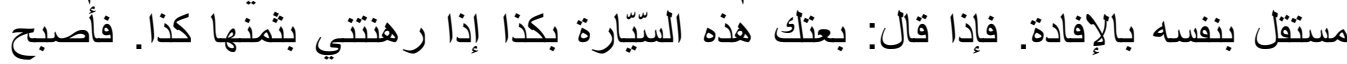

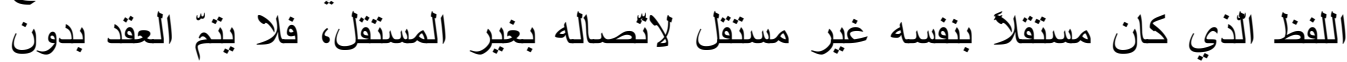
العبارتين معأ.

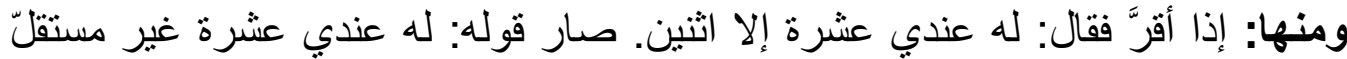

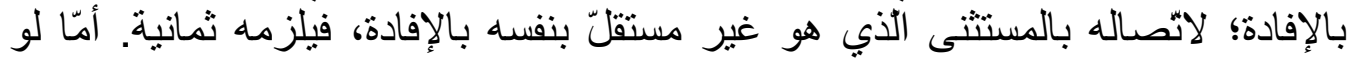
قال: له عندي عشرة. وسكت فيلزمه عشرة لاستقالال اللفظ بنفسه في الإفادة.

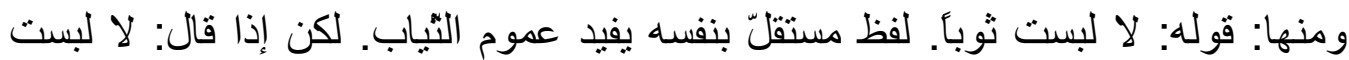

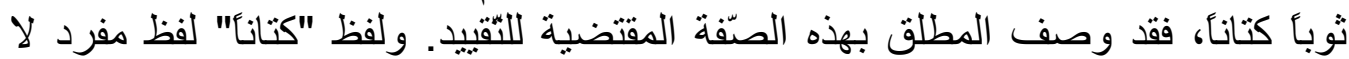
يستقلّ بنفسه.

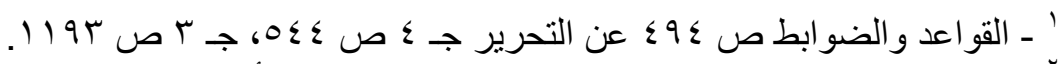

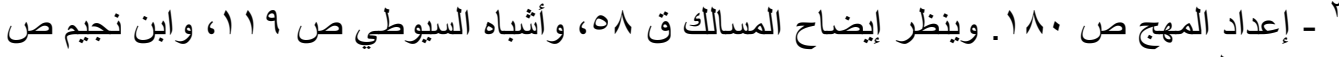




\section{المطالب الثانبي}

\section{النطبيقات المعاصرة للقاعدة}

من التطبيقات المعاصرة التي يمكن تخريجها على القاعدة : ـ أخذ الرسوم على إصدار البطاقات الائتمانية :

لم تكن جهات إصدار البطاقات الائتمانية تفرض رسومأ على حامل البطاقة في مقابل

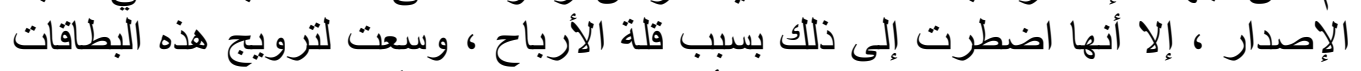

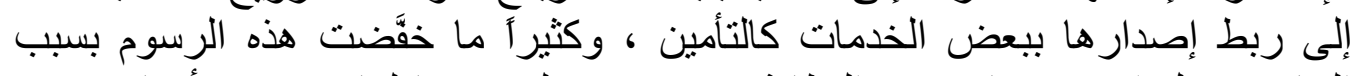

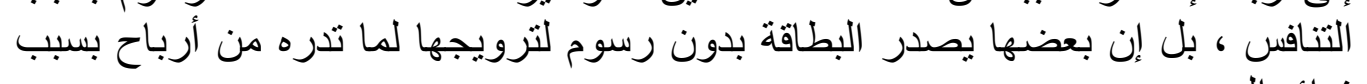

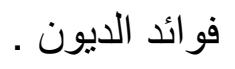

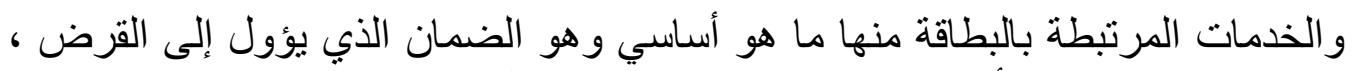

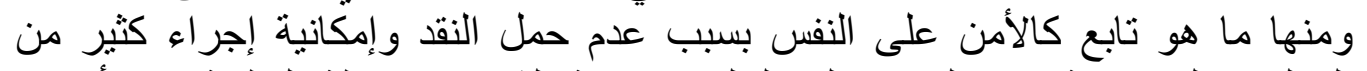

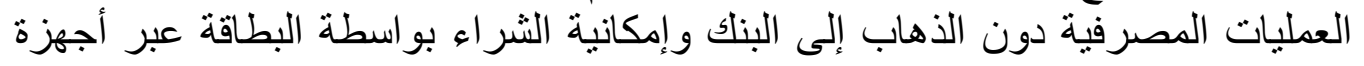
نقاط البيع . أطر اف البطاقة :

\section{البطاقة لها أطر اف متعددة :}

اـ المصدر - وهو البنأك - و الحامل - وهو العميل لاى هذا البنأك - و العلاقة بينهما تكون

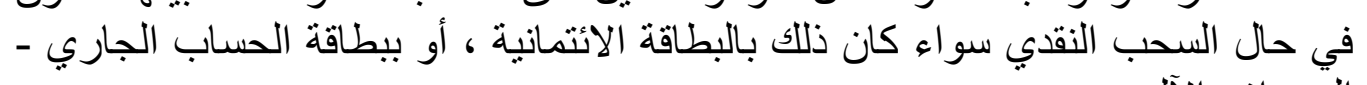
الصر اف الآلي-

r- المصدر و الحامل والقابل - وهو التاجر - و هذه العلاقة تكون في حال شراء السلع

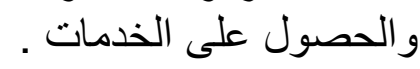

وقبل الخوض في حكم هذه الرسوم أثبير بإيجاز إلى التكييف الفقهي للعلاقة بين مصدر البطاقة وحاملها ، وأشهر الأقوال في ذلتك ما يلي :

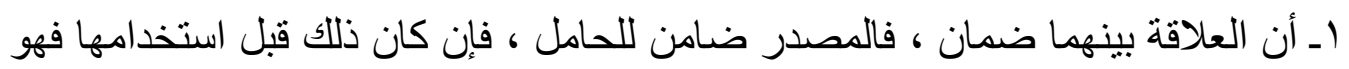

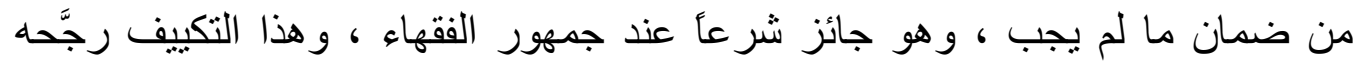
بعض الباحثين في المجمع الفقهي . لجن

ونوقش بأن هذا التكييف لا يشمل عملية السحب النقدي من مصدر البطاقة ، فهذه العملية

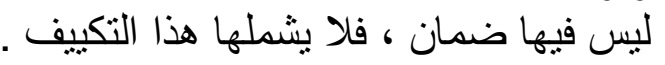


كما نوقش بأن الضمان يعني ضم ذمة إلى ذمة أخرى في المطالبة ، بحيث يسنطيع الدائن

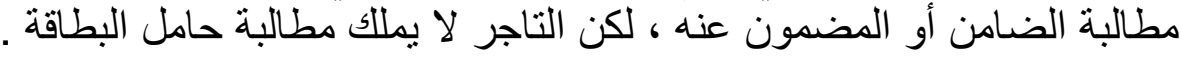

\section{وقد أبهيب ذلكبـا بـلي :}

أـ أن بعض الفقهاء أجاز في الضمان اشتراط بر اعة ذمة المضمون عنه ، وهو مذهب

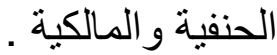

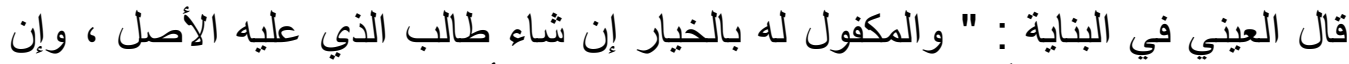

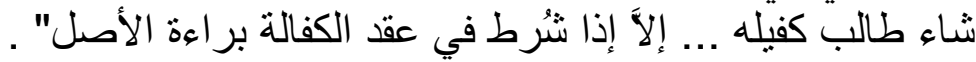

ب ـ أن جمعأ من الفقهاء برون أن الدَّين ينتقل إلى ذمة الضامن ، وليس للائن أن بطالب

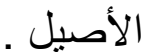

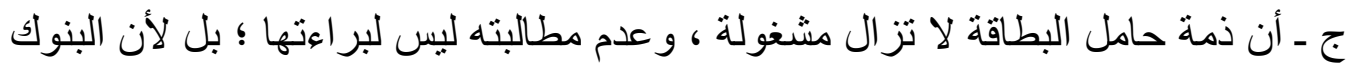

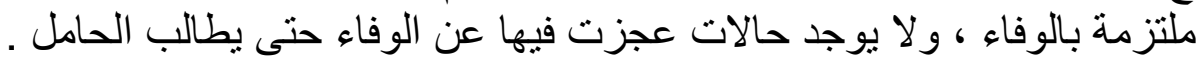

د ـ أن أهل الخبرة والاختصاص في أمور البطاقات لا ينفون حق التاجر في مطالبة

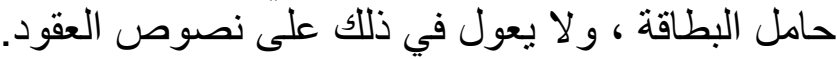

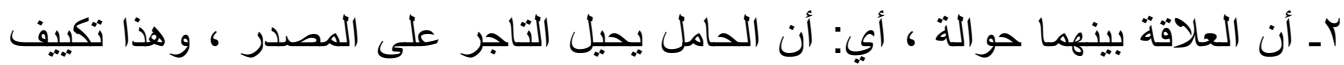

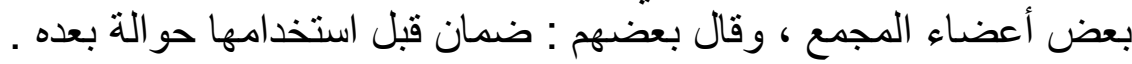

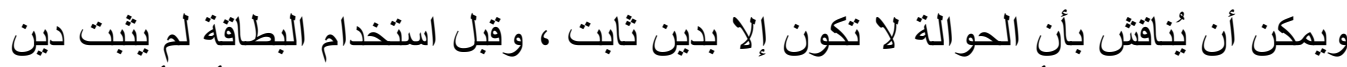

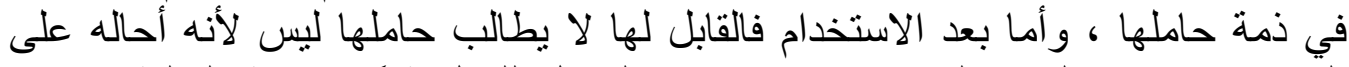

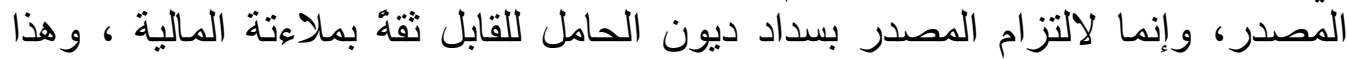

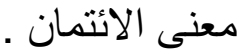

وقد أضاف بعضهم الوكالة إلى الضمان أو الحوالة ، لكن ذللك مناقش بأن حامل البطاقة لا يملك الدفع للتاجر ، و الوكالة لا تكون إلا في تصرف الوف مملوك للموكّل .

rـ أن العلاقة بينهما علاقة بين مقرض (مصدر البطاقة) ومقترض (حامل البطاقة) . ويمكن أن يُناقش بأن حامل البطاقة قد لا بيتخدمها ، و لا بد في القرض من دفئ مان مال ورد

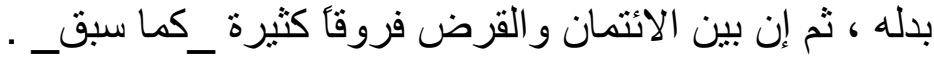

عـ أن العلاقة بينهما تتركب من عقدين : عقد الضمان وعقد القرض، فهي عقد ضمان

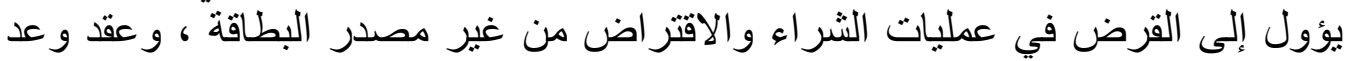

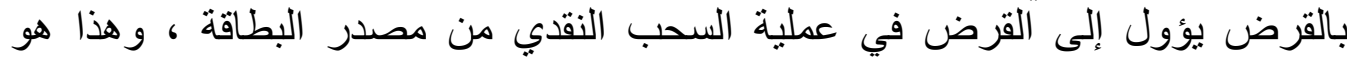




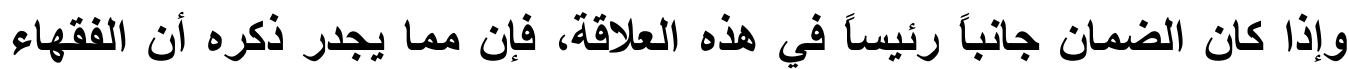

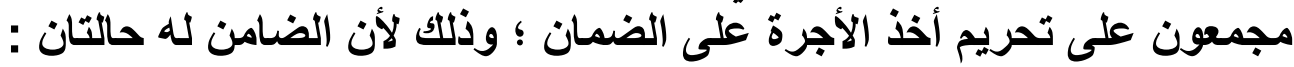
اـــ أن يدفع الدَّين نيابة عن المضمون عنه ثم يرجع إليه ، فيكون الأجر المشترط من

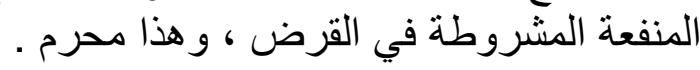

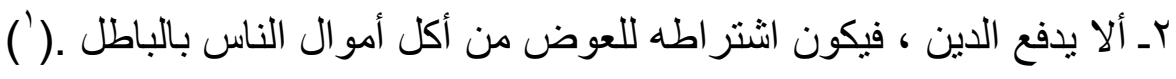
وقد اختلف المعاصرون في حكم أخذ الرسوم على إصدار البطاقة على أقوال : القول الأول : أنه يحرم أخذ الرسوم، وهذا رأي بعض أعضاء مجمع الققه كالدكتور

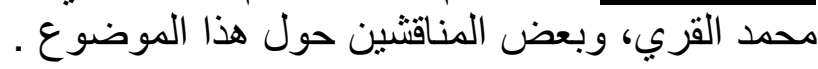

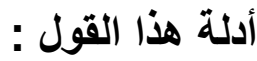

اــ أن العلاقة بين المصدر وحامل البطاقة ضمان ، وأخذ هذه الرسوم من أخذ الأجر

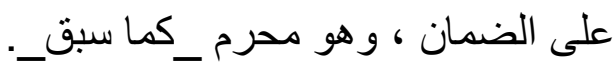

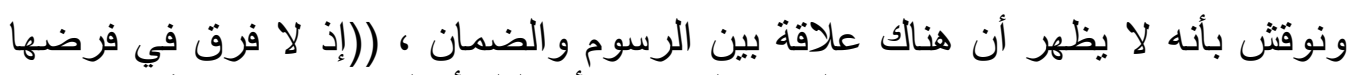
ومقدار ها بين ما إذا استخدها حاملها بمبالغ كثيرة أو قليلة أو لم يستخدمها بتاتأ)) .

بـــ أن الايتمان الذي يقدمه المصدر شبيه بالقرض ، فما يأخذه من رسوم فيه شبهة الربا

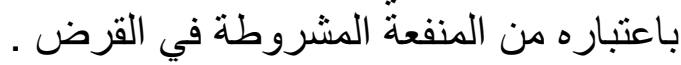

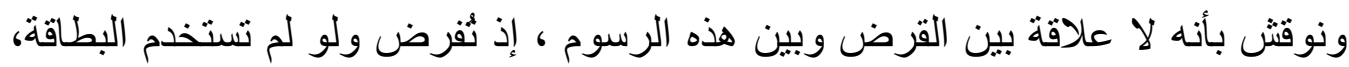

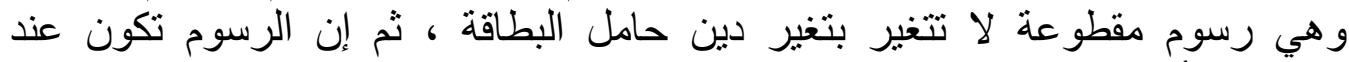
الإصدار، أي قبل وجود القرض الذي لا يحصل إلا باستخدام المشترك للبطاقة .

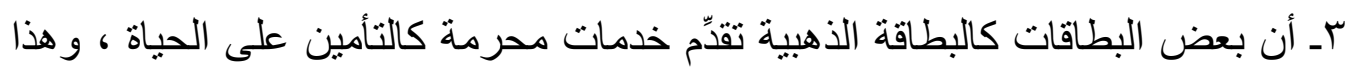

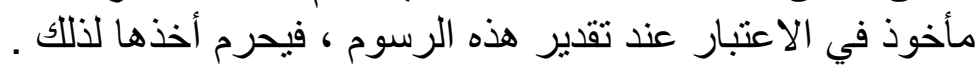

ونوقش ذلك بأنه يحرم الزيادة في الرسوم من أجل المنافع المحرمة، ولا يعني ذلك

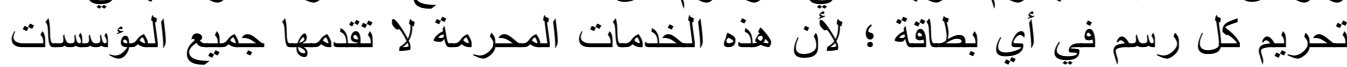

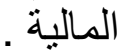

' - حكم البطاقات الإئتمانية ، أ. د محمد محروس المدرس الأعظمي - البحث مقدم إلى مجمع الفقه

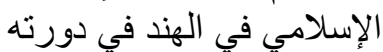

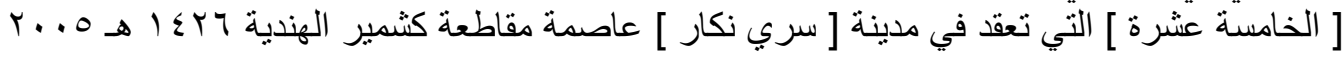




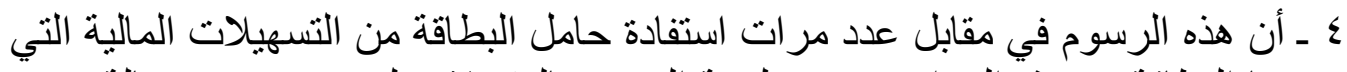

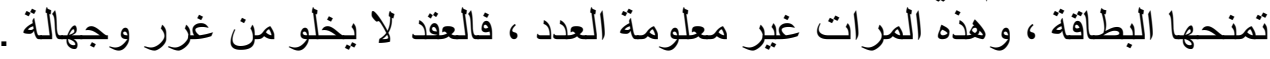
ويمكن أن يُناقش ذللك بأن الرسوم في مقابل تكاليف الإصدار ، و لا علاقة لها بعدد مرات

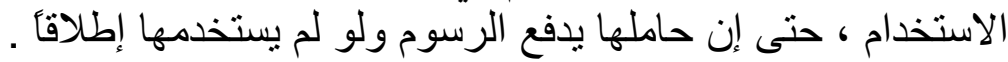

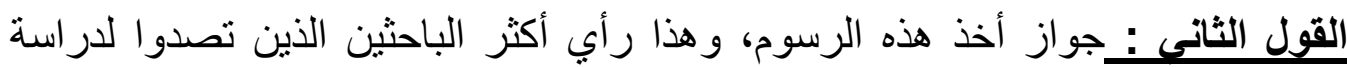

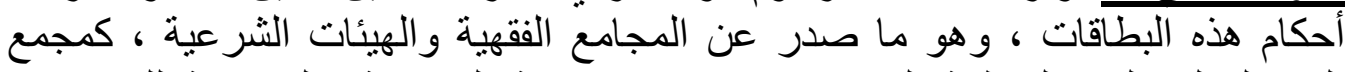

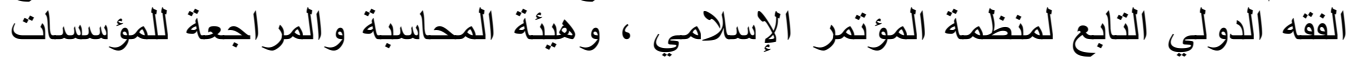

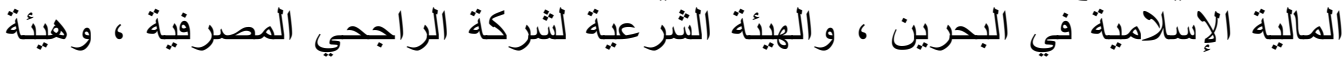

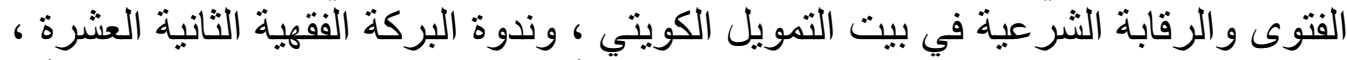

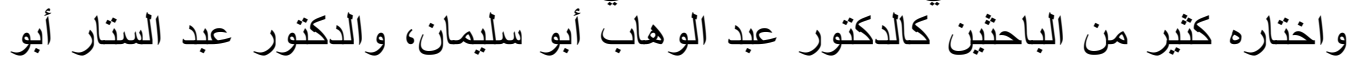

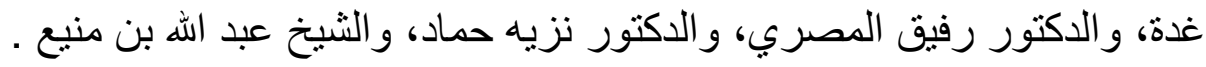

ومن أدلة هذا القول : 2 - 2

ا ـ أن هذه الرسوم في مقابل تقديم الخدمات المصرفية من شر اء السلع و الخدمات و وعملية

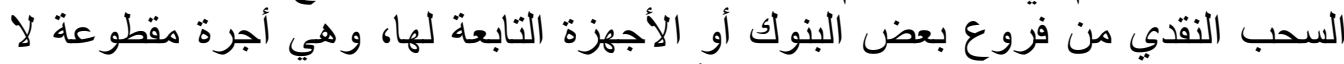
علاقة لها بمقدار دين حامل البطاقة ، فهي أجرة في مقابل عمل .

وقد يُقال: إن من أهم الخدمات المصرفية الائتمان القائم على الضمان ، فقد يكون فيها

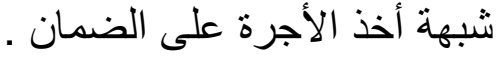

rـ أن إصدار هذه البطاقات تكلف البنك أعمالا إدارية كثيرة كتجهيز البطاقة وإرسال

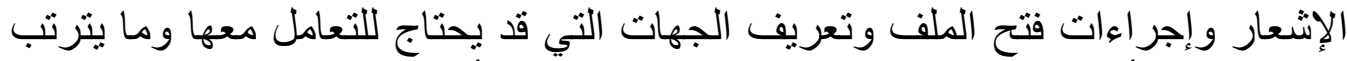

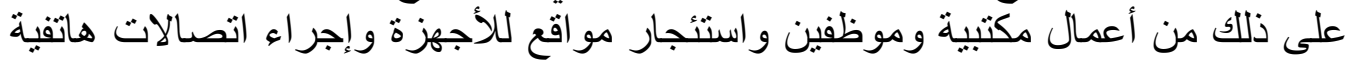
وتكاليف الاشتر الك في المنظمات ، فهذه الرسوم في مقابل هذه التكاليف .

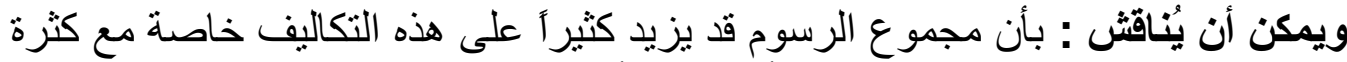

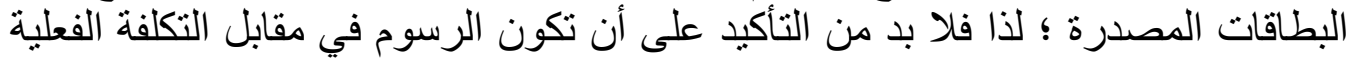

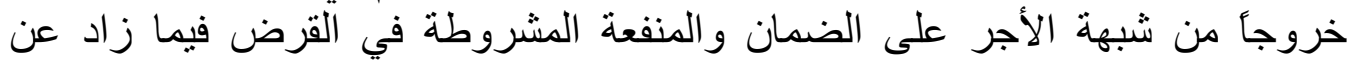
التكلفة .

rـ على تكييف العلاقة بين المصدر والحامل بأنها قرض ، فهذه الرسوم تعد من أجور

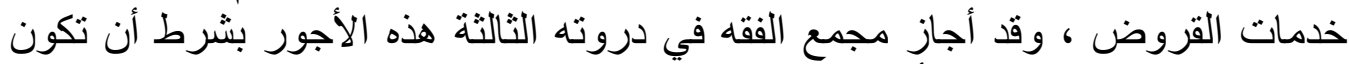

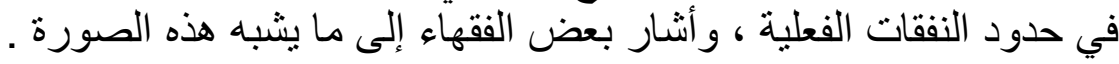
وقد سبق ما في تكبيف العلاقة على أنها قرض . 


\section{القول الثالث : التفصيل ، وذلك أن الرسوم على أقسام :}

أـ التكاليف و النفقات الفعلية ، وهذه جائزة إذا لم تكن تكاليف أمور محرمة كالتأمين وتم تقدير ها بدقة و عدل . ت التفات ب - رسوم الضمان ، وهذه لا يجوز أخذها لما مضى .

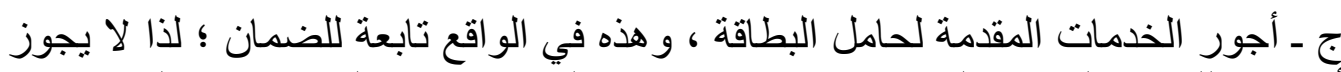

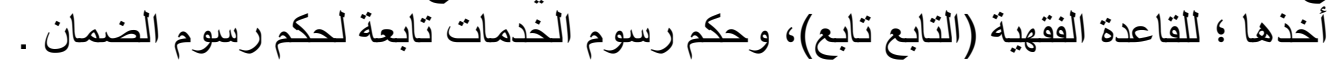

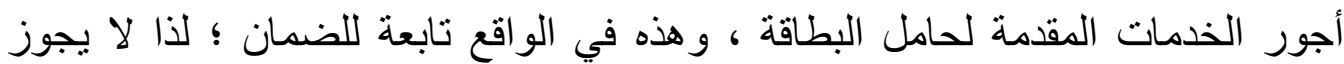

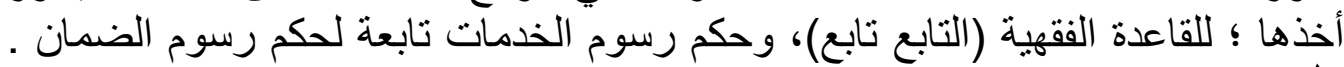

والقول هو الراجح الأخير عملا بقاعدة (اتباع ما لا يستقل بنفسه لما بستقل بنفسه) أو (

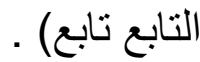

' - حكم البطاقات الإتتمانية ، أ. د محمد محروس المدرس الأعظمي ـ بتصرف ، بطاقة الانتمان

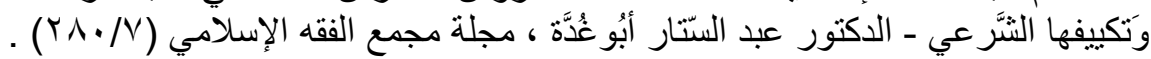




\title{
المبحث السادس
}

القاعدة السادسة : (كل عقد تقاعد عنه هقصوده بطل هن أصله )(')

\author{
الهطلب الأول
}

\section{صبيز القا عدة وبيان معناها}

وردت هذه القاعدة بألفاظ ، منها :

قول السرخسي : " إذا اعترض بعد العقد قبل حصول المقصود ما لو اقترن بالعقد كان

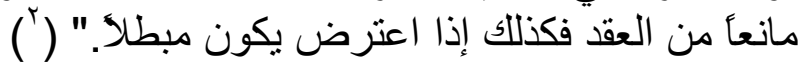

وقولهم : " كلّ عقد لا يفيد مقصوده يبطل ".)

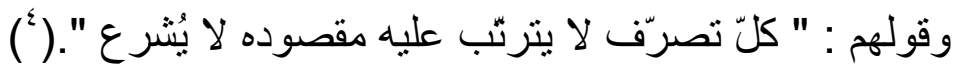

وقولهم : " كلّ تصرّف كان من العقود كالبيع أو غير العقود كالتّزير ات، وهو لا يحصل

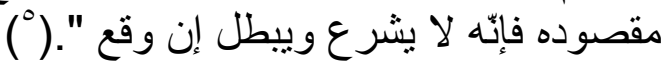

وقولهم : " كلّ لفظة كانت خالص لعقد حمل إطلاقها عليه، فإن وُصل بها ما ينافي

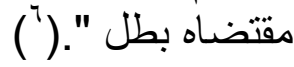

وقولهم : " اللفظ الموضوع للعقد إذا وجد معه ما ينافيه بطل؛ للتهافت "( ) وقولهم : "العبرة في العقود بالمقاصد و المعاني لا بالألفاظ و المباني".( )

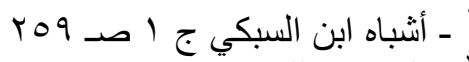

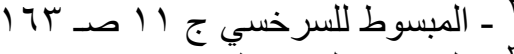

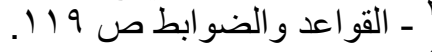

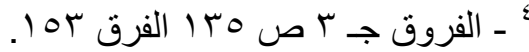

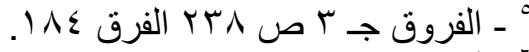

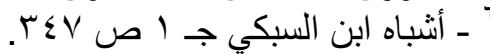

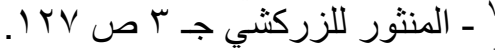

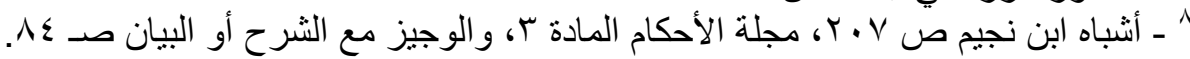




\section{معنـى القوا عد:}

العقود لصحتها شروط إذا فقد شرط منها لم يصح العقد، وهناك مو انع تمنع صحة العقد إنها

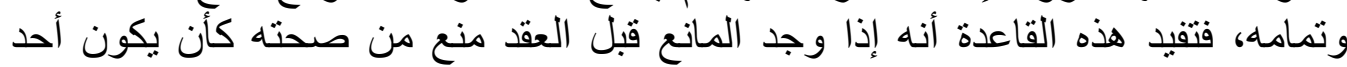
العاقدين محجوراً عليه، أو كأن يكون المبيع مينة أذو أو محرماً كالخمر.

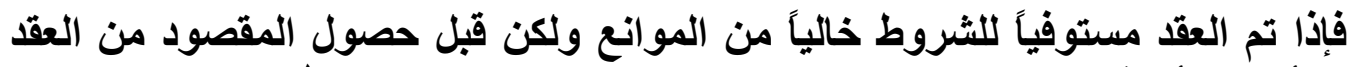

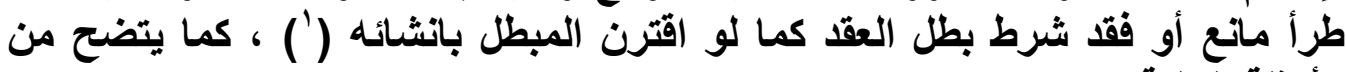

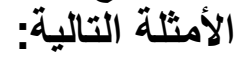

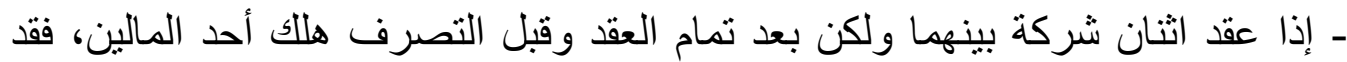

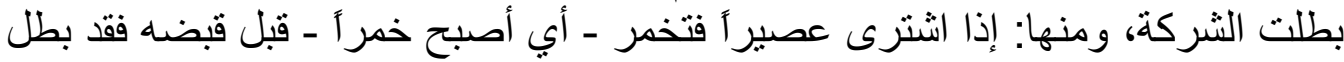
العقد.

- اشترى سلعة على أن لا يملكها، فالعقد باطل؛ لأنّ عقد البيع إنّما شرع لملك البدلين،

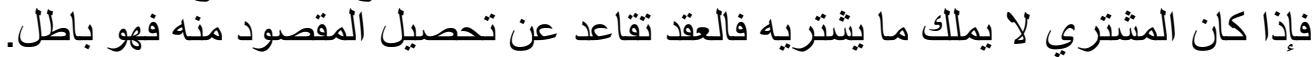

$$
\text { ـ عدم صحّ بيع الحرّ؛ لأنيّه ليس بمال. و لا يقع تحت اليد. }
$$

- إذا باع سلعة بشرط عدم انتفاع المشترى بها، فالعقد باطل؛ لأنّ مقصود عقد البيع حلّ الانتفاع بالبدلين. - إذا عقد اثنان شركة بينهما ولكن بعد تمام العقد وقبل التصرف هلك أحد المالين، فقد بطلت الثركة.

- إذا اشترى عصبرَ فتخمر ـ أي أصبح خمرَ - قبل قبضه فقد بطل العقد. - لا يثرع عقد البيع مع الجهالة والغرر ؛ لأن مقصوده تنمية المال وتحصيل مقاصد

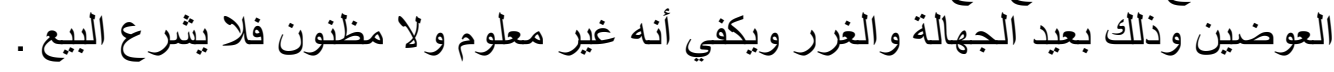




\section{المطلب الثنانبي}

\section{تطبيقات وتنفربيجات معاصرة ل1قاعدة}

1- مسألة كساد النقود الاصطلاحية :

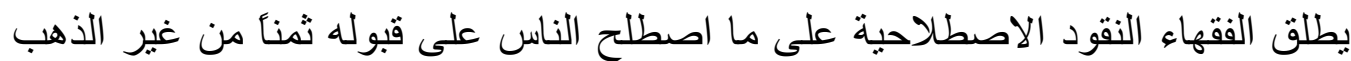

و الفضة كالفلوس و النقود الذهبية و الفضية الغالبة الغش. (' ) الكساد عند الفقهاء يكون بترك التعامل بالنقود في جميع البلاد.

وقد اختلف الفقهاء فيما يترتب على كساد النقود الاصطلاحية على ثلاثة أقوال: القول الأول: أنه إذا كسدت النقود الاصطلاحية فالواجب رد قيمتها. و هذا قول أبي يوسف، ومحمد بن الحسن من الحنفية، وهو قول عند المالكية، والمذهب

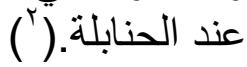
الققول الثانى: أنه إذا كسدت النقود الاصطلاحية فالواجب رد ما ثبت في الذمة في جميع

و هذا هو المشهور عند المالكية ، و المذهب عند الثافعية.(") القول الثالث: التفصيل، فإذا كسدت الاصطلاحية فهي إما أن تكون ثمنأ في بيع أو أجرة إنها

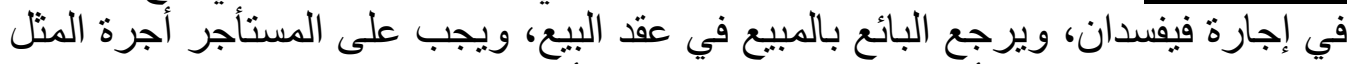

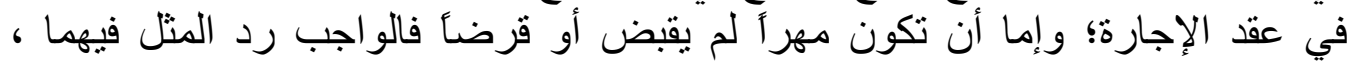

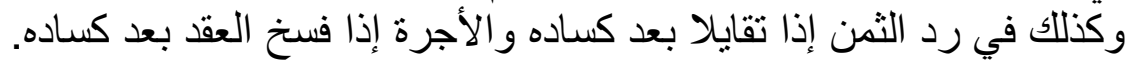

و هذا قول أبي حنيفة.(") ودن

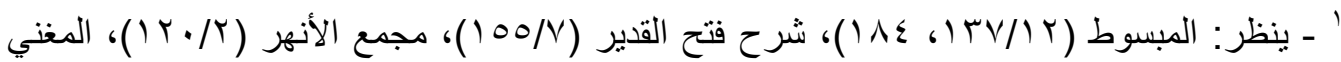

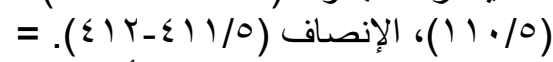

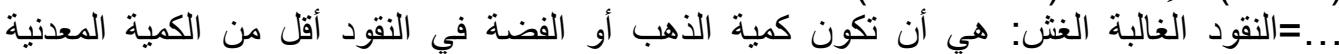

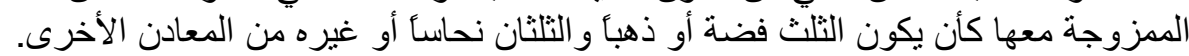

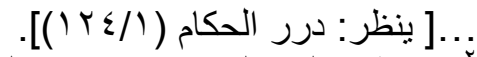

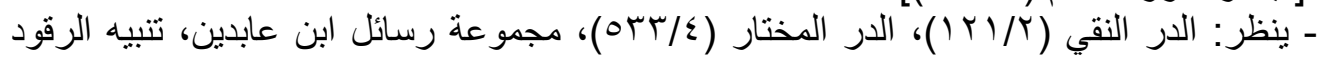

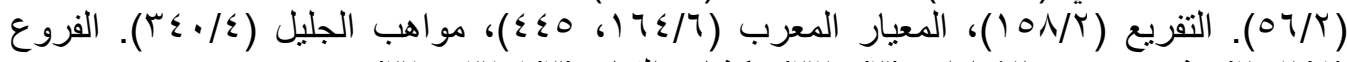

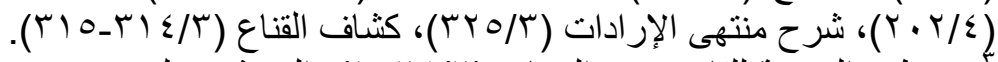

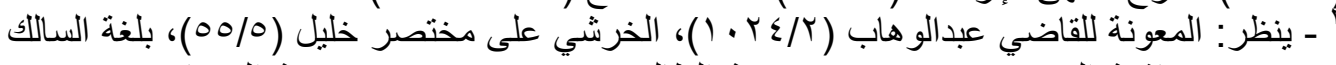

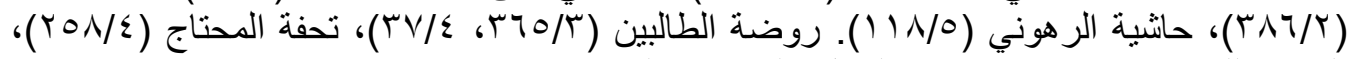

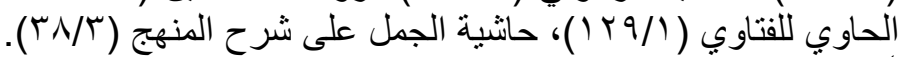

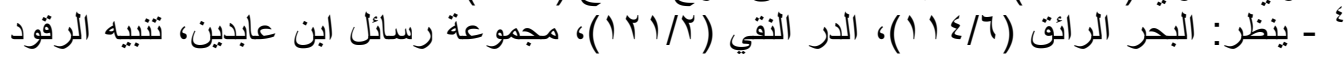




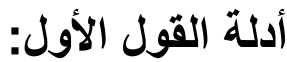

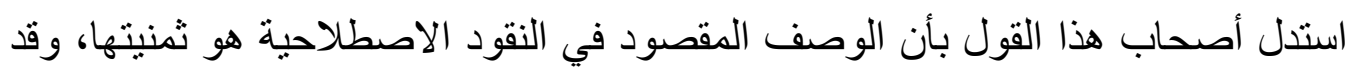

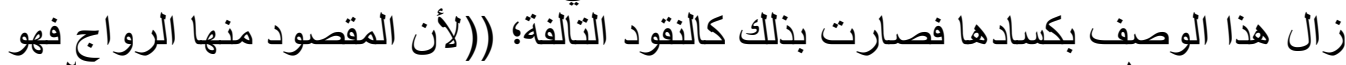

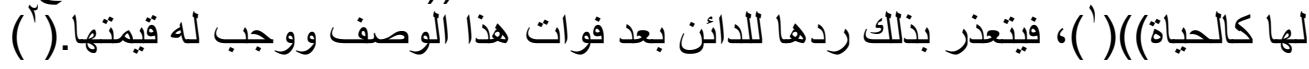
و على هذا فإن بذل هذه النقود الكاسدة التي لا نفع فيها ظلم لمستحقها؛ لأنه إنما قصد

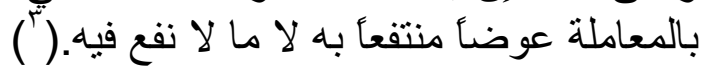

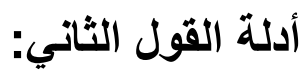
استال أصحاب هذا القول بما يأتي:

أولاًَ: أن الفلوس مثلية فيجب فيها رد المثل كسائر المثليات، والكساد لا يلغي هذا الوصف $\left({ }^{3}\right) \cdot \frac{1}{1}$

ثُانياً: أن كساد النقود الاصطلاحية الفلوس كجائحة نزلت بمال المستحق، فليس له إلا ما

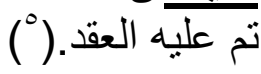

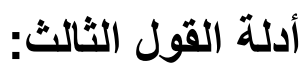

استدل أصحاب هذا القول بأن إيجاب القيمة في كساد النقود الاصطلاحية فيما إذا كان

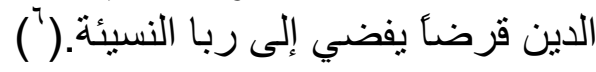
ولكل قول أدلة كثيرة غير التى ذكرت رأيت الاختصار و عدم التطويل بذكرها .

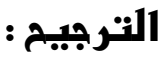

الذي يترجح من هذه الأقو ال هو القول الأول، وأن كساد النقود الاصطلاحية بعد التعامل

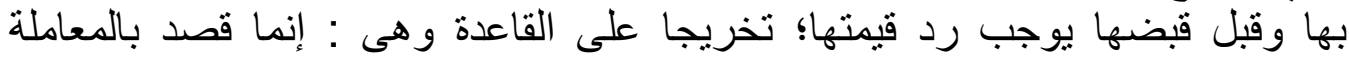
عوضأ منتفعأ به لا ما لا نفع فيه ، و هو نفس مدلول القاعدة المعنون بها و التى تقول : كل

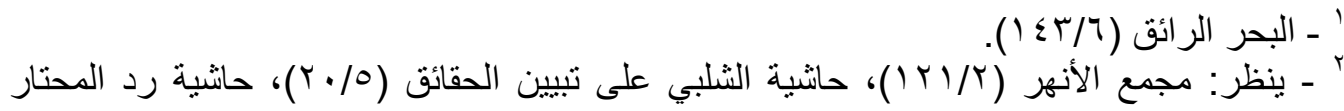
( $($ ( T人 6 $174 / 0)$

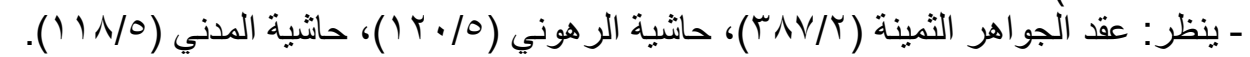

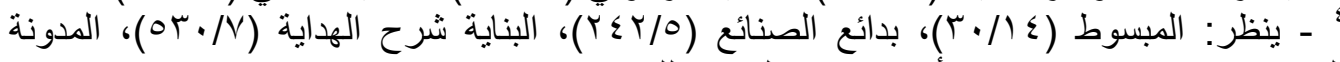

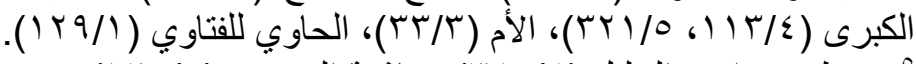

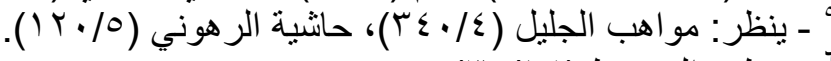




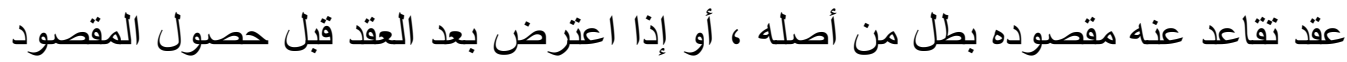

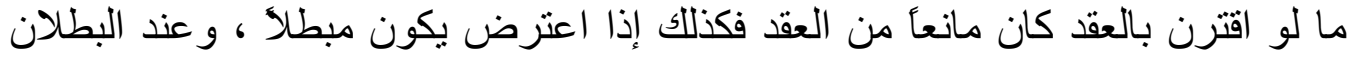

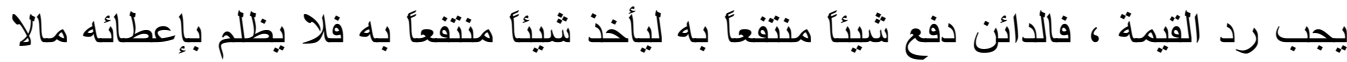
نفع فيه ، و الله أعلم بالصو ، فلاب دفع

\section{r- تغير النقود الاصطلاحية بالغلاء والرخص :}

اختلف الفقهاء فيما يترتب على غلاء النقود الاصطلاحية القلوس ورخصها بعد التعامل

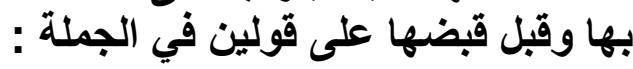

القول الأول: أنه إذا غلت النقود الاصطلاحية الفلوس أو رخصت بعد التعامل بها وقبل

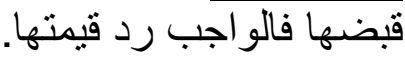

و هذا ما ذهب إليه أبو يوسف، و عليه الفتوى عند الحنفية، وقول عند الحنابلة اختاره شيخ

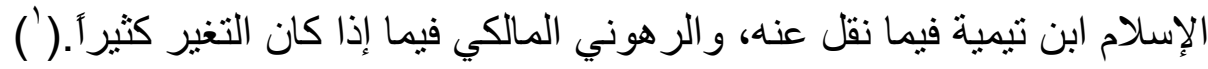
القول الثانى: أنه إذا غلت النقود الاصطلاحية الفلوس أو رخصت بعد التعامل بها وقبل

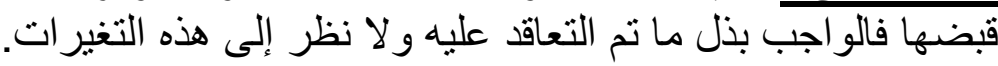

هذا ما ذهب إلبه أبو حنيفة وقال وقال به أبو يوسف أولا، وهو مشهور مذهب المالكية،

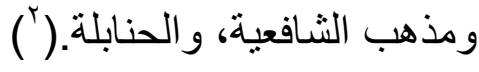

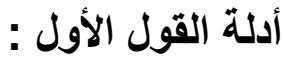

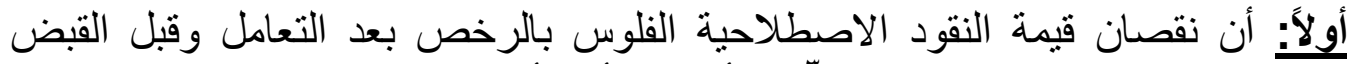

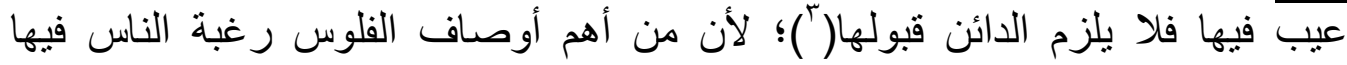

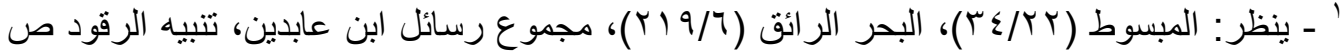

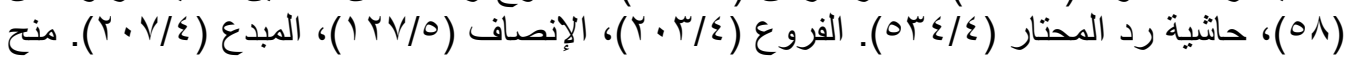

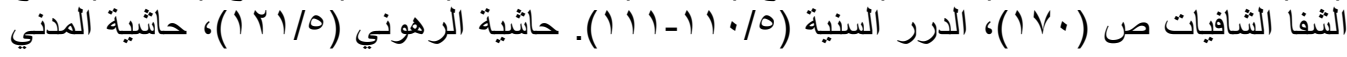
( (1) $1 / 0$ )

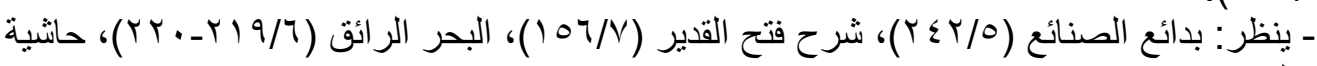

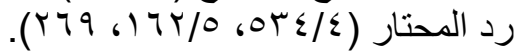

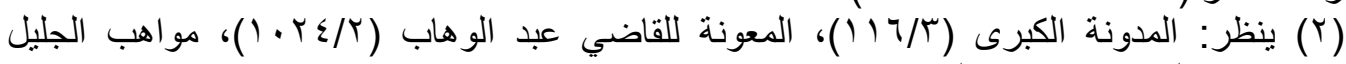
(Y)

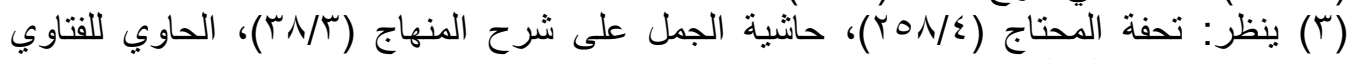

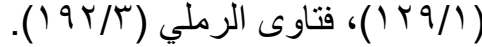

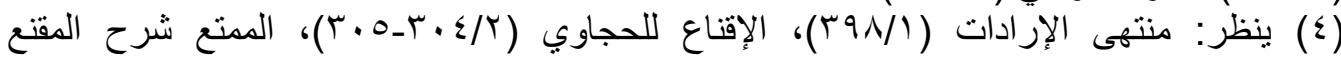
$(T \cdot N / \Gamma)$

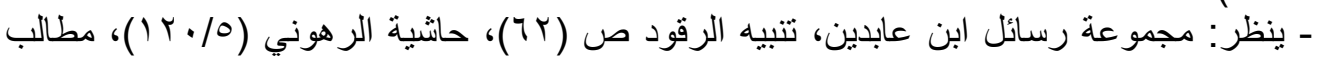

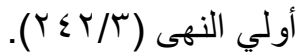


وقبولها وسيطا للتبادل وذلك مرتبط بقوتها الشرائية، وبرخصها يفوت هذا الوصف.

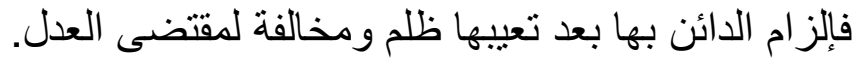

ثانياً: أن رد قيمة النقود الاصطلاحية الفلوس إذا غلت أو رخصت بعد التعامل بها وقبل

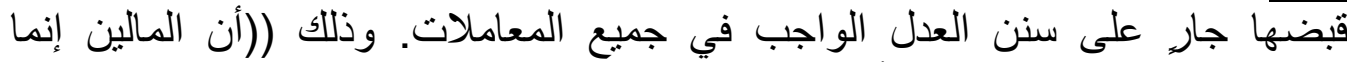

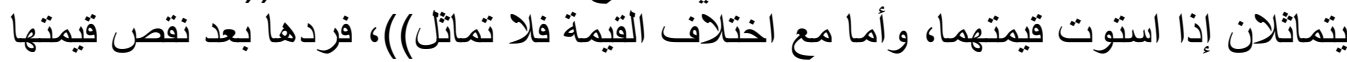

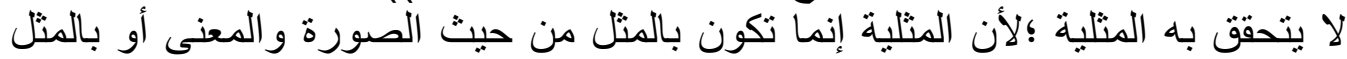

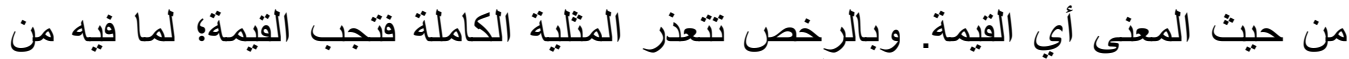

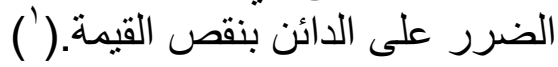

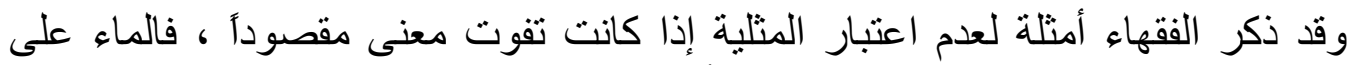

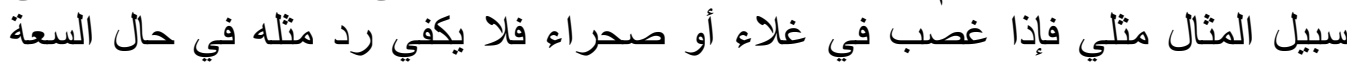

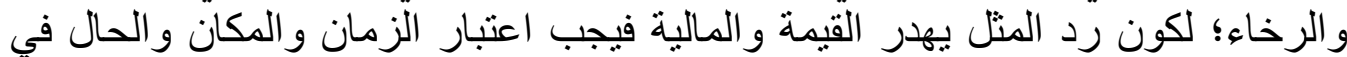

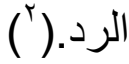

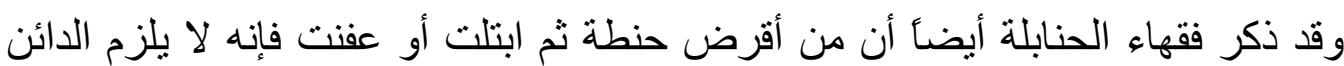

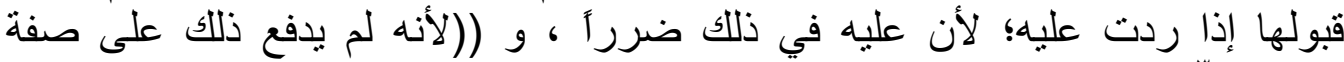

( )

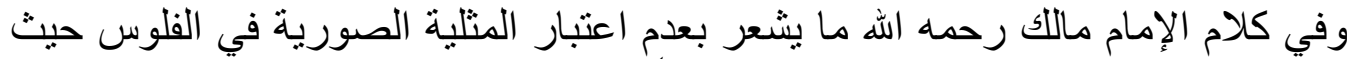

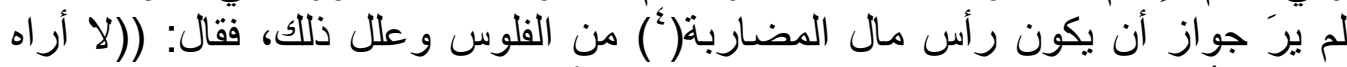

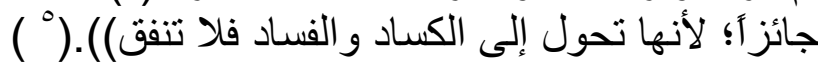

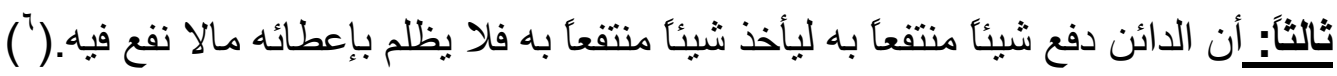

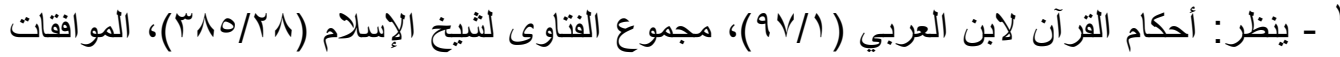

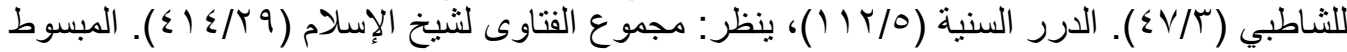

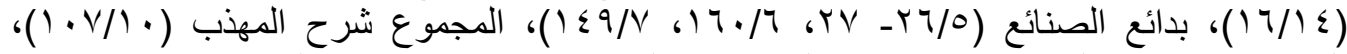

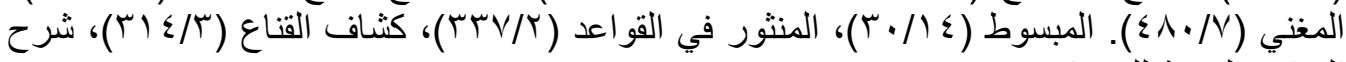

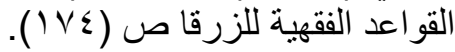

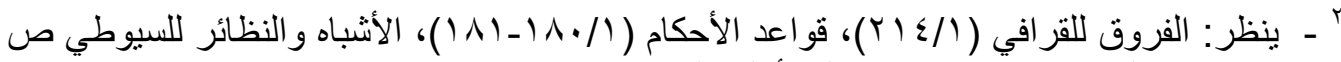
(O)

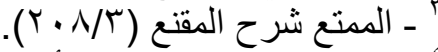
ع ـ ـ المضاربة: هي نوع المنع من أنواع الثركة في الربح يكون فيها رأس المال من طرف، و العمل و السعي

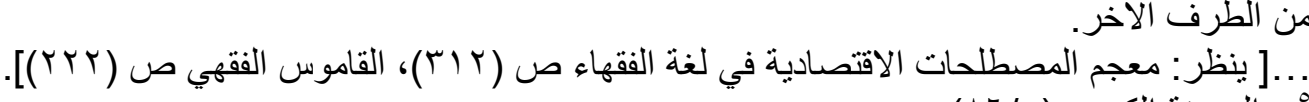


رابعاً: قياس رخص النقود الاصطلاحية الفلوس على كسادها بجامع أنهما نقصان في

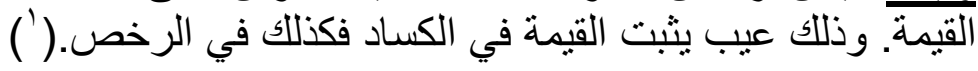

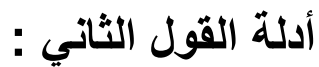

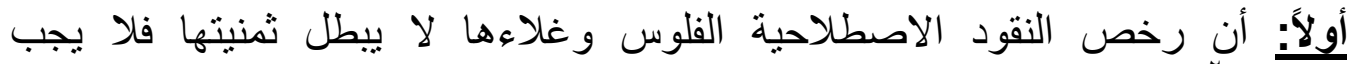

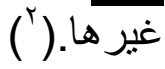

ثانياً: أن رخص النقود الاصطلاحية الفلوس وغلاءها لا بسقط عنها وصف المثلية فيجب

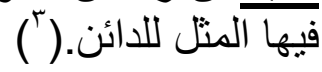

ثأثأثًا: أن إيجاب القيمة لرخص النقود الاصطلاحية الفلوس يفضي إلى فتح باب الربا(؛)؛ لأنه أعتياض أي عن الدين بأكثر منه.

ررابعاً: أن رخص النقود الاصطلاحية الفلوس و غلاءها لا يغير ما ثبت في الذمة كما لو

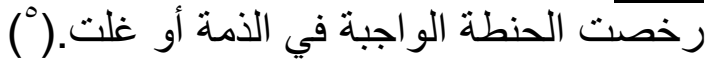

الترجيجم:

الأي يظهر بالنظر إلى ما استلال به كل فريق أن أقرب القولين إلى الصواب القول

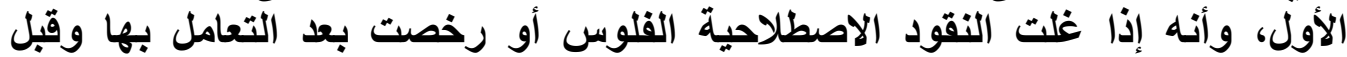

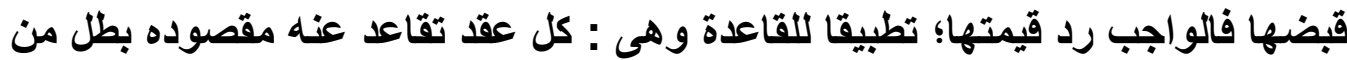

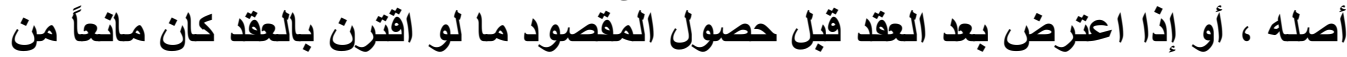

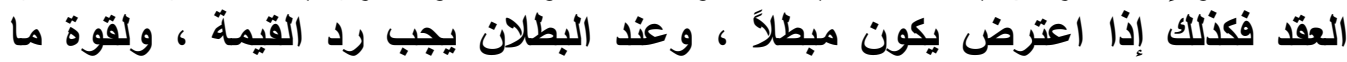

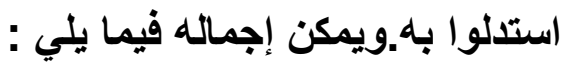
ـ أن نقصان قيمة النقود الاصطلاحية الفلوس بالرخص بعد التعامل وقبل القبض عيب لهب

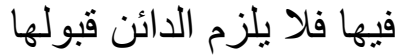
- أن الدائن دفع شيئًا منتفعأ به ليأخذ شيئً منتفعأ به فلا يظلم بإعطائه مالا نفع فيه ـ قياس رخص النقود الاصطلاحية الفلوس على كسادها بجامع أنهما نقصان في القيمة.

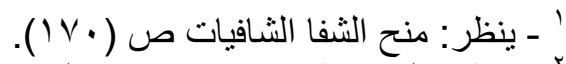

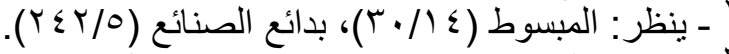

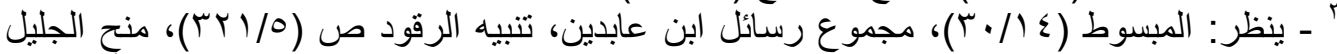

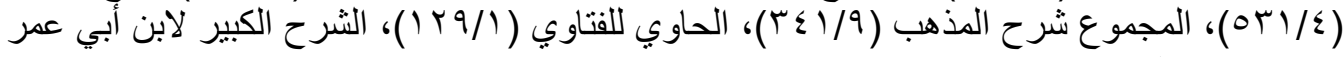

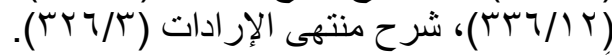

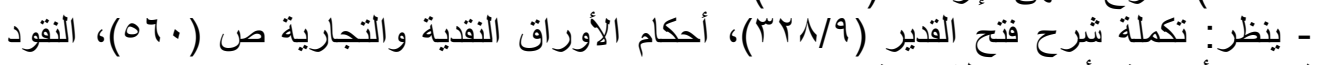

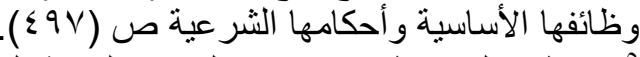

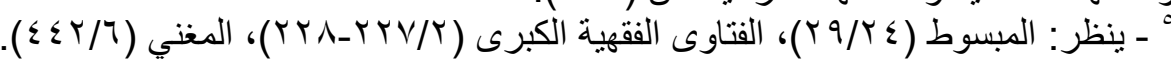




\section{الخاتمة}

الحمد الله والصلاة والسلام على رسول الله ، أما بعد :

فإني اختم هذا البحث المتواضع المجمل في هذه النقاط الموجزة :

1 - القواعد الفقهية : هي الأحكام الكلية التي ينطبق عليها جميع جزئياتها لتعرف أحكامها منها"، أو هي: صور كلية، تضم عددا من الصور الجزئية، التي تدخل تحت لتصن

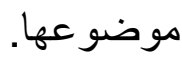

r ا - من العلوم المرتبطة بعلم الفقه، علم القو اعد الفقهية، فهو يضبط مسائل الفقه المتفرقة

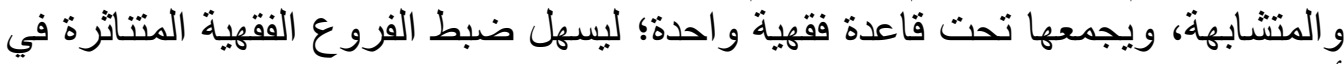

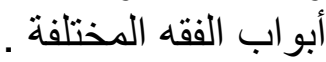

r ـ الراجح حجية القواعد الفقهية إذا كانت كلية دصدرها النص الثرعي ، وأما إذا كانت مذهبية فتصلح للترجيح كقر ائن وشو اهد للأحكام .

ـ ـ- ظهر جليا الاستفادة من القواعد الفقهية في تخريج المعاملات المعاصرة . 


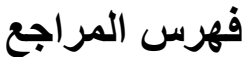

ا. . أحكام القرآن لابن العربي، المؤلف: محمد بن عبد الله الأندلسي الثهير بابن العربي، الناشر: دار الكتب الانب العلمية.

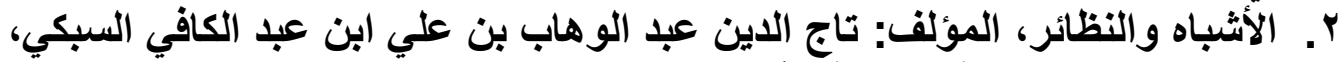

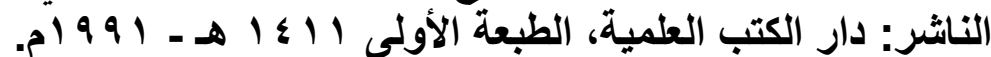

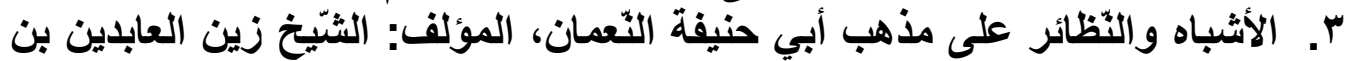

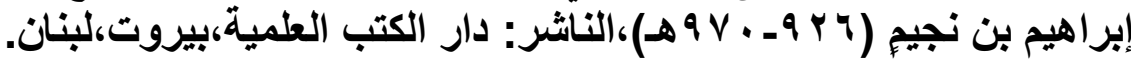

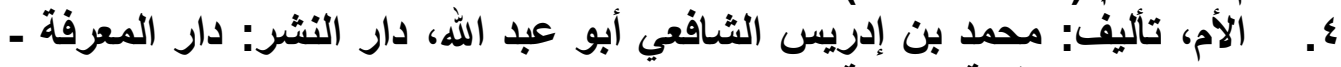

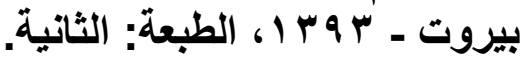

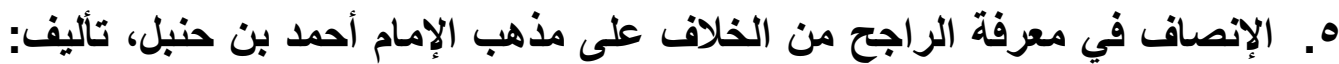

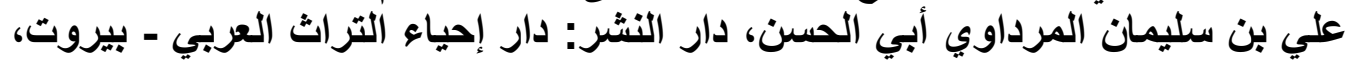
تحقيق: محمد حامد الفقي.

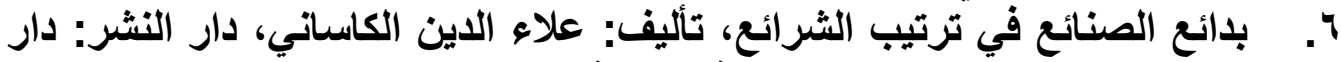

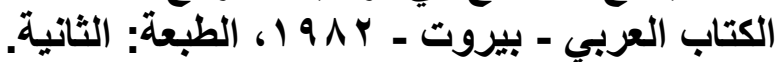
V

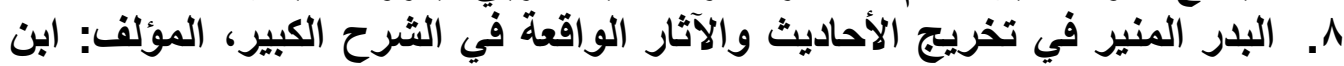

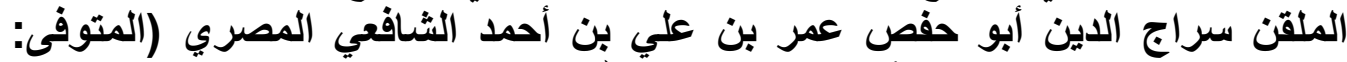

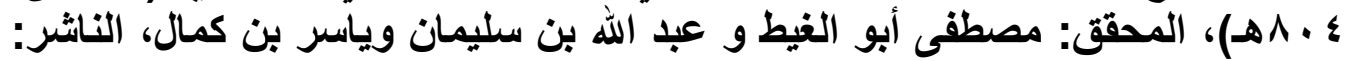

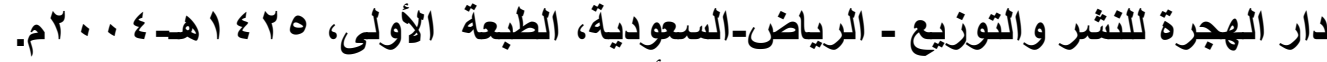

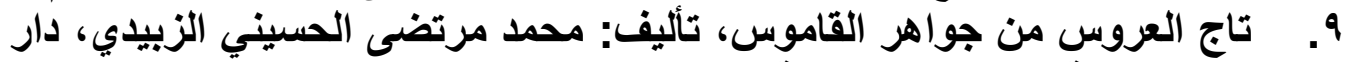

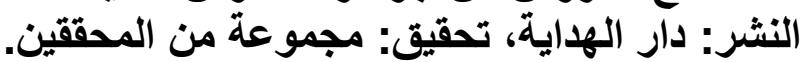

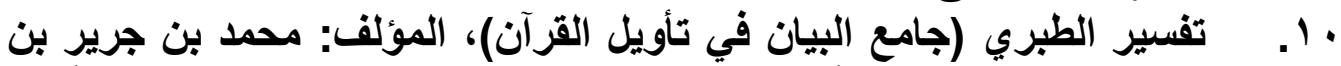

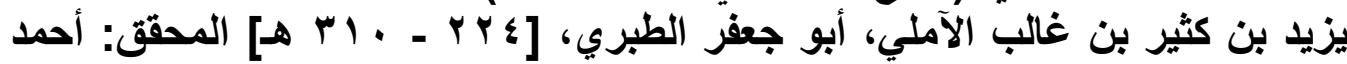

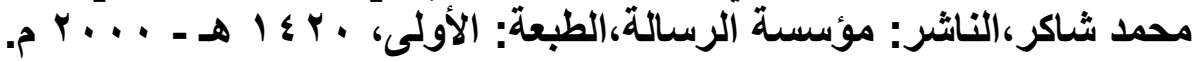

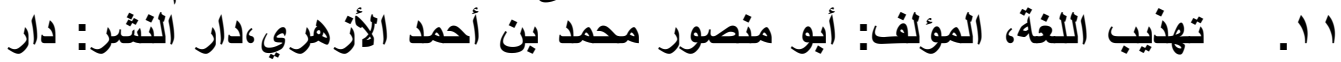

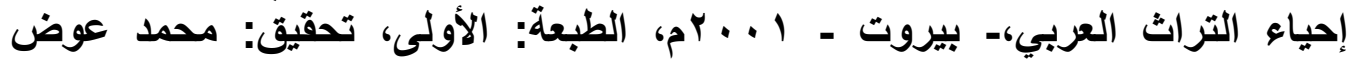
تيسير التحرير، المؤلف / محمد أمين ـ المعروف بأمير بادشاه / المتوفى المي

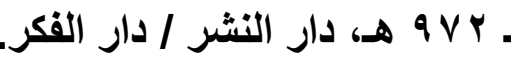

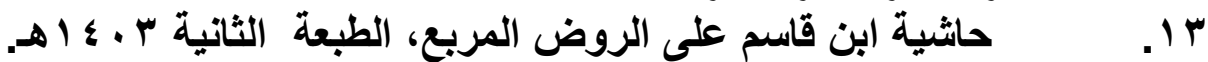

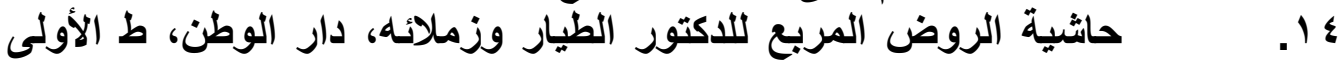
$\$ 1 \leq 17$

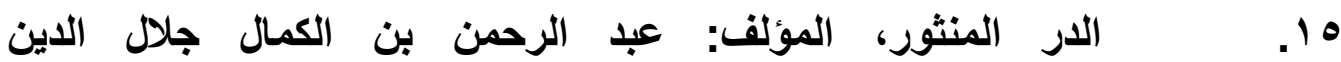

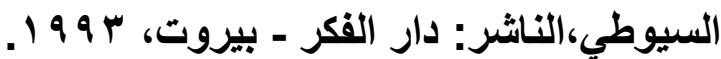

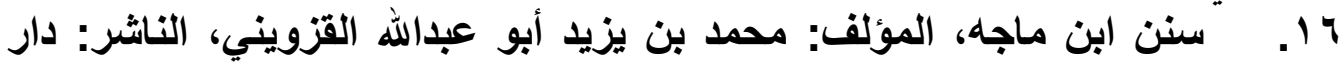
الفكر - بيروت، تحقيق: محمد فؤاد عبد الباقي، تعليق محمد فؤاد عبد البئ البياقي. 
IV

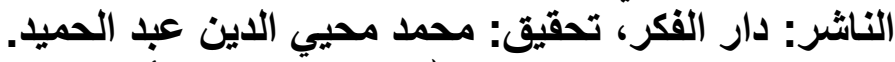

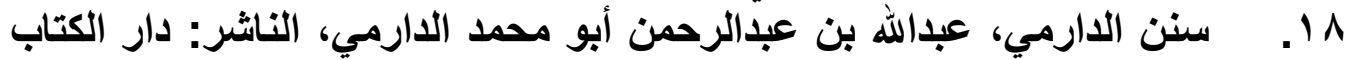

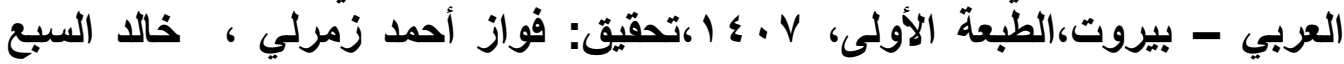
9 ا. . السنن الكبرى، المؤلف: أبو بكر أحمد بن الحسين بن علي البيهقي، الناشر:

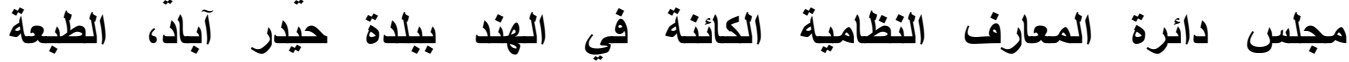

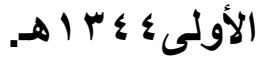

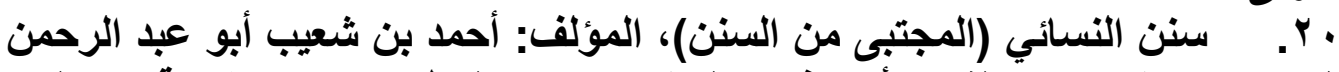

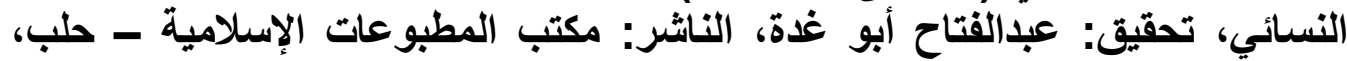

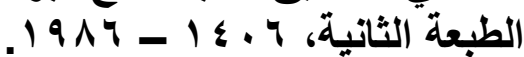

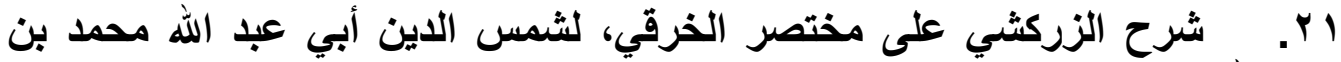

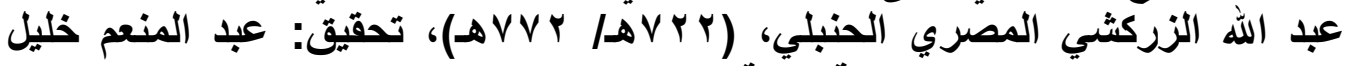

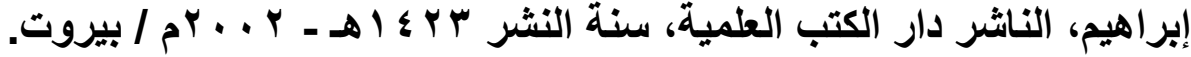

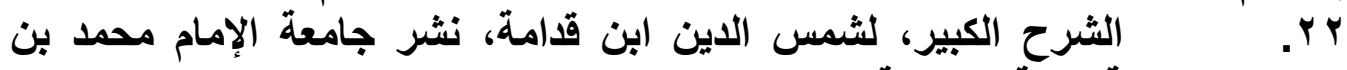
سعود الإسلامية، كلية الثريعة.

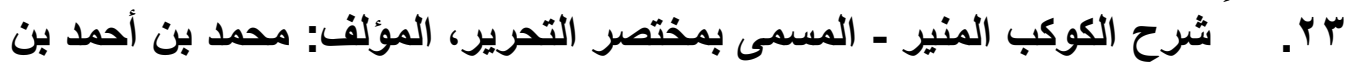

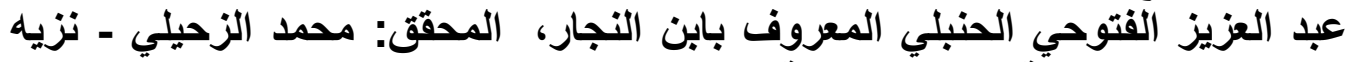

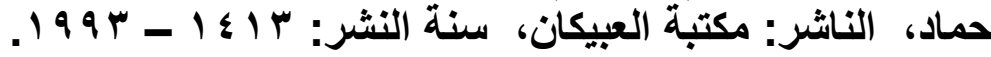

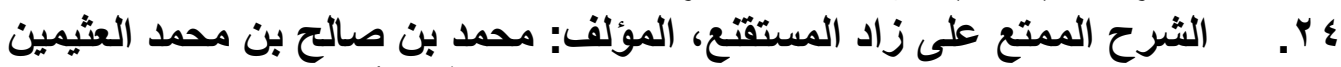

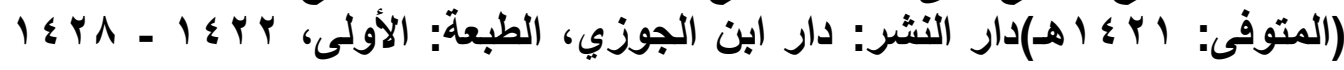

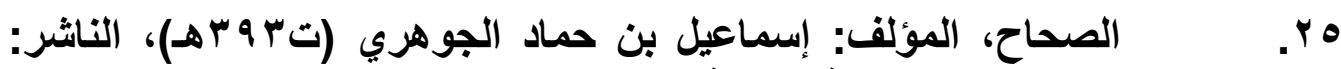

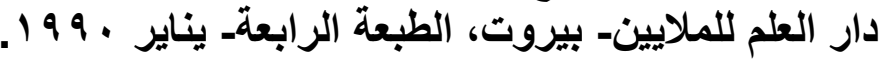

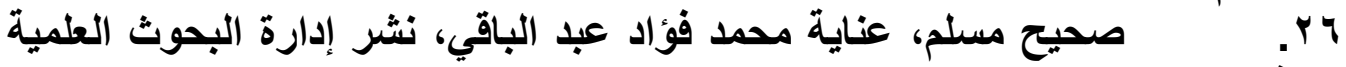

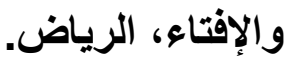

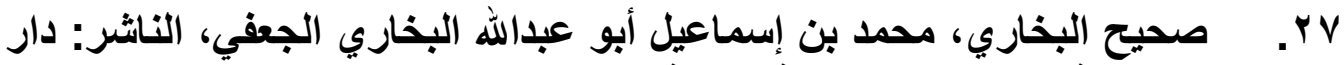

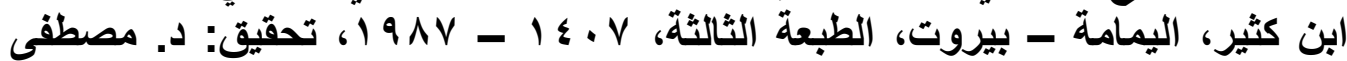

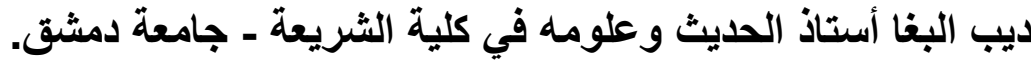

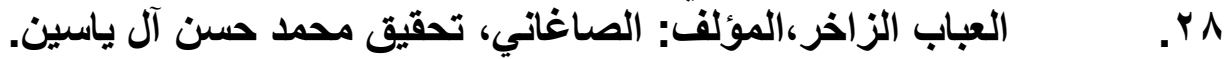

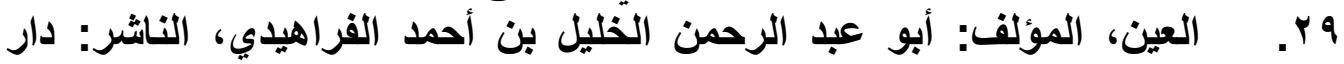

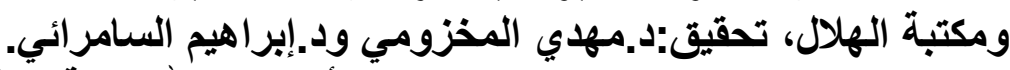

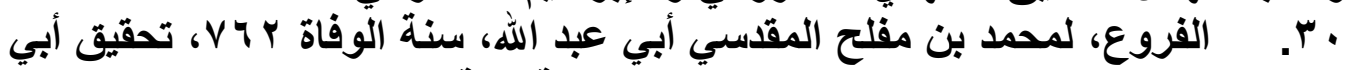

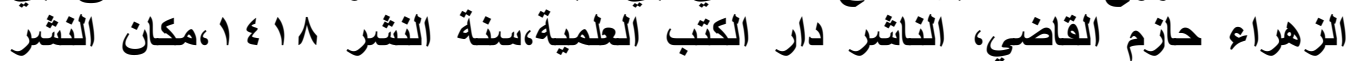
الفروق للقرافي، دار النشر: دار الكتب العلمية - بيروت. - 11 أهـ

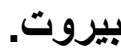




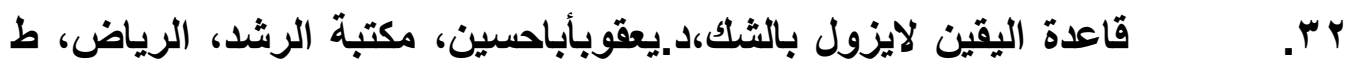

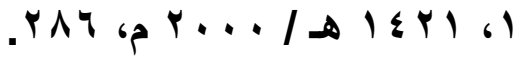

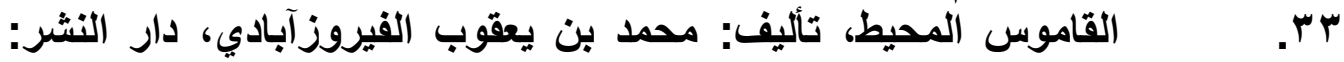
مؤسسة الرسالة - مبيروت.

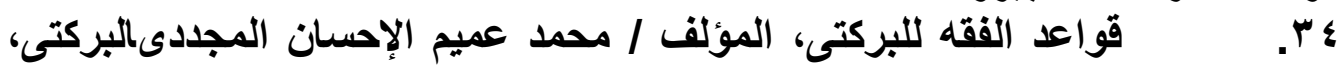

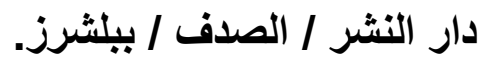

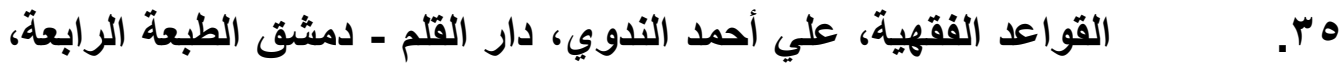
(

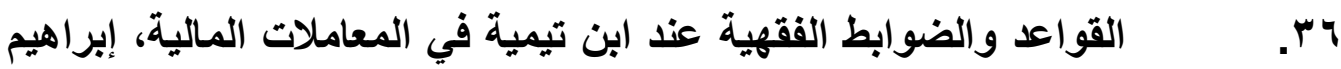

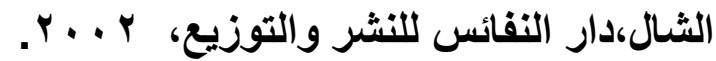
والهباة.rV

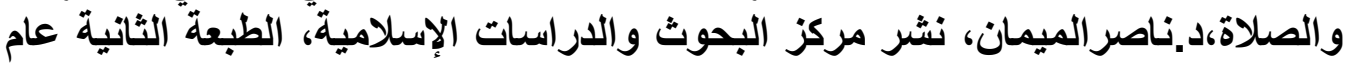
بr

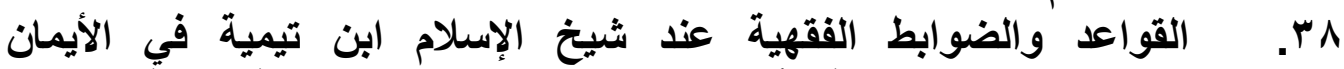

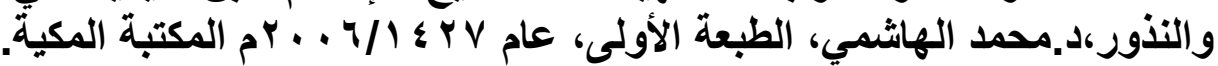

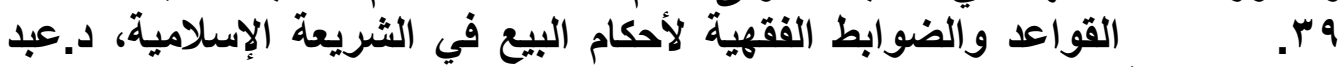

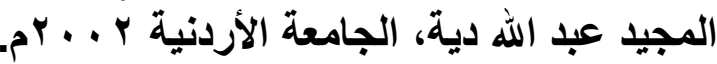

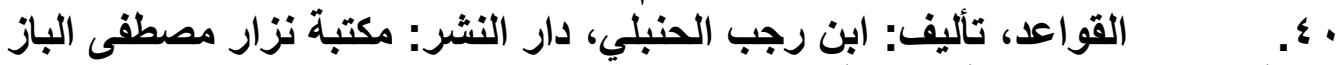
ـ مكة - 999 امو، الطبعة: الثانية.

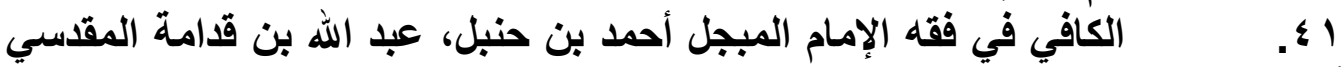

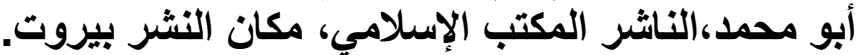

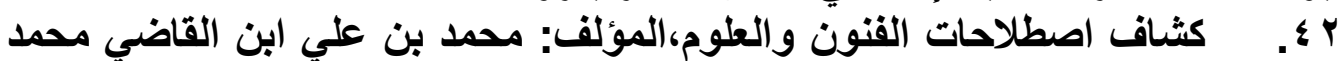

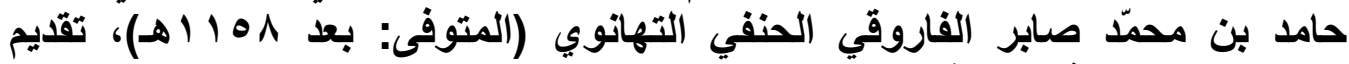

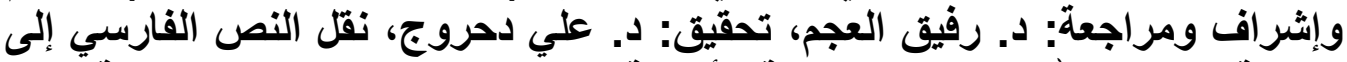

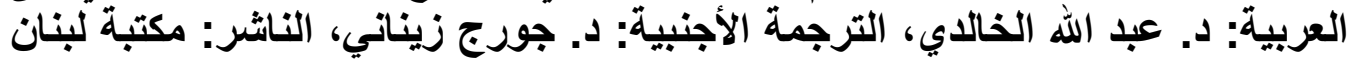

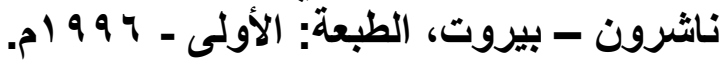

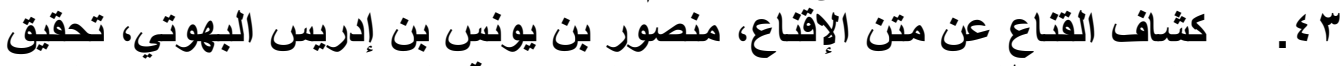

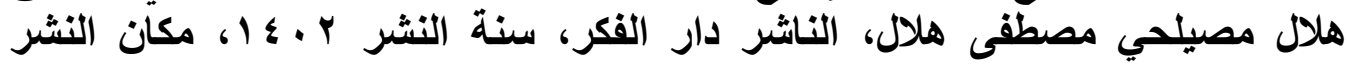

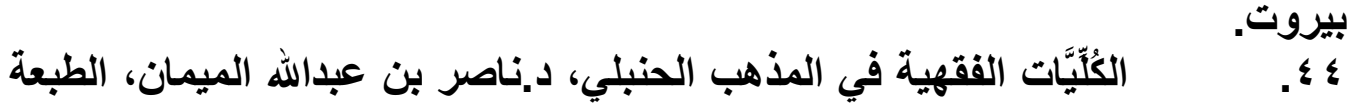
الأولى

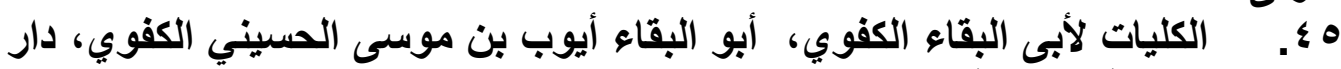

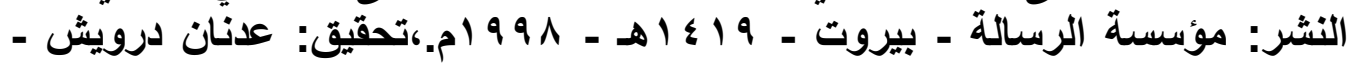

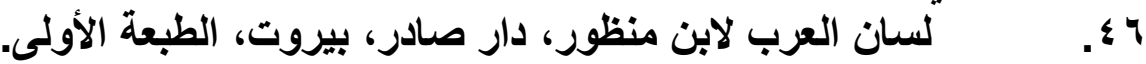
\&V الطبعة الأولى. 
^ء. مجموع فتاوى ابن تيمية، تحقيق: عبد الرحمن بن محمد بن قاسم، الناشر:

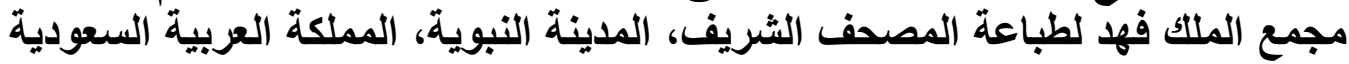
.

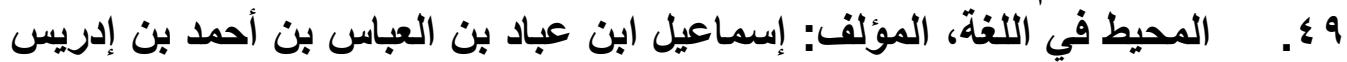

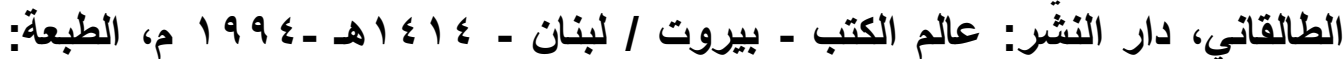
الأولى، تحقيق: الثيخ دار الثنر: محمد حسن آل ياسين.

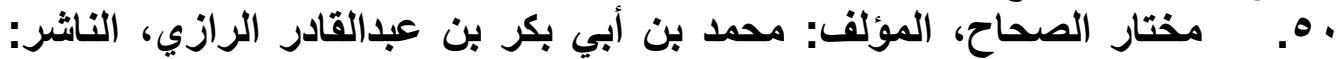
مكتبة لبنان ناشرون - بيروت، الطبعة طبعة جديدة،

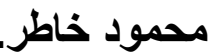

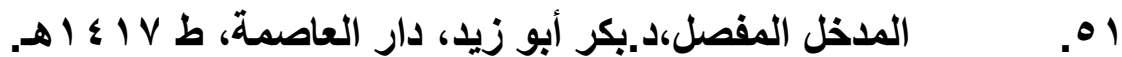

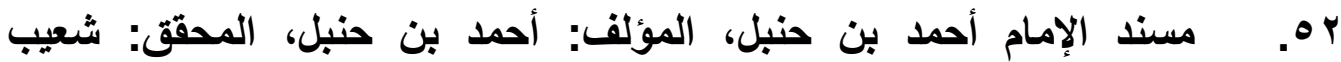

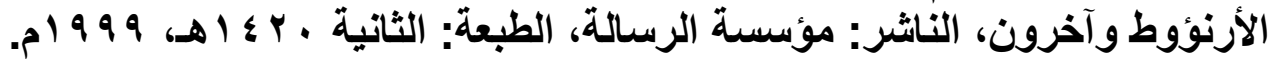

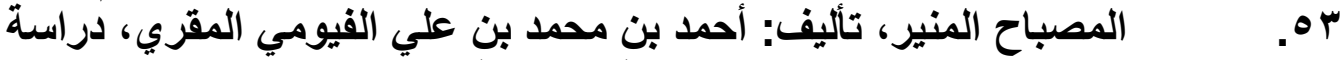

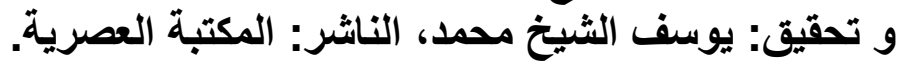

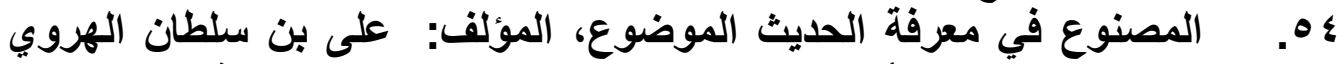

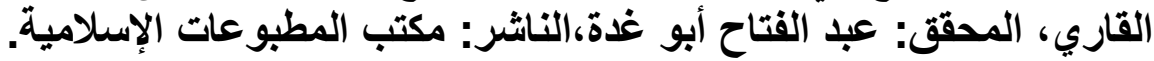

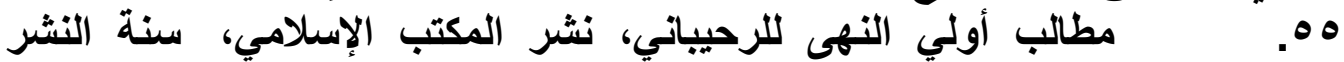

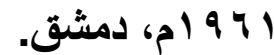

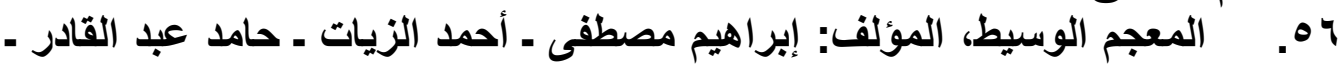

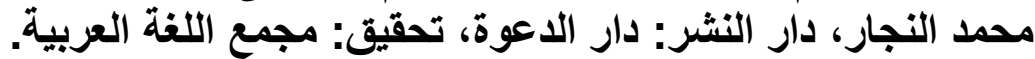

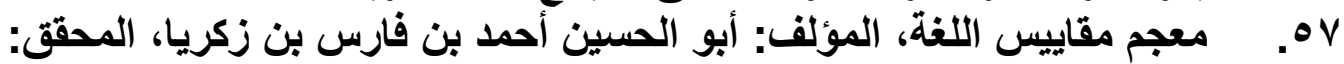

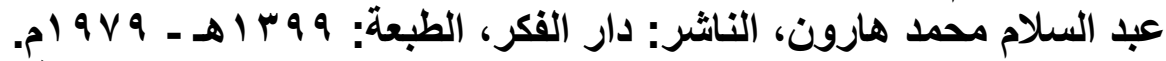

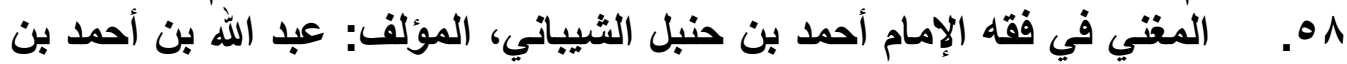

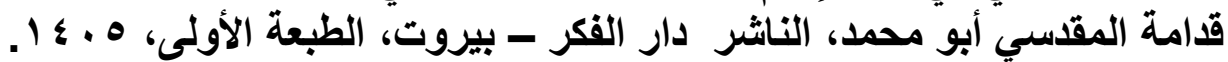

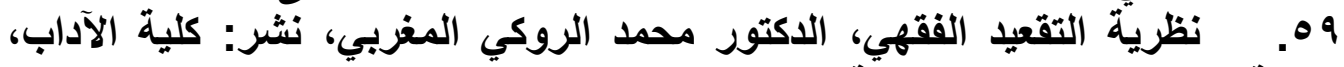

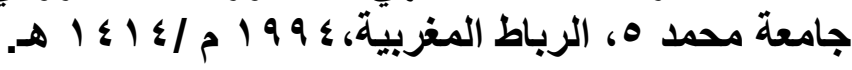

